Osvaldo Corrales

Eduardo Santa Cruz

\title{
LAS IMÁGENES DEL MIEDO DISCURSO TELEVISIVO Y SUJETO DELINCUENTE
}





\section{ÍNDICE}

6 PRESENTACIÓN

7 INTRODUCCIÓN

10 PRIMERA PARTE

EL PROBLEMA DE LA INVESTIGACIÓN Y SU ENTORNO

TEÓRICO Y EPISTEMOLÓGICO

\section{Capítulo 1}

11 LA RELACIÓN MEDIOS, DELINCUENCIA Y SEGURIDAD

CIUDADANA: CONSIDERACIONES PRELIMINARES

\section{Capítulo 2}

15 PRENSA, DISCURSO PERIODÍSTICO Y TELENOTICIARIO

\section{Capítulo 3}

26

\section{EL CONSTRUCCIONISMO SOCIAL: VERDAD,} REALIDAD Y MEDIOS DE COMUNICACIÓN

27 - El núcleo del programa Socioconstruccionista

28 - Socioconstruccionismo: tradición y novedad

31 - Construccionismo y medios de comunicación

34 - Medios de comunicación y relato factual

36 - Epílogo: Socioconstruccionismo, críticas y limitaciones

38 SEGUNDA PARTE

TELENOTICIARIOS, DISCURSO PERIODÍSTICO Y SUJETO DELINCUENTE: RESULTADOS DE INVESTIGACIÓN

\section{Capítulo 4}

39 LA INVESTIGACIÓN

39 - Diseño metodológico

40 - La dimensión cuantitativa: cobertura y presencia del sujeto delincuente en los telenoticiarios

58 - Comentarios finales 


\section{Capítulo 5}

63 LA REPRESENTACIÓN DEL SUJETO DELINCUENTE

63 - El Celotípico o Enajenado Mental Transitorio

64 - El Loco o Demente

65 - El Monstruo

66 - El joven delincuente

68 - Sujeto delincuente: rasgos modales y rasgos basales

\section{Capítulo 6}

71 OPERACIONES DISCURSIVAS: FICCIÓN Y REALIDAD EN EL TELENOTICIARIO

73 - El caso de Canal 13

77 - El caso de Televisión Nacional de Chile

80 - El caso de Chilevisión

85 - El caso de Megavisión 
"...Informar sigue significando dar forma. Pues el diario, el noticiero de radio o el de televisión son hoy-como en otros tiempos lo fueron los mitos- el discurso que cotidianamente se hace cargo del desorden del mundo, y nos ordena el caos en que nos sumerge la diversidad de lo que sucede al otorgar un sentido a los acontecimientos"

(Jesús Martín Barbero y Germán Rey) 


\section{PRESENTACION}

El texto que presentamos a continuación es producto del Proyecto SOC 06/ 19-2, de la Vicerrectoría de Investigación y Desarrollo de la Universidad de Chile, el cual fue realizado en el marco de las actividades académicas del Centro de Estudios de la Comunicación perteneciente al Instituto de Comunicación e Imagen de esta casa de estudios superiores.

Dicho proyecto estuvo a cargo de los investigadores y académicos Eduardo Santa Cruz y Osvaldo Corrales quienes contaron, para su fase de elaboración, con la asistencia de Claudio Salinas y Hans Stange y, posteriormente, durante la fase de recopilación y análisis cuantitativo de los datos, con la de RenéJara e Ignacio Guajardo, siendo de su autoría el capítulo correspondiente a aquello.

Si bien su presentación original se realizó durante el año 2006, su ejecución ocurrió entre los años 2007 (fecha en que se recogió la muestra posteriormente analizada), 2008 y principios de 2009, correspondiendo el presente texto al resultado del trabajo teórico, analítico y de discusión realizado durante ese período.

El objetivo último de la investigación que aquí se reseña fue contribuir a la reflexión crítica en torno al rol que juegan los medios de comunicación en el Chile contemporáneo y, muy especialmente, al papel que le cabe a los telenoticieros en la forma en que constituimos nuestra comprensión de lo social. Para ello, el trabajo se vale del análisis de un caso ejemplar: el de la representación del sujeto delincuente al interior de dicho género televisivo. La elección de este caso no es azarosa, se trata de una figura que ha adquirido una importancia cada día mayor dentro del discurso político y mediático del país y en torno a la cual se ha constituido uno de los principales antagonismos actualmente vigentes, dando fundamento a la constitución de una sociedad policial, basada en la desconfianza y el miedo al otro y articulada en torno a la, ya no tan nueva, ideología de la seguridad ciudadana.

La valoración respecto del cumplimiento de ese objetivo corresponde al lector quien, como siempre, tiene la última palabra.

Santiago, Julio 2010. 


\section{INTRODUCCIÓN}

Los medios de comunicación representan uno de los más importantes dispositivos de producción y reproducción de material simbólico al interior de las sociedades contemporáneas, postindustriales y tardomodernas. En la llamada era de la información y las comunicaciones, los medios masivos, y entre ellos especialmente la televisión, juegan un importante rol en la comprensión que desarrollamos del mundo que nos rodea, en las explicaciones que formulamos para los hechos de la vida social y en las imágenes que de ella nos formamos.

Aunque la discusión en torno a los efectos de los medios tiene una larga tradición (Lasswell publicó su clásico estudio Propaganda Techniques in the World War en 1927) y hace ya mucho tiempo que se abandonó la idea que los medios de comunicación eran agentes todopoderosos capaces de condicionar de un modo absoluto el comportamiento del público (de hecho, en la década de los 60' autores como Joseph Klapper (1974) llegaron a plantear que los medios de comunicación eran incapaces de producir efectos relevantes por sí mismos), la moderna visión que sobre ellos existe reconoce que, aunque en el corto plazo y considerados individualmente los efectos de sus mensajes no necesariamente responden a las expectativas que sobre ellos se depositan, evaluados desde una perspectiva global y de largo plazo, sus efectos acumulativos en el nivel sociocultural sí podrían ser considerados como relevantes. Esta es la hipótesis desde la que van a partir planteamientos como el de McCombs y Shaw (1972), quienes trabajan la idea de "agenda setting" (que considera que el principal efecto de los medios de comunicación es el establecimiento de la agenda de los temas socialmente prioritarios) o el de Noelle-Neumann (1995), que plantea conceptos como los de "clima de opinión" y "espiral de silencio".

En esa misma línea, el psicólogo social francés Serge Moscovici (1971) considera a los medios de comunicación como una de las principales fuentes en el proceso de constitución de esa forma de conocimiento cotidiano que es el sentido común y que él conceptualiza teóricamente bajo la denominación de Representación Social.

Evidentemente, en la constitución de dichas representaciones no todos los medios de comunicación tienen la misma eficacia simbólica; ésta se modificará de acuerdo a variables como la masividad de su cobertura y su credibilidad frente al público. A este respecto, un estudio realizado por el Consejo Nacional de Televisión (2003) determinó que el medio diariamente más consumido por los chilenos en Santiago durante el año 2002 fue la televisión, con un $85 \%$; seguida por la radio, con un $70 \%$ y luego por la televisión de pago, con un 64\%; apareciendo sólo en cuarto lugar y a gran distancia la prensa escrita con un $26 \%$. Por otra parte, desde el punto de vista de la credibilidad atribuida a los distintos medios, el mismo estudio vuelve a mostrar una gran ventaja para la televisión que es considerada como el medio más objetivo por 
el 36\% de la población, seguido de la radio con un 27\% de la preferencias y en tercer lugar por la prensa escrita con sólo un $12 \%$.

Por otra parte, resulta también claro que, siendo diversos en su oferta, la eficacia simbólica variará no sólo en función del tipo de medio sino también de los formatos, los contenidos y el contrato interpretativo implícito en cada caso. Tal como han puesto de manifiesto numerosos autores, el público es un agente activo en su relación con los medios y hace uso de sus contenidos, en parte, de acuerdo a sus propios intereses y necesidades: hay contenidos cuyo uso se relaciona más bien con el aprovechamiento del tiempo libre y la recreación, mientras que otros se vinculan con usos más práctico - instrumentales orientados a lograr un mayor dominio y un mejor desenvolvimiento en el medio social-. En este sentido, los contenidos informativos, y entre ellos muy especialmente los noticiosos, son los que mayor impacto tienen sobre la imagen que nos formamos del mundo que nos rodea, básicamente debido a su carácter representativo de "la realidad". Los datos arrojados por el estudio antes referido nuevamente son inequívocos en señalar la ventaja que la televisión tiene en este ámbito: $76 \%$ de los chilenos declaraba que la televisión era el medio que utilizaba de forma más frecuente para informarse de lo que ocurría en el mundo (contra sólo un $5 \%$ que señalaba hacerlo preferentemente a través de los diarios o la radio) y el $74 \%$ declaraba ver noticiarios de televisión abierta todos los días de la semana. De hecho, los noticiarios constituyen el programa televisivo que más se ve en familia al interior de los hogares, concentrando el 63\% de las preferencias, y la evaluación que existe de los mismos es bastante positiva: el 74\% de los entrevistados considera que informan adecuadamente de los problemas de otros países mientras que el $68 \%$ cree que informan de un modo adecuado los problemas del propio país y el $67 \%$ opina que sus contenidos incorporan los intereses de la gente. Los telediarios representan, por tanto, el contenido más valorado dentro del medio mejor evaluado.

¿Qué hace que sea precisamente este dominio discursivo y no otro el más valorado por el público?; ¿qué tipo de operaciones son las que permiten que los discursos de los telediarios lleguen a ser considerados como discursos de verdad, como si representaran una realidad exterior, anterior e independiente de ellos?; finalmente, ¿qué tipo de régimen de representación constituyen y sobre qué otros dominios discursivos se apoyan y cuáles son apoyados por ellos?

Hemos decidido llevar adelante esta investigación analizando un caso que nos parece a la vez ejemplar y paradigmático, tanto por la relevancia social que ha llegado a adquirir en los últimos 15 años, como por la cobertura y tratamiento que los medios y muy especialmente los noticiarios televisivos le dan: el tema de la delincuencia. Un estudio realizado el año 2005 por el CNTV respecto de la calidad de los noticiarios centrales de la televisión indicaba que éstos dedican un 12\% del total de sus contenidos a temáticas relacionadas con el ámbito policial, siendo el contenido al que más tiempo se le dedica después de los deportes. De hecho, el mismo estudio establece que, si 
se agrega al tiempo dedicado a temas policiales aquél que se dedica al sector justicia, la proporción total dedicada alcanza al 20\%, lo que nos permite afirmar que, con cierta distancia, estamos ante el tema relacionado con la vida cotidiana que mayor representación tiene en los noticiarios de la televisión.

El texto se divide en dos partes y contiene, en total, 5 capítulos. La primera de ellas busca situar y delimitar el problema de investigación y consta de dos capítulos: en el Capítulo 1 se aborda el problema de la relación entre los medios, la delincuencia y la seguridad ciudadana y se esbozan algunas hipótesis tentativas en relación con las mutuas dependencias que se establecen entre ellos, mientras que en el Capítulo 2 se describe la perspectiva teórica desde la que se aborda el problema de investigación y que se corresponde con el Construccionismo Social. La segunda parte da cuenta de los resultados de la investigación y abarca los 3 capítulos finales: en el Capítulo 4 se describe la metodología utilizada en la investigación y se entrega un reporte de los resultados del análisis cuantitativo al que fue sometida la muestra; en el Capítulo 5 se describen los resultados del análisis cualitativo en términos de la forma en que los telenoticiarios representan al sujeto delincuente al interior de sus relatos, identificándose una tipología al interior de dicho espacio representacional; finalmente, en el Capítulo 6 se entregan los resultados del análisis cualitativo respecto de las operaciones discursivas que en ellas se actualizan. 
PRIMERA PARTE

EL PROBLEMA DE INVESTIGACIÓN Y SU
ENTORNO TEÓRICO Y EPISTEMOLÓGICO 


\section{Capítulo 1}

\section{LA RELACION MEDIOS, DELINCUENCIA Y SEGURIDAD CIUDADANA: CONSIDERACIONES PRELIMINARES}

La mayoría de los textos e investigaciones desarrolladas en nuestro país en torno al tema de la delincuencia, lo abordan desde la perspectiva de la denominada $\ll$ Seguridad Ciudadana» o «Seguridad Pública». En este ámbito destacan los informes de carácter cuantitativo que periódicamente publican el Ministerio del Interior y la Fundación Paz Ciudadana, por nombrar sólo los principales referentes de cara a la opinión pública, cuyo propósito principal es abordar el daño directo producido por la delincuencia, así como proveer de información útil para la toma de decisiones y la elaboración de políticas públicas.

En comparación con ellos, los estudios que pretenden abordar el problema de la delincuencia de manera comprensiva y en relación a otros actores relevantes de la sociedad, son más bien escasos. Un trabajo digno de destacar en este ámbito es el de Marcela Ramos y Juan A. Guzmán (2000) quienes investigan acerca de la instalación en Chile del concepto de Seguridad Ciudadana y sobre cómo su introducción ha transformado varios ámbitos de la vida social de nuestro país: la forma en que se organizan las fuerzas de orden público, la aparición y auge de la seguridad privada y la criminalización de la pobreza, entre otras.

En el caso particular de aquellas investigaciones que buscan relacionar criminalidad y medios de comunicación, el foco de atención se ha centrado principalmente en conocer la incidencia que los medios tienen en la percepción de inseguridad y en el alza de las tasas de temor. Uno de esos trabajos es el de Cecilia Dastres (2003) quien intenta caracterizar el rol que cumplen los medios de comunicación en los fenómenos de violencia y criminalidad, cruzando tres niveles de análisis que corresponden a las dimensiones establecidas por los enfoques clásicos de las teorías comunicacionales. Estos ámbitos son:

1. Nivel del emisor: se refiere a la construcción de la noticia sobre criminalidad y violencia. Aquí se destacan las valoraciones de los periodistas y de las instituciones de comunicación sobre el fenómeno.

2. Nivel del mensaje: dice relación con los discursos construidos, es decir, con los contenidos específicos que se entregan. Dastres en su investigación señala que los medios son agentes importantes de configuración de imaginarios y símbolos sobre el problema en cuestión. 
3. Nivel de las percepciones: es la dimensión de la recepción de los mensajes construidos por los medios y el impacto que ésta tiene sobre la audiencia.

No obstante el análisis posee tres niveles, la investigación le otorga mayor centralidad al nivel de la emisión del mensaje periodístico, concluyendo que hay una inconsistencia entre la cobertura mediática de la delincuencia y la necesidad de información pertinente al objetivo de la elaboración de políticas de seguridad, la cual estaría explicada por los prejuicios de editores y periodistas.

Otro trabajo más reciente de la misma autora, en colaboración con Cristián Spencer, Eva Muzzopappa y Chiara Sáez (2005), insiste en la vinculación temorinfluencia de los medios. El estudio aborda de este modo el papel de la prensa y la televisión en el acrecentamiento de la sensación de inseguridad, suponiendo entre ambos una relación directa aunque sin abordar las categorías semánticas bajo las cuales se construye este supuesto.

En relación con lo anterior, algunos autores han supuesto que los medios de comunicación actúan como meros vehículos de información objetiva, dando cuenta de una realidad que es, efectivamente, insegura y atemorizante. Este es el caso de Enrique Gil Calvo (2003), quien postula que el discurso de los medios sobre el temor no dice relación tanto con la intencionalidad o ideología de éstos como con su capacidad estructural para crear alarma social. Sin embargo, autores como Chiricos, Padgett y Getz (2000) han problematizado esta idea sosteniendo que la evidencia empírica indica que el consumo de noticieros tanto nacionales como locales está significativamente relacionado con el temor a la delincuencia y que, entre ambos, la influencia de los noticieros locales es mayor. Es decir, la percepción de inseguridad no se relaciona tanto con los índices de victimización (esto es, la posibilidad real de transformarse en víctima de un delito en un momento determinado) como con la exposición a noticias que refieren a este tema.

Por otra parte, autores como D’Adamo y García (2003) postulan, basándose para ello en una serie de estudios desarrollados en Argentina en torno a lo que denominan Índice de Violencia Social Percibida (IVSP), que no existe una relación entre los índices de delictividad reales (medidos a través del número y tipo de denuncias efectivamente realizadas) y el aumento o disminución de la cobertura que los medios de prensa dan al tema de la delincuencia; los datos por ellos obtenidos indicarían más bien dicha cobertura tiene que ver con que el tipo de delitos cometidos se ajuste a la lógica de los leading cases (casos que inician o que se les considera paradigmáticos de una cierta tendencia delictiva) o bien, con que en torno a ellos pueda construirse una cierta narrativa de tipo emotivo-dramático que facilite la identificación de la opinión pública con la víctima. Es decir, contrario a lo que el sentido común indica (esto es, los noticieros reflejan lo que en verdad ocurre) la agenda temática de los medios en esta materia, mantiene una autonomía relativa respecto de las tendencias efectivamente presentes en la sociedad. 
Todo lo anterior supone que en una de las materias más sensibles para el público desde el punto de vista de su cotidianidad, los noticiarios televisivos poseen una influencia significativa sobre la forma en que las personas se representan la realidad social a pesar de que sus contenidos no aparezcan completamente determinados por la lógica de los hechos e, incluso, puedan resultar no totalmente compatibles con la propia experiencia. ¿Por qué, entonces, poseen ese nivel de influencia?

Nuestra hipótesis es que ello se explica porque la prensa y muy especialmente los telenoticiarios han logrado desarrollar un régimen de representación que los hace aparecer ante el público como si reflejasen la realidad de un modo completamente transparente $\mathrm{y}$, de hecho, más completo, panorámico y representativo que la propia experiencia personal (por lo que logran imponerse a ella). Dicho régimen representacional estaría articulado en torno a unas ciertas estrategias de veridicción (asociadas a un discurso de tipo factual) y a su ubicación nodal en una red de apoyos y solidaridades mutuas establecidas con otros dominios discursivos de orígenes y raigambres completamente diversas pero que se encuentran asociados, todos ellos, en el nivel más profundo, a lo que Foucault (1996) denomina "tecnologías del yo".

En esa dirección, la temática sobre delincuencia y seguridad en los medios se articularía con discursividades de larga historia en nuestro país, que dicen relación con las percepciones de las elites acerca de lo popular, entendido como un otro radical, potencialmente amenazante. La industria cultural y los medios no han sido ajenos a ellas. En la actualidad, una de las formas en que se manifiesta la presencia de lo popular en el discurso televisivo está asociada a la idea de la amenaza y el temor. Pero, ya no se trata de la figura del roto alzado organizado en sindicatos o militante de partidos que, en tanto actor colectivo planteaba en su accionar la posibilidad de remover las bases del poder de los sectores dominantes. La figura actual es una amenaza directa a los bienes y las personas, pero sin ninguna perspectiva más allá del beneficio individual de los agresores. Las pantallas televisivas están permanentemente mostrando la amenaza de la delincuencia sobre los barrios acomodados. Lo popular como amenaza también aparece ligado al narcotráfico y a la existencia de pandillas y bandas que asolan barrios y poblaciones.

Desde la reinstauración del sistema democrático liberal representativo en 1990, fue emergiendo en el discurso mediático el tema de la delincuencia y la seguridad, planteado como uno de los problemas más centrales de la vida nacional. En este plano, pareciera constatarse un éxito de estas estrategias. Tanto los estudios de opinión como el accionar de los partidos políticos han ratificado, de manera bastante tautológica, esta suerte de profecía autocumplida. Así, el fantasma que recorre Chile es el del sujeto delincuencial construido por las discursividades mediáticas, como principal amenaza a la convivencia y el orden, que asume los rostros del asaltante de casas, del ladrón callejero o en una versión más juvenil, el del vándalo infiltrado en manifestaciones sociales, culturales o políticas de la ciudadanía sana. Esa representación nos permitiría 
constituirnos a nosotros mismos y a la gente como nosotros, como si fuésemos sujetos completamente diferentes de ellos y, en esta medida, incapaces de ejecutar las acciones que ellos ejecutan, participar en los hechos en que ellos participan y, en definitiva, compartir el destino que ellos poseen.

Ahora bien, las condiciones a partir de las cuales los medios de comunicación y la prensa en particular adquieren esta capacidad de influencia y de organización de los social no corresponden ni mucho menos a los últimos años, en nuestro país vienen estructurándose, por lo menos, desde la segunda mitad del siglo pasado.

A continuación realizaremos una breve genealogía de la constitución de dichas condiciones para, posteriormente, deconstruir algunos de los supuestos básicos desde los que se analizado tradicionalmente el rol de los medios en esta materia. 


\section{Capítulo 2 \\ PRENSA, DISCURSO PERIODÍSTICO Y TELENOTICIARIO}

En su desarrollo, la prensa liberal moderna logró una articulación clave entre el autodesignado rol de vocero y orientador de la opinión pública, por un lado, y el logro de sus intereses económicos, ligados a los procesos de masificación y ampliación del mercado, por el otro. Ello es entendible alrededor de la noción misma de noticia, como materia prima básica del periodismo moderno y de la idea de prensa como mediador entre los individuos y la sociedad:

El nuevo concepto de noticia que hizo su aparición en la segunda mitad del siglo pasado ejerció una fuerte influencia en el aspecto formal de la crónica [...] Esta nueva modalidad demostró que las noticias podían hablar por sí mismas (Charnley, 1971, p. 229).

El imperio de lo noticioso determinó la aparición de géneros, estilos y técnicas periodísticas específicas. La noticia debía ser escrita en forma breve, precisa y escueta, sin adjetivos ni opiniones. La propia técnica aseguraba la neutralidad del periodista, profesional específico surgido con la aparición de la empresa periodística, cuya posición y función se legitimaba desde una cuasi ontología profesional, que lo ubicaba como testigo de la historia, objetivo, pero a la vez comprometido con la verdad y al servicio del público. Esta paradójica dualidad sólo era sostenible en la medida en que se asumiera axiomáticamente el hecho de que las noticias existían en tanto que tales y que la prensa lo que hacía era simplemente registrarlas.

El modelo informativo habría de generar un modelo complementario. Aparece así la idea del periodismo interpretativo (sobre la base del género reportaje), impuesto en la década de los ' 20 por la revista Time. A pesar de que la técnica exige "en primer lugar, establecer claramente cuál es el punto de vista de nuestra crónica" y que "es la tarea de situar en un contexto, explicar las motivaciones más profundas, analizar el sentido de la corriente diaria de noticias, separando lo trascendental de lo irrelevante", sin embargo, "esta interpretación debe tratar de prescindir de opiniones personales" (Santibáñez, 1974). En aras de la neutralidad se logra un verdadero milagro: se sitúan hechos en un contexto, se identifican y analizan sentidos, se separa lo importante de lo secundario, pero todo ello sin emitir opiniones. Se supone entonces que la prensa sólo opina a través de la editorial y la eficiente aplicación de las técnicas permitirían la distancia que se postula frente a los hechos, ya que en definitiva "la objetividad no es otra cosa que contar los hechos tales como son" (Filippi, 2000).

En ese marco, la prensa moderna se sostenía sobre dos pilares: por un lado, la existencia de la noticia y, por otro, la capacidad de difundirlas masivamente. 
La capacidad de encontrar las noticias, vale decir de seleccionar aquellos hechos necesarios como insumos para la formación de la opinión y de expresarlas de tal manera que fueran fácil y rápidamente decodificadas por un público anónimo y heterogéneo, fue lo que delimitó el campo propio y específico del periodista (vale aquí incluir la mitología del olfato y la intuición periodísticas, para algunos atributos innatos; para otros, factibles de formar y adiestrar):

No puede existir [...] ni como supuesto teórico [...] un periodismo sin lectores... La recepción es, pues, un factor imprescindible para que exista periodismo. El factor estético crea Literatura. El factor comunicativo crea periodismo. Un texto sin lectores puede ser Literatura, pero nunca periodismo (Casasus y Núñez, 1991, p. 66).

Una particular forma expresiva y un específico contenido (la noticia) permitieron, entonces, delimitar el campo del periodista con referencia al texto literario. Ello está en la base y el origen del periodismo informativo moderno ${ }^{1}$. Más importante aún es que lo anterior permitió el desarrollo de la visión del periodismo como mediación social. Así, el periodista como mediador es el que tenía por función entregar la visión de totalidad del acontecer (los hechos de Chile y el mundo) y con ello activar las relaciones y prácticas sociales, constituir opinión y ser su portavoz y, en un sentido tal vez más trascendente, configurar con ello un sentido común cristalizado, en tanto materialización masiva de un saber elaborado y sistemático (Gomis, 1991; Fontcuberta, 1993):

Los medios ejercen de esta manera una mediación general encaminada a lograr que todos se enteren de lo que hacen todos, lo entiendan y lo comenten y que en lo posible todo el mundo intervenga e influya en todo. Así contribuyen los medios a que la sociedad gobierne y controle su propia conducta (...) La mediación generalizada de los medios estimula la acción social (Gomis, 1991, p. 198).

Por ello, el autor citado recalca que esta interpretación de la realidad sería activadora de la sociedad, que haría que la gente hable, piense y actúe, que quiera intervenir en esa misma realidad que se le da a conocer, por lo cual se haría insustituible la relación entre la democratización y masificación de la noticia con la democratización política. La prensa como mediación social aparece entonces como inseparable de la existencia del ciudadano, de lo público y de un orden social liberal-democrático.

1 Para el caso de la prensa chilena, ver Ossandón, C. y Santa Cruz, E. (2001). Entre las alas y el plomo. La gestación de la prensa moderna en Chile. Santiago: Ediciones Arcis-LOM, en especial respecto al lugar y función de la crónica como género de transición entre lo literario y lo informativo y como espacio para un posicionamiento de nuevo tipo del escritor frente a un emergente público masivo, a fines del siglo XIX. 
Por otro lado, el fundamento de esa actividad mediadora era la existencia de la noticia. No es el propósito del presente texto dar cuenta del frondoso caudal de enfoques y posturas sobre el tema, sino poner de relieve el estatuto de aquello que para la prensa moderna es su materia prima y que, según Gomis (1991) equivale a la realidad social presentada como acción. En ese sentido, y trascendiendo las formulaciones descriptivas, cuando no francamente anecdóticas, tal vez la más precisa sistematización de lo que era la noticia en el periodismo moderno es aquella que la conceptualiza como una improbabilidad socialmente relevante (Torres, 1975) ${ }^{2}$. En esa dirección, se afirma que para el periodista la realidad es un conjunto de alternativas probables o improbables. Por lo tanto, mientras mayor es la improbabilidad de que un hecho acontezca, mayor será su carga de novedad y su medida de información. Dicho criterio viene a ser fundamental para develar los criterios de selección de los hechos dignos de constituirse en noticias (entre otras cosas, hay aquí un criterio básico para entender lo que el sentido común denomina como sensacionalismo, especialmente en una realidad de mercado informativo). Sin embargo, lo anterior no basta, ya que dicha improbabilidad debía ser socialmente relevante. Con ello, la idea de noticia aparecía inseparable de la noción de interpretación de la realidad social y, en ese sentido, constituía una concepción del periodismo moderno que contenía su propia crítica: "el Periodista -en rigor- no comunica la realidad de un acontecimiento, de una improbabilidad social; sino que da a conocer una forma de interpretación de esa improbabilidad social" (Torres, 1975).

Dicha visión le otorgaba un fundamento conceptual sistemático a la actividad periodística, y también, sobre esa base, desmistificaba la concepción liberal clásica de que los hechos hablan por sí mismos. En ese sentido, apuntaba en la misma dirección de otros enfoques de la época que intentaron desmontar el mecanismo ideológico que subyacía al modelo informativo liberal moderno, en cuanto representación falseada de lo real ${ }^{3}$, enfrentándose a la pretensión de la prensa liberal moderna de erigirse como portavoz de la opinión pública. En otras palabras, el debate acerca de la intención manipuladora de la prensa tenía sentido, en tanto ella intentara establecer un lazo efectivo con la sociedad civil (al decir de Gramsci) tras la construcción de hegemonía, lo cual suponía que la prensa tenía algo que decir sobre la realidad. En definitiva, la discusión se sostenía en la pugna legitimada entre distintas versiones o

2 A partir de la aplicación del modelo informático, en este texto se ponen de manifiesto de manera sistemática las estructuras de base de la información periodística.

3 Nos referimos obviamente a los trabajos clásicos: Mattelart, A. y Mattelart, M. (1974). La Comunicación masiva en procesos de liberación. México D.F.: Siglo XXI y Mattelart, A. y Mattelart, M. (1970). La ideología de la prensa liberal en Chile. Santiago: Cuadernos de la Realidad Nacional $\mathrm{N}^{\circ} 3$ - CEREN, por un lado, y en otro enfoque, Verón, E. (1971). Lenguaje y Comunicación Social. Buenos Aires: Ediciones Nueva Visión. 
interpretaciones de los hechos socialmente relevantes, lo cual suponía, a su vez, la existencia plena del espacio de lo público.

Inhabilitada la pretensión acerca de la existencia objetiva de las noticias y de la prensa como mero reflejo o registro de esa realidad informativa, constituida previa y autónomamente, se fueron instalando en los últimos años visiones sobre el periodismo que lo conciben más bien como un actor social y político generador de un particular tipo de discurso social. Un marco más global de aquello lo constituyó la teoría de los efectos cognitivos de la comunicación y la llamada hipótesis de la agenda-setting, en su aplicación a la prensa (Wolf, 1987). En definitiva, ellas apuntan a instalar la actividad periodística como una forma de construcción social de la realidad, siguiendo el enfoque de Berger y Luckman ${ }^{4}$.

Rodrigo Alsina, especialmente, pondrá el énfasis en que la construcción de la realidad efectuada por los periodistas implica la competencia socialmente aceptada para recoger los hechos y atribuirles un sentido y, además o junto y a través de ello, la transmisión de un cierto tipo de saber y su efectividad no estaría en la persuasión (hacer-creer) o en la manipulación (hacer-hacer), sino fundamentalmente en el hacer saber, en su propio hacer comunicativo. En ese sentido, dicho autor afirma que: "el periodista se convierte en una de las principales figuras sociales encargadas de aquello que podríamos llamar 'la certificación institucional de la verdad" (Rodrigo Alsina, 1996, p. 178).

De alguna forma, es posible establecer una cierta analogía entrela labor periodística y la labor científica. Al decir del autor que reseñamos, ambos pretenden dar cuenta de la realidad, parten de una base empírica y manifiestan profesar una actitud de objetividad. Una de las diferencias más importantes entre una y otra práctica es que el periodista difícilmente puede plantearse los problemas epistemológicos de su propio trabajo, ya que es más bien: "un hombre de acción que debe producir un discurso con las limitaciones del sistema productivo en que está inserto" (Rodrigo Alsina, 1996, p. 178).

El discurso periodístico es un discurso social y, en tanto tal, está inserto en un sistema productivo. En esa dirección, la construcción noticiosa supone tres fases: la producción, la circulación y el consumo. Al decir de Rodrigo Alsina (1996), la producción de la noticia es una: "actividad compleja que se realiza de forma industrial, en el seno de una institución reconocida socialmente” (p. 178).

A esta fase la denomina la fase oculta de la producción, inaccesible a la mirada del

4 Consultar Van Dijk, T. A. (1996). La Noticia como discurso. Barcelona: Paidós y Rodrigo Alsina, M. (1996). La construcción de la noticia. Barcelona: Paidós. Sin embargo, en Chile todavía circulan enfoques que siguen caracterizando al periodismo como una actividad que "muestra la realidad": consultar Puente, S. (1997). El drama hecho noticia. Santiago: Ediciones Universidad Católica de Chile. 
público, el que solamente conoce el productoterminado. De este modo, la noticia viene a ser una representación social de la realidad cotidiana producida institucionalmente. Sus productores, los periodistas, establecen una relación con sus destinatarios, a partir de un contrato fiduciario social e históricamente definido. Dicho en otros términos, la sociedad legitima su actividad orientada a construir discursivamente la realidad de su entorno, darle forma de narración, convirtiéndola en una realidad pública y socialmente relevante. A los periodistas se les atribuye la competencia de escoger (recoger) los acontecimientos y atribuirles un sentido.

Sin embargo, en la caracterización del periodismo como un discurso social más, permanece presente la posibilidad de representación de una realidad referencial y con ello de la pretensión por la verdad, como aprehensión de una exterioridad social objetiva. En justicia, es el citado Rodrigo Alsina (1996) quien abre la perspectiva de una mirada distinta al poner de relieve el problema de la verosimilitud del discurso periodístico, es decir, que el hecho de que éste deba ser creído por el enunciatario es imprescindible para su efectividad en tanto que tal. De todos modos, lo que no discute es la existencia del otro lado del vínculo al asegurar que: "el periodista es el enlace del conocimiento de políticos, filósofos y científicos con el ciudadano" (Rodrigo Alsina, 1996, p. 180).

Agrega el autor que en el proceso de construcción de la noticia, por parte del periodista, intervienen lo que denomina tres mundos. El primero es el mundo real, que es el de los acontecimientos y los hechos. Luego de producida la selección de aquellos, el periodista los encuadra en mundos de referencia, que son modelos y construcciones culturales que permiten su comprensión y puesta en sentido. La elección de esos esquemas referenciales supone procesos de intertextualidad y de conexión con el sentido común imperante. Se toman datos de otros hechos que permitan corroborar la correcta elección del modelo.

En la medida en que estos mundos referenciales están situados en las coordenadas del sentido común masivo suponen un alto grado de historicidad social y cultural, lo que significa que las posibilidades de elección de ellos son limitadas por esas condicionantes. La elección del mundo referencial es fundamental, pues a partir de él se va a buscar la verificación del mismo en nuevos acontecimientos. En todo caso, lo fundamental es que el mundo de referencia escogido sea el de mayor verosimilitud y credibilidad.

A partir de lo anterior, el periodista construye un mundo posible, que articula los mundos anteriormente citados y que tiene como matriz al mundo de referencia. El mundo posible es confrontado con los nuevos datos que se vayan aportando sobre el acontecimiento, lo que vendrá a confirmar, invalidar o corregir la elección del mundo referencial. De este modo, concluye Rodrigo Alsina (1996), si en el mundo real se produce la verificación y en el mundo de referencia se determina la verosimilitud, en 
el mundo posible se desarrolla la veridicción. Dicho en otros términos, el periodista debe hacer parecer verdad el mundo posible que construye.

Por ello es que se puede afirmar que lo que hoy predomina ( $y$ en ello la prensa televisiva es su expresión máxima, pero no la única) es un periodismo difusor de verosímiles, es decir, que no tiene una verdad o causa que transmitir, sino que difunde lo que la gente está dispuesta a creer:

en algún momento durante los años '90, el centro de gravedad de los espacios informativos se desplazó desde la oferta imprevisible de la actualidad y la permanencia de las políticas editoriales hacia los cambiantes intereses del público [...] Mientras estuvo vigente el formato tradicional, ninguna información reciente que el equipo productor juzgara relevante podía ser escamoteada al público, aunque para lograr ese objetivo se la redujera a sus elementos más triviales [...] Hoy, de acuerdo con la evidencia, la TV chilena no teme escoger la desinformación que le solicitan sus consumidores, con tal de mantener el rating (Garaycoechea, 1997).

Aldecir de Bourdieu (1997), el campoperiodístico posee hoy una lógica específica, propiamente cultural, que se autodefine como orientada hacia la producción informativa. Ello determina que la competencia por los clientes (consumidores y anunciadores) tiende a adoptar la forma de una competencia por la prioridad, es decir, aquello conocido antiguamente como golpe periodístico es reemplazado por la primicia (no importa lo que se diga, sino que se diga primero). Su efecto es que muchas de esas primicias están condenadas a permanecer ignoradas por los receptores y a ser advertidas sólo por los competidores (los periodistas son los únicos que leen el conjunto de los periódicos). De este modo, señala el autor, la competencia por la prioridad atrae y favorece a los agentes dotados de disposiciones profesionales que tienden a poner toda la práctica periodística bajo la advocación de la velocidad y renovación permanente; de igual forma, es la competencia intra-campo la que provoca el ejercicio de la vigilancia permanente de los competidores: así, hay temas de los que no se puede no hablar e invitados que hay que tener, etc. A contrapelo del dogma liberal, en el periodismo actual, la competencia, lejos de ser automáticamente generadora de originalidad y diversidad, tiende a favorecer la uniformidad de la oferta:

Para ser el primero en ver algo, y en mostrarlo, se está dispuesto a lo que sea, por así decirlo, y como todo el mundo se copia mutuamente para adelantarse a los demás [...] todo el mundo acaba haciendo lo mismo, y la búsqueda de la exclusividad, que, en otros campos, produce originalidad y singularidad, desemboca en éste en la uniformización y banalización (Bourdieu, 1997, p. 27). 
Otro importante efecto de campo que señala Bourdieu (1997) es la llamada circulación circular de la información. A partir del hecho anterior, de que para saber lo que uno va a decir, es indispensable saber lo que han dicho los demás, se establecen entre los medios sutiles diferencias del todo imperceptibles para el espectador o lector medio (que no lee todos los periódicos y revistas, ni ve todos los telenoticiarios o programas informativos). Así, los periodistas que comparten muchas características comunes por su condición y formación, se leen mutuamente, se ven y encuentran constantemente, generando un efecto de enclaustramiento que para el receptor opera de hecho como mecanismo de censura. Por ello, ante la pregunta de cómo se informan aquellos encargados de informarnos, resulta que en líneas generales son informados por otros informadores. En definitiva, se puede concluir en que la parte más determinante de la información, la constituye información sobre información. El llamado espacio público u opinión pública, en la actualidad no pasa de ser la difusión circular en gran escala de informaciones.

Ello implica, por otro lado, que ya no son los hechos los que preceden a la noticia, con la posibilidad de construcción y producción de aquella y su potencialidad de manipulación y sus efectos de alienación. Más allá y al revés de eso, lo que estaría ocurriendo es que es la información la que genera el acontecimiento y los hechos, lo cual tendría consecuencias incalculables, pues la labor y la presencia de lo negativo y lo alternativo desaparece en el horizonte de los medios (Baudrillard, 1993). Así, por ejemplo, la estética de la fragmentación, característica del telenoticiario (Vilches, 1989), es lo que permite la difusión del acontecimiento hasta el infinito alcanzando una velocidad de no-retorno, que lo aleja definitivamente de la historia. Si hay un rasgo distintivo del acontecimiento, que lo hace ser tal y tener valor de historia, es que sea irreversible. En la actualidad asistimos a lo contrario, en el sentido de que todo es reciclado en la perspectiva de una sensatez común, todo se re-escribe, se restaura, se adecenta.

Al decir del citado Vilches (1989), el noticiero televisivo se construye con segmentos y textos citados de agencias de noticias, de corresponsalías, de centros regionales, de TV extranjeras, etc., los que a su vez también provienen de otras fuentes y materiales, en el sentido que señala Bourdieu (1997) de que los informadores se nutren de otros informadores. De allí surge la ya señalada estética de la fragmentación que se actualiza diariamente, como en una continuidad sin fin (nadie sabe dónde comienza y dónde termina). La TV se apropia de palabras e imágenes ajenas, las aplica a alguna cosa y termina diciendo algo diferente. Por lo tanto, lo importante no es algún sentido de totalidad, sino, por el contrario, el sentido de continuidad que recibe el espectador.

Por otro lado, aunque resulta obvio para una mirada entendida, no está demás recalcar que la TV no es la ventana al mundo, sino un texto audiovisual sobre la realidad visto por la estrecha ventana de la pantalla. Agrega Vilches (1989) que este 
texto informativo tiende cada vez más a la abstracción y el juego de las formas: pausa y movimiento del VTR; congelamiento de la imagen; ráfagas sintéticas y anagramas digitales; chromakey y presentadores que recitan o leen de otra imagen mientras miran a los ojos; escenarios virtuales, etc.

La información televisiva construye su propia realidad: la realidad televisiva que, insiste el autor, no es sino un texto, entre otras razones por la selección e interpretación que implican las decisiones de encuadre, planos, movimientos y angulaciones de cámara, uso del sonido, etc. Y por la puesta en escena del acontecimiento, no solamente en el estudio, sino que también en el directo, ya que la TV influye en el propio desarrollo del acontecimiento, en la medida en que su sola presencia construye un estudio en cualquier sitio. La puesta en escena del discurso informativo comprende el programa mismo, el lugar que ocupa en la programación, la construcción de los valores informativos y la instalación de los sujetos de la información.

La puesta en discurso del telenoticiario supone la utilización de un conjunto de técnicas. Entre ellas, Vilches (1989) destaca las siguientes: la selección, que implica efectuar una incisión en el conjunto para aislar un fragmento que se convertirá en un texto informativo. Aquí se produce necesariamente una manipulación, en el sentido de que todo acto de lectura, traducción e interpretación conlleva la alteración, porque escribir un texto es siempre rescribir, como editar una postproducción de video es, de algún modo, volver a grabar. En segundo lugar, el subrayado o la focalización, que significa que los núcleos de información original se pueden reordenar modificando sus prioridades y sus funciones originales; Vilches pone como ejemplo convertir un despacho sobre datos económicos en una breve historia de éxitos o fracasos de la política económica de un gobierno. O bien, escoger noticias diferentes poniéndolas en una secuencia tal que genere o sugiera una lectura de causa/efecto indirecta, como ocurre, por ejemplo, con actos de violencia o crimen, seguidos de manifestaciones sociales o grupales.

Por último, el autor que reseñamos hace mención al injerto, que es cuando la cita de una información aparece como un cuerpo extraño de un texto. Todo injerto es una especie de cirugía, pero es propio de la labor de reescritura del telediario, convertir núcleos informativos o narrativos separados y discontinuos en un todo coherente y comprensible. Un informativo es siempre un collage, de ahí la importancia del montaje o edición.

Por otra parte, es necesario insistir en que en la TV el texto verbal no es aislable ni tiene sentido por sí mismo. El sentido emerge del discurso audiovisual, es decir de la articulación del texto verbal con la estructura narrativa, la puesta en escena, la complejidad de sucesiones temporales, de secuencias espaciales, etc. El espectador no ve el proceso de construcción discursiva, pero recibe el efecto de sentido que ella porta. 
Finalmente, Vilches (1989) da cuenta de algunas de las operaciones discursivas que están presentes en el telenoticiario. En primer lugar, cabe mencionar el uso del silencio o el grado cero de la información, que es abstención de la palabra, aunque no del discurso, porque el silencio es productor de sentido. El caso extremo del silencio intencional es la censura, pero también existe un silencio más bien funcional que pretende una reducción de la entropía y la redundancia. En seguida, es posible mencionar la cita que se trata de informar con un mínimo de elementos; la información no se anula, pero tampoco se hace totalmente explícita y por ello está relacionada con un fuerte criterio de selectividad y reescritura al mismo tiempo. Es un tipo de información de carácter indicial, en el sentido de Peirce.

Un tercer tipo de operación es la reconstrucción, que es la más habitual y que está destinada a otorgarle legibilidad al texto, es decir, que sea leído, visto y escuchado rápidamente y comprendido sin dificultad. Su forma más simple es el resumen, de todas formas más explícito que la cita, ya que tiende a estar regido por las reglas clásicas del periodismo informativo, que pone en el centro qué sucedió. Otro tipo es la focalización que tiene al centro la operación retórica del énfasis. Un ejemplo claro de ello son los llamados titulares en el telenoticiario. Aquí cabe el uso de diversas figuras retóricas propias del lenguaje verbal (apóstrofe, interrogación, hipérbole, etc.) como las propias de la imagen (ritmo, planos, sonido, etc.).

Otro mecanismo es el comentario que implica integrar elementos no previstos como informaciones que se añaden o que contextualizar. Lo importante es que no se trata solamente de palabras, sino que incluso puede tratarse de elementos kinésicos, como un movimiento de cejas, una determinada expresión facial, etc. Más aún, en todo telenoticiario es posible advertir distintos tipos de comentarios: palabra sobre palabra, palabra sobre imagen, imagen sobre palabra y también y de manera relevante, imagen que comenta a otra imagen.

No menos importante es el ocultamiento focalizando ciertos contenidos y ocultando otros, por ejemplo a través de la combinación confusa entre lo importante y lo secundario. El ocultamiento también se da en las relaciones entre lo verbal y lo icónico. Vilches (1989) menciona el ejemplo de un político poco conocido dando una declaración en un pasillo por donde están circulando las figuras políticas más importantes, con lo que lo más probable es que el texto verbal del político pase desapercibido. También hace referencia a que una forma eficaz y sutil de ocultamiento está en lo que parece su inverso, como es la saturación de información, como ocurre con la entrega de imágenes, datos y palabras al mismo tiempo y con gran ritmo narrativo.

Finalmente, el autor hace referencia a la conmutación, que es una perspectiva invertida que trata de armonizar con un texto original un enfoque discursivo que es contrario al sentido original. Generalmente combina algunos o todas las operaciones anteriores. A nivel de la imagen, por ejemplo, significa alterar la continuidad de una 
secuencia o de varias imágenes dentro de ella, como separar dos imágenes que iban juntas para intercalar una tercera que cambia el sentido de la lectura; extraer una imagen o una frase de una secuencia para introducirla en otro texto o bien, invertir el orden de la secuencia cambiando el efecto por la causa o viceversa.

En este progresivo abandono de lo real como referente es necesario incluir la factibilidad de la construcción de una hiperrealidad, producto del maridaje entre el lenguaje audiovisual, la informática y la interacción medial. Eliminando los marcadores clásicos entre la verdad y la ficción, presentes en toda sociedad y toda cultura hasta ahora, la realidad virtual es el espacio propio del simulacro, que no corresponde a un territorio, a una referencia, a una sustancia, sino que es la generación por un modelo de algo real, sin origen ni realidad. La verdad, la referencia, la causa objetiva son indiscernibles ${ }^{5}$. Por eso, además, es que el periodismo actual en sus tendencias predominantes está muy lejos de ser una causa o un apostolado tras la búsqueda de la verdad. Se trata más bien de una operación informativa que le señala a sus consumidores lo que quieren oír, lo cual equivale a decir, en su reverso, que les da aquello que están dispuestos a creer.

Al decir de Bourdieu, la lógica de mercado introduce un nuevo principio de legitimidad que consagra el número y la visibilidad mediática, la simulación democrática. Al igual que en la política, el sondeo y la medición cuantitativa (de rating o lectores) instaura con los receptores individuales una relación directa, sin mediación, desalojando a todos los agentes colectivos (antes socialmente designados para elaborar y proponer opiniones) y desposeyendo a todos los mandatarios y portavoces de ser expresión legítima de la opinión pública.

El periodista que ya no puede ser un mediador, se convierte, más allá de su voluntad, en un "custodio autoconstituido y autoreferente de los valores colectivos" (Bourdieu, 1997), permanentemente sometido a la prueba de los veredictos del mercado, lo cual lo lleva a adoptar el "criterio de los índices de audiencia o de venta" en su producción (simplificar, abreviar, etc.) o en la valoración de los productos y/o de los productores (resulta en la tele, se vende bien, etc.).

No obstante que de lo hasta aquí dicho resulta claro que el discurso de la prensa más que reflejar, construye el mundo en que vivimos, la adecuación entre los contenidos por ellos expuestos y la realidad social sigue siendo uno de los criterios fundamentales para evaluar la calidad de sus contenidos. De algún modo se ha pensado que el material que ellos exhiben será mejor (incluso éticamente) si "refleja" lo que "realmente" ocurre en el mundo, si se ajusta al mundo, al punto que gran parte

5 Un análisis específico de ello en Baudrillard, J. (1991). La Guerra del Golfo no ha tenido lugar. Barcelona: Anagrama. Si bien el fenómeno es de origen televisivo, por los efectos de campo antes mencionados, arrastra normalmente al conjunto de la prensa, cuestión recurrente en nuestra realidad. 
del impulso crítico en esta materia ha estado presidido por la idea que los medios, de una u otra forma, traicionan la realidad y distorsionan los hechos. Piénsese, por ejemplo, en la afirmación - bastante frecuente- que los medios producen estereotipos respecto de tal o cual grupo social (los pobres, los jóvenes, las mujeres), es decir, que exhiben una imagen sesgada de ellos dentro de la cual se sobre-representan los aspectos negativos y se minimizan u ocultan aspectos que pudiesen resultar positivos. En estos casos la crítica a los medios tiene que ver, precisamente, con la idea que ellos desfiguran intencionadamente lo que dichos grupos son en sí mismos.

No es el propósito de este trabajo cuestionar la utilidad de estas lecturas (que podríamos agrupar bajo la denominación genérica de "crítica ideológica") en términos del carácter deconstructivo que muchas veces poseen respecto de una serie de naturalizaciones que subyacen en los discursos propuestos por los medios de comunicación; desde muchas perspectivas compartimos este esfuerzo. De lo que se trata, más bien, es de problematizar el supuesto mismo según el cual la realidad social tendría unas ciertas características que le son inherentes, esto es, que poseería una cierta modalidad de existencia completamente independiente de nuestras formas de acceso a ella y de nuestras descripciones respecto de ella y que constituiría el fundamento último para evaluar la corrección o la exactitud de una representación. La idea que los medios pueden (o incluso deben) ser fieles a la realidad, que sus contenidos deben ser contrastados con los hechos sociales y que éstos constituyen el tribunal último para determinar su grado de verdad está a la base de la idea que la principal función que ellos cumplen es de tipo representacional. Incluso perspectivas de corte marcadamente constructivista como la de Miquel Rodrigo Alsina (revisada anteriormente) terminan por garantizar a la realidad social un estatus ontológico propio. En su caso, esto ocurre a través de la idea de un "mundo real" que existe más allá de nuestras prácticas en relación con él y que sirve como base material para la generación de "mundos de referencia” en función de los cuales la prensa produciría "mundos posibles".

En la presente investigación adoptaremos una perspectiva decididamente norepresentacional y afundacional y asumiremos de modo radical la premisa según la cual los medios de comunicación no representan la realidad sino que participan del proceso a través del cual ella se construye y llega a constituirse como tal realidad.

Para ello recurriremos al punto de vista desarrollado por el Construccionismo Social e intentaremos explorar qué imagen de los medios y del discurso periodístico emerge cuando se abandonan los supuestos realistas y representacionistas y qué posibilidades se abren (o se clausuran) respecto de los modos de interrogación y de la constitución de objetos de investigación específicos. También nos haremos cargo de algunas de las críticas realizadas a dicho enfoque perfilando los límites de su propuesta analítica. 


\section{Capítulo 3 \\ EL CONSTRUCCIONISMO SOCIAL: VERDAD, REALIDAD $Y$ MEDIOS DE COMUNICACIÓN}

No obstante ser una perspectiva desarrollada desde hace ya varias décadas y poseer importantes implicancias para el desarrollo de las Ciencias Sociales, el Construccionismo Social o Socioconstruccionismo ha recibido relativamente poca atención en el ámbito de los estudios en comunicación. Por este motivo, lo primero que haremos será una breve presentación de algunos de sus principales postulados para, a continuación, ver la forma en que pueden aplicarse a la investigación en el campo de los medios.

Históricamente, el socioconstruccionismo surge en el contexto de la crisis que desde fines de la década de los ' 60 y hasta bien entrada la década de los ' 80 remeció a toda la teoría social. Dicha crisis tiene su origen en el profundo cuestionamiento realizado desde múltiples puntos de vista a varios de los más importantes supuestos epistemológicos (e incluso ontológicos) del pensamiento moderno, especialmente a aquellos relacionados con el dualismo sujeto-objeto, con la idea de verdad como correspondencia, con la noción del desarrollo científico como saber acumulativo y con la idea misma de progreso.

Desde un punto de vista más específico, el socioconstruccionismo se vincula con el denominado "giro lingǘstico" (Rorty, 1990) que tanto en Filosofía como en Ciencias Sociales se concentrará en el análisis de las prácticas lingüísticas ya no como el medio transparente para acceder a eventos ocurridos en otro lugar (típicamente en la mente) sino para observar cómo la propia realidad es construida en y a través del lenguaje y las acciones que con él se relacionan. Lo que será puesto en entredicho a través de estos desarrollos es la visión (moderna) de la mente y el lenguaje como "espejos de la naturaleza" (Rorty, 2001); de la realidad social (pero también física) como algo exterior, anterior e independiente de nuestros modos de acceso a ella y del método científico como el camino privilegiado para conocer (objetivamente) sus características inherentes, derrumbando de un modo más o menos definitivo la idea misma de objetividad o al menos la de la posibilidad de un conocimiento objetivo ${ }^{6}$.

Especialmente importantes en este punto van a ser los aportes realizados desde campos tan diversos como la lingüística y la semiología (De Saussure, Peirce, Barthes), la antropología (Bateson, Geertz), el análisis literario (Bakhtin), la sociología de la ciencia (Berger y Luckman), la cibernética (Wiener), la biología

6 Por supuesto algunas modalidades débiles de realismo se mantienen como, por ejemplo, la sostenida por Searle (1997) en algunos de sus últimos trabajos. 
del conocimiento (von Glasersfeld, Maturana) o la psicología evolutiva de corte culturalista (Vygotsky), entre otros, los que posibilitarán que, paulatinamente, se vaya constituyendo el conjunto, más o menos heterogéneo, que agrupa a los distintos tipos de constructivismo y al construccionismo social.

\section{El núcleo teórico del programa Socioconstruccionista}

Aunque no se trata de un paradigma unificado sino más bien de una serie de propuestas que poseen un cierto grado de heterogeneidad, Kenneth Gergen (1996) enuncia los que, a su juicio, serían los cinco supuestos básicos del Construccionismo Social:

1. Los términos con que damos cuenta del mundo y de nosotros mismos no están dictados por los objetos estipulados de este tipo de descripciones. No hay nada a nivel de lo real que exija como necesaria una determinada descripción, cualquiera ésta sea, de modo que el vínculo entre lenguaje y realidad es convencional y no natural, no existiendo -en principio- límites en cuanto a nuestras posibilidades de caracterización de los estados de las cosas.

2. Los términos y las formas por las que conseguimos la comprensión del mundo y de nosotros mismos son artefactos sociales, productos de intercambios situados histórica y culturalmente $y$ que se dan entre personas. Así como las descripciones y explicaciones no provienen inexorablemente del mundo tal y como éste es, tampoco son el producto de unas propensiones genéticas o estructurales internas del individuo; más bien son el resultado de la interacción humana orientada hacia la acción y adquieren significado sólo en el marco de las relaciones actualmente vigentes. Esto significa que alcanzar la inteligibilidad implica participar en una pauta reiterativa de relación (que, si es lo suficientemente amplia, puede llegar a constituir una tradición). El carácter aparentemente transparente y aproblemático de las descripciones se deriva de que se encuentran culturalmente sedimentadas y articuladas con las prácticas sociales en curso, todo lo cual establece limitaciones contingentes a las descripciones posibles en cada contexto.

3. El grado en que un dar cuenta del mundo o del yo se sostiene a través del tiempo no depende de la validez objetiva de la exposición sino de las vicisitudes del proceso social. La metodología no proporciona una garantía trascendente respecto del nivel de validez de un enunciado, ni siquiera de un enunciado científico, puesto que pueden producirse variaciones en las descripciones sin que se verifiquen variaciones en los fenómenos descritos así como variaciones en 
los fenómenos sin que se observen variaciones en los enunciados. Como ha puesto de manifiesto Kuhn (1971), las formulaciones científicas se encuentran ampliamente sobredeterminadas por procesos sociales, lo que no implica que al interior de cada comunidad no puedan construirse regímenes de verdad $\mathrm{u}$ ontologías locales que operen regulando las formas de producción del conocimiento válido.

4. La significación del lenguaje en los asuntos humanos se deriva del modo como funciona dentro de pautas de relación. El significado es un emergente del proceso social y deriva de los intercambios que a nivel microsocial mantienen las personas como parte de las pautas culturales que estructuran formas de vida determinadas: la semántica pasa a ser vista como una derivación de la pragmática social.

5. Estimar las formas existentes de discurso consiste en evaluar las pautas de vida cultural; tal evaluación se hace eco de otros enclaves culturales. La evaluación crítica de las distintas inteligibilidades que coexisten al interior de una sociedad debe hacerse recurriendo a inteligibilidades alternativas y no existe ningún modo de garantizar la superioridadúltima de la propia posición en algún fundamento extradiscursivo (como la "verdad"). De este modo, el diálogo entre las diversas inteligibilidades es visto como un debate en torno a las consecuencias que posee para la acción social la construcción del mundo desde principios diferentes.

Muchos otros elementos han sido estipulados en relación con el alcance teórico de esta propuesta (Pearce, 2005; Potter, 1998); sin embargo, todos ellos comparten el énfasis en el desplazamiento desde la metáfora del "espejo" a la del "taller de construcción”. Es precisamente este punto uno de los que ha resultado más controversial puesto que se ha cuestionado si el socioconstruccionismo aporta algo realmente nuevo al debate respecto de este tema o si, simplemente, repite de otro modo cuestiones que ya habían sido postuladas previamente y no es sino más de lo mismo. En lo que sigue trataremos de justificar la especificidad de este planteamiento, evaluando los aportes de los que se nutre y las líneas de novedad que en relación con ellos constituye.

\section{Socioconstruccionismo: tradición y novedad}

Una afirmación central del planteamiento socioconstruccionista tiene que ver con que el lenguaje no expresa categorías previamente definidas por el mundo (físico o social) sino que introduce en él distinciones que le son propias y que, en sentido estricto, son las que le dan forma. Evidentemente, esta es una idea que, desde el propio De Saussure, ha estado presente en toda la tradición estructuralista así como 
en los diversos tipos de constructivismo lingüístico formulados hasta la fecha; sin embargo, el construccionismo posee especificidad respecto de este planteamiento al menos en dos sentidos: en primer lugar porque, a diferencia del estructuralismo de raíz saussureana, no considera al lenguaje desde un punto de vista puramente abstracto (como un sistema estable de elementos y reglas de combinación) sino que lo concibe fundamentalmente como una práctica, como una forma de acción, al decir de Pearce, y, en este mismo sentido, porque al enfatizar el carácter relacional de la "acción discursiva” no concibe al significado como un componente de naturaleza cognoscitiva sino más bien como un emergente relacional. Ambas distinciones tienen importantes implicaciones para la propuesta construccionista, de modo que las analizaremos con mayor profundidad.

Respectodeloprimero, taly comoaclaró muy tempranamente Valentin Voloshinov (1992) una de las principales limitaciones del modelo desarrollado por De Saussure para la comprensión del lenguaje -al que denomina "objetivismo abstracto"-, tiene que ver con su énfasis en la lengua como sistema estable e invariable de formas normativas idénticas a sí mismas, que se imponen a la conciencia individual reduciendo sus actos a meras actualizaciones y refracciones, lo que lo lleva a desarrollar una perspectiva marcadamente filológica que privilegia los aspectos estáticos del lenguaje que surgen cuando éste es objeto de análisis, olvidando que su realidad fundamental no es ser vivido como algo externo y ajeno sino como algo propio y familiar, que se encuentra en un proceso de continua generación y que adquiere su entidad sólo en el marco operativo de las interacciones con los demás en el contexto de las situaciones sociales en curso.

El socioconstruccionismo hace propia esta crítica y se acerca más a posiciones como la desarrollada por la etnometodología a través del denominado "análisis conversacional" (Sacks, 1992) donde más que suponerse que el significado se encuentra garantizado en el sistema de la lengua, se analiza como éste es construido en el marco de las interacciones conversacionales concretas desarrolladas en la vida cotidiana, recurriendo para ello a una serie de técnicas y mecanismos retóricos (verbales, paraverbales u otros) que, dependiendo de su ajuste a la situación y contexto particulares, pueden resultar más o menos exitosas de cara al logro de los propósitos de los interactuantes al momento de utilizar dichas herramientas en la construcción de sus descripciones. Es el uso diferencial de éstos "recursos retóricos" y su adecuación a los diferentes escenarios sociales lo que explicaría que algunas descripciones sean validadas en el proceso de interacción social mientras que otras no lo son. Podríamos decir, parafraseando al propio Voloshinov, que el análisis conversacional parte de la base que a los hablantes no les interesa el lenguaje en tanto sistema sino que lo que les interesa ( $y$ hacen cotidianamente) es producir ciertos enunciados concretos, orientados a fines pragmáticos vinculados con las situaciones sociales en las que se encuentran involucrados y en el marco de las cuales lo que se dice y escucha no 
son palabras sino verdades o mentiras, halagos o insultos, etc. En este punto se hace evidente la influencia que sobre el construccionismo tiene, también, la teoría de los actos de habla con su énfasis en el carácter ilocucionario y pragmático del lenguaje.

En lo concerniente al segundo punto (que podríamos denominar como el problema del significado), aunque evidentemente comparte con tradiciones teóricas como los constructivismos lingüísticos (Whorf, Sapir, Fowler o Grace) o el constructivismo radical (von Glasersfeld, von Foerster o el propio Maturana) la idea de que el lenguaje juega un rol esencial en el tipo de representación del mundo que llegamos a tener, estos últimos conciben dicha representación como una construcción individual de carácter cognoscitivo lo que, en última instancia, los conduce a diversas formas de solipsismo en las que se garantiza un status ontológico propio, aunque independiente e inconmensurable, tanto al mundo como a la mente individual. El construccionismo social, por el contrario, enfatiza el carácter comunitario que poseen dichas representaciones y los significados a ellas asociados rechazando, de paso, el dualismo que se encuentra a la base del planteamiento constructivista, puesto que a su juicio: "los conceptos con los que se denominan tanto el mundo como la mente son constitutivos de las prácticas discursivas, están integrados en el lenguaje y, por consiguiente, están socialmente impugnados y sujetos a negociación” (Gergen, 1996, p. 94).

En relación con las proposiciones que el construccionismo elabora respecto de la representación y el problema del significado resultan especialmente importantes los trabajos del denominado "segundo Wittgenstein" a partir de conceptos como los de "juego de lenguaje" y "forma de vida" que enfatizan fuertemente las funciones relacionales del lenguaje y el carácter permanentemente móvil y, en última instancia, indecidible del significado. A diferencia de la óptica tradicional que ve al significado como algo relativamente estático, asociado a ciertos términos particulares y existiendo de un modo completo en el reino inaccesible de lo mental antes de que un enunciado cualquiera sea proferido, para Wittgenstein (1988) el significado de las palabras corresponde más bien al uso concreto que de ellas hacemos en el contexto de nuestras interacciones cotidianas; como dichos contextos pueden ser variados y los fines establecidos diversos, las palabras no poseerían un significado único y claramente delimitado sino, más bien, una "familia de significados" relacionados entre sí y cuya determinación dependerá de los juegos de lenguaje específicos en que son usadas. La idea de "juego de lenguaje" busca dar cuenta del proceso global de utilización de las palabras y a través de él se designa "al todo formado por el lenguaje y las acciones con las que está entretejido” (Wittgenstein, 1988, p. 25), poniendo de relieve el hecho de que "hablar el lenguaje forma parte de una actividad o de una forma de vida" (Wittgenstein, 1988, p. 39).

Es la aplicación de este conjunto de ideas la que explica tanto la postura declaradamente anticognoscitivista del construccionismo social como el énfasis que 
pondrá sobre los procesos microsociales: al rechazar las premisas del pensamiento dual, el construccionismo focalizará sus intentos de explicación sobre lo que ocurre en el plano de la interacción, plano en el cual el lenguaje jugará un rol instituyente puesto que los significados que se construyan negociadamente dentro de los contextos de interacción, nos servirán tanto para constituir nuestras comprensiones del mundo como aquellas que se refieren a nosotros mismos. En este sentido, el construccionismo trabajará sobre la idea de que dichos significados se construyen en el marco de patrones de interacción, situados microsocialmente pero enmarcados e insertos en el espesor de la historia y la cultura.

\section{Construccionismo y medios de comunicación}

La consecuencia más importante que tiene asumir una perspectiva socioconstruccionista para el estudio de los medios de comunicación es, evidentemente, elabandonodetodapretensióndeutilizarlanocióndecorrespondencia como criterio de análisis, ya sea explícita o implícitamente. Esto es algo que no resulta del todo sencillo puesto que se trata de un supuesto profundamente arraigado y con un valor axiomático que, tal y como señalan Blackman y Walkerdine (2001), no sólo es parte de la visión de mundo de quienes investigan profesionalmente en este campo sino también del público en general para quien los medios constituyen la principal, cuando no la única, fuente de obtención de información respecto de la "realidad" ayudándoles a mantener una visión organizada, coherente y comprensible respecto del mundo y su, la mayor parte de las veces, caótico devenir.

El análisis construccionista se centrará más bien en la forma en que los medios de comunicación construyen discursos acerca de la realidad social, discursos que construyen, ellos mismos, la propia realidad a la que se refieren. Por lo tanto, estamos delante de una operación doble: los discursos construyen la realidad y son, a su vez, ellos mismos construidos.

Una aclaración muy importante respecto de esta afirmación fundamental tiene que ver con que, evidentemente, no supone que cualquier cosa que digan los medios adquirirá, por ese sólo hecho, estatuto de realidad factual: como cualquier otro, el discurso de los medios puede ser más o menos exitoso, más o menos afortunado, o más o menos eficiente en el logro de sus propósitos. Esto principalmente porque al interior de la sociedad, la agencia (entendida como capacidad performativa) se encuentra distribuida diferencialmente entre distintos espacios e incluye a diferentes tipos de actores sociales cada uno de los cuales desarrolla sus propias estrategias discursivas, de modo que el discurso de los medios debe insertarse dentro de esta compleja trama y, al interior de ella, se encuentra sujeto a sanción y puede ser objeto de impugnaciones de distinto tipo (y muchas veces lo es). Esta red impone límites a 
lo que puede ser dicho por los medios de comunicación o, al menos, a lo que pueden decir sin arriesgar su posición (de privilegio) al interior de la sociedad, estableciéndose en torno a ella un complejo sistema de apoyos y complicidades mutuas, así como de socavamientos y rivalidades que pueden ser más o menos deliberadas y más o menos estables en el tiempo, y que dan origen a toda una jerarquía de privilegios y servidumbres. Parte de estas restricciones surge de las vinculaciones diferenciales que, de hecho, los diversos medios mantienen con distintos sectores de la sociedad lo que les lleva a tomar posiciones divergentes e incluso antagónicas respecto de muchos temas y a mantener una relación intertextual crítica.

Por otra parte, tampoco se afirma que dentro de este heterogéneo sistema todos los discursos tengan el mismo valor ni el mismo peso; a través del proceso histórico- cultural algunos de ellos han sedimentado y se han vuelto hegemónicos, constituyendo lo que Foucault (1991) ha denominado "régimen de verdad" y es sobre este trasfondo, sobre este régimen, que los medios de comunicación deben elaborar sus propios discursos y desarrollar sus modalidades enunciativas particulares. Por supuesto, no todos los géneros discursivos funcionan en un registro realista ni buscan convencernos de que lo propuesto por ellos es "verdadero" en el sentido convencional que usualmente damos al término; sin embargo, en todos ellos se encuentran implícitas formas de entender "la realidad" y, con distintos niveles de estructuración, el trasfondo histórico-cultural aparecerá organizando y estableciendo las (móviles) fronteras de lo decible en esos otros registros.

Así, cuando se afirma que la realidad le impone sus contenidos a los medios o, dicho más teóricamente, que éstos poseen un carácter indexical, lo que en rigor observamos es que una parte de estos vínculos sociales y discursivos (y algunas veces todos a la vez) comienza a actualizarse con mayor fuerza y a interpelar (directa o indirectamente, explícita o implícitamente) de un modo más vehemente y desde distintas posiciones al sistema de medios para que incluya un determinado tipo de discursividad dentro de sus contenidos programáticos: la realidad, entendida como algo externo e independiente de nosotros, no impone ni podría imponer límites a los productos elaborados por los medios de comunicación, dichos límites surgen al interior de las relaciones sociales y discursivas en que ellos se encuentran inmersos. Del mismo modo, cuando se afirma que los medios "distorsionan la realidad" lo que tenemos delante, en última instancia, es el resultado de una tensión que surge entre diversas modalidades de representación emanadas desde posiciones discursivas diferentes, cada una de las cuales posee consecuencias pragmáticas distintas de cara a las formas de acción social en las que se encuentran implicadas: el problema vuelve a ubicarse no en la relación entre los medios y la realidad sino a nivel de las relaciones sociales que se establecen.

Analicemos lo anterior con mayor detalle puesto que es uno de los puntos en que puede apreciarse de un modo más nítido las diferencias que existen en los modos de 
aproximarse a estos problemas entre lo que podríamos denominar la óptica clásica (representacionista-realista) y las perspectivas de corte socioconstruccionista.

Consideremos, por ejemplo, lo que se afirma en relación con los prejuicios: una de las críticas más frecuentes que se dirigen hacia los medios de comunicación es que a través de ellos se difunden visiones estereotipadas y prejuiciosas de determinados grupos o categorías de personas (los homosexuales, las minorías étnicas, los discapacitados, los jóvenes, etc.), dichas visiones -ya sea porque son parciales o porque derechamente presentan información considerada como falsa- distorsionarían el verdadero ser de estos grupos reduciéndolo a algunas de sus características negativas. El supuesto que opera a la base de este tipo de afirmaciones es que dichos grupos o categorías de personas tendrían un "ser verdadero" que podría ser captado, conocido y, luego, reflejado de forma prístina (es decir, en su esencia) a través de las formas de enunciación propias de los distintos formatos mediáticos: el error (o la culpa) del medio radicaría, pues, en que por diversos motivos (políticos, religiosos, económicos u otros), interesada o involuntariamente, tergiversa esta imagen y provoca, entre un público altamente influenciable, una respuesta negativa hacia esos grupos.

Desde el punto de vista del socioconstruccionismo dicho argumento resulta tremendamente problemático, al menos por dos motivos. En primer término, porque reifica a la identidad y la trata como un objeto real, como una entidad que posee unas ciertas características que le son propias, que es anterior a las relaciones sociales y al propio lenguaje, que habita en el reino inaccesible de lo interior-íntimo y que es el punto de explicación última de toda la conducta; aunque no tenemos demasiado espacio para detenernos en este interesante debate, las perspectivas construccionistas y discursivas problematizarán el supuesto de que exista una naturaleza humana semejante (anterior a toda actividad significativa, que sea inamovible y que esté localizada en el interior humano), considerando a la subjetividad, en cambio, como íntegramente constituida a través del lenguaje y en el espacio de la interacción: de ser una estructura cognitiva, el "Yo" pasará a ser considerado como una estructura relacional-discursiva, como una narración (Potter y Wheterell, 1987).

En segundo lugar, porque oscurece el importante rol que los propios medios juegan en la producción de esas y otras identidades, como parte de un amplio sistema de significación al interior del cual se generan representaciones de género, raza, edad, posición social, etc.; obviamente, más que de identidades completas y totalmente coherenciadas estamos hablando de identidades fragmentarias o, incluso, de lo que se ha dado en denominar "posiciones de sujeto".

De esta forma, el tema no es tanto que unas identidades sean distorsionadas por discursos prejuiciosos y discriminadores, sino más bien que dichos discursos actúan produciendo determinados espacios de subjetivación desde los que resulta posible entenderse a sí mismo y a los demás. Podrá objetarse que nadie utilizará una posición de sujeto negativa para comprenderse a sí mismo; sin embargo, y aunque 
esto no es totalmente correcto (basta con observar lo que ocurre con el denominado movimiento queer), lo importante es considerar que, tal como señalan Rose (1998) o Blackman y Walkerdine (2001), muchos de estos discursos lo que buscan es afirmar un conjunto de identidades normalizadas a partir de una definición negativa de ciertas diferencias y la patologización del otro y la otredad, generando, de esta forma, un ideal regulativo que organiza la aparente fragmentación identitaria poniéndole límites.

\section{Medios de comunicación y relato factual}

Hasta aquí hemos revisado algunos argumentos sobre por qué resulta inapropiado desde el punto de vista teórico y epistemológico utilizar la metáfora de la correspondencia con la realidad para estudiar a los medios de comunicación. Evidentemente, esto no obsta para que los medios sigan hablando como si simplemente describieran la realidad y reflejaran lo que allí pasa, ni para que sus discursos tengan dentro de la sociedad "efectos de verdad".

La óptica tradicional (realista-representacionista) suele presentar dicha operación de descripción de los hechos sociales de un modo bastante simple y aproblemático: los medios de comunicación envían un emisario (típicamente un periodista) para aproximarse a algún hecho de interés particular, éste lo observa, lo registra utilizando las tecnologías existentes para dicho propósito y, posteriormente, vuelve al medio donde el material es reproducido poniéndolo a disposición del público. Sin embargo y tal como la propia investigación en el campo ha demostrado ampliamente, las cosas no son tan sencillas: el enviado del medio pone atención en algunos aspectos y minimiza u omite otros de modo que la situación pase de simple "hecho" a "hecho noticioso", luego, cuando vuelve al medio, el material en bruto es editado de modo que se ajuste tanto a las exigencias editoriales (valóricas, políticas u otras) como a las formales (que, en general, suponen dar al material la forma de una narración coherente) en un proceso que puede tener varias etapas y que contempla la eventualidad que el hecho sea desechado, posteriormente se decide el lugar y la prioridad del hecho entre el conjunto de otros hechos disponibles para, finalmente, emitir el material debidamente sancionado. Y esto es sólo el comienzo puesto que, además de estas operaciones simples pueden identificarse otras mucho más complejas como las descritas por Vilches (1989) en relación con la construcción de la noticia televisiva, o las evidenciadas por Sunkel (2000) respecto del "régimen de autocensura" que caracterizaría parte de las rutinas que conforman la práctica periodística o la misma idea de "mundos posibles" y "verosimilitud" elaborada por Rodrigo Alsina (1996), sólo por mencionar algunas.

Dicho conjunto de operaciones (énfasis, omisiones, estilizaciones, etc.) dan cuenta con claridad que más que frente a un proceso de reproducción estamos delante de una 
cadena de producción: entre el "hecho social” y su "representación mediática” existen una serie de mediatizaciones que no garantizan ni pueden garantizar de ningún modo la existencia de un isomorfismo inequívoco. Lo que ocurre es que en este proceso productivo se verifican una serie de operaciones retóricas que dan origen a uno de los elementos más interesantes del discurso elaborado por los medios de comunicación que es lo que algunos autores han denominado "relato factual" y que no es sino aquel tipo de narración que se presenta a sí misma como si fuera una simple descripción o un discurso empírico.

Tendemos a pensar que, más allá de cualquier suspicacia, las descripciones buscan de un modo acabado o imperfecto o incluso "construido", dar cuenta del mundo, es decir, que su valor se juega esencialmente en lo que Austin denominó su capacidad referencial o constatativa. Uno de los autores que más ha investigado este tipo de discurso es Jonathan Potter quien ha cuestionado que este carácter constatativo de las descripciones sea su aspecto más relevante; a su juicio, las descripciones tienen ellas mismas una orientación a la acción, es decir, más que dar cuenta de cosas muchas veces lo que se busca por medio de ellas es que ocurran determinadas cosas en contextos que, por diversas razones, resultan complejos. Para graficar este hecho, recurre al siguiente ejemplo cotidiano (Potter, 1998, p. 143):

Becky: $\quad$ oi (.) sh shh (.) quizás haya sido eso

Neil:NO eso no hace ningún ruido

Alan: $\quad[$ no (.) ha sonado fuera $(0,4)$ seguro que ha sonado fuera $\rightarrow$ Diane: $\quad$ Neil, tú llevas los zapatos puestos

Claramente, la última afirmación de Diane, aunque aparece como una mera descripción, es una invitación a su compañero para que explore el origen del misterioso ruido, evitando hacerlo ella misma. El contexto es complejo porque al endosar la responsabilidad en otros (por ejemplo, mediante una solicitud explícita) podría haber sido acusada de flojera o cobardía, de modo que utilizar una descripción de este tipo le permite focalizar la discusión en un aspecto "exterior" y "objetivo".

Lo anterior nos reenvía a otra característica que Potter identifica en los discursos factuales y que dice relación con que éstos aparecen construidos como exterioridades, es decir, como discursos que sobrepasan el ámbito de la acción posible de los enunciatarios ubicándose sin más en el mundo, de modo tal que "las expectativas se trasladan desde el productor del relato factual hasta la entidad que se está constituyendo" (Potter, 1998, p. 143). La construcción de este tipo de exterioridades supondría el despliegue de una serie de estrategias como la utilización de enunciados empíricos, formas impersonales, inclusión de detalles, adecuada focalización del relato, etc. 
Sin embargo, los relatos, por factuales que sean, siempre pueden estar sujetos a crítica existiendo dos estrategias especialmente corrosivas a este respecto: por una parte, la identificación de determinados intereses asociados a quien hace la descripción (lo que el propio Potter denomina como el "dilema de la conveniencia") y, por otra, el socavamiento de ciertas categorías de enunciadores que sirven para sostener el relato. Respecto de lo primero, existen numerosos estudios (que abarcan desde aquellos realizados en el área del cambio de actitud hasta la etnometodología) que dan cuenta que la credibilidad de una fuente de información pasa por el establecimiento de su "independencia" respecto de los "hechos" relatados y los agentes en juego (por ejemplo, a menor cercanía respecto de las partes mayor credibilidad tiene un testigo). Respecto de lo segundo, habitualmente la corroboración del carácter fáctico de un relato pasa por la participación que tienen en su constitución cierto tipo de actores que pertenecen a categorías tales como "testigo", "experto", "autoridad", "líder", etc., de modo que si es posible socavar la pertenencia del actor a la categoría establecida, inmediatamente su credibilidad se verá debilitada y su relato desacreditado (total o parcialmente).

De este modo, lo que para la óptica construccionista se transformará en el foco de atención al momento de analizar el discurso de los medios, será cómo éstos adquieren un determinado estatuto al interior de la sociedad: de qué apoyos se valen, qué modalidades de enunciación se utilizan, qué contenidos específicos se articulan, qué tipos de sujetos se constituyen, qué operaciones discursivas se actualizan, en síntesis, que régimen de representación se conforma y cómo éste impacta en la constitución social de la subjetividad.

Es por este motivo que el foco de nuestro trabajo no se centra en la comparación entre un sujeto real y un sujeto representado (o distorsionado) por los medios, ni pretende desenmascarar los sesgos existentes en la descripción de los hechos comparándolos con la textura de una realidad incontrovertible. Más bien busca comprender cuál es el espacio representacional que se configura a partir del discurso periodístico, qué tipo de ideales regulativos produce, qué coordenadas entrega para comprenderse a sí mismo y a los demás y para constituirse en un determinado tipo de sujeto y de qué apoyos se vale para presentar su discurso como un discurso de tipo factual, esto es, para decirlo en términos focaultianos, como un discurso que tiene efectos de verdad.

\section{Epílogo: Socioconstruccionismo, críticas y limitaciones}

Como puede apreciarse, el socioconstruccionismo constituye una alternativa teórica polémica y, como tal, ha suscitado diversas críticas (algunas de las cuales fueron esbozadas previamente). Antes de finalizar, quisiéramos dedicar un breve espacio a 
aquella que a nuestro juicio resulta más interesante, en tanto señala los límites de las posibilidades analíticas abiertas por el socioconstruccionismo y que dice relación con que su énfasis en el discurso como única (y última) forma de determinación y como punto primario (y virtualmente exclusivo) de fijación de la subjetividad lo lleva a olvidar otras formas de determinación y lo conduce a un reduccionismo lingüístico cercano al idealismo.

Tal como señalan Ema, García y Sandoval (2003) la perspectiva construccionista nos presenta al mundo como si fuera consecuencia única y exclusiva de nuestras formas de referirnos a él, es decir, nos propone que "el mundo no es independiente de nosotros pero nosotros sí somos independientes del mundo” (2003, p. 77), omitiendo con ello el hecho que el trasfondo que genera las condiciones de posibilidad para la producción de una determinada representación es de carácter semiótico pero también, y de modo muy importante, de tipo material. Lo anterior no supone considerar dicho trasfondo como una esencia ahistórica o intemporal (como ocurre con el realismo ingenuo) sino más bien como "un proceso en el que se articula una red de agencias humanas y no-humanas que se (re)construyen mutuamente" (Ema, García y Sandoval, 2003, p. 76): el trasfondo no sólo supone la existencia de determinadas sedimentaciones lingüísticas sino también materiales (prácticas no lingüísticas, tecnologías, etc.) todas las cuales generan constricciones de diverso tipo.

Aplicado al campo de los medios, lo anterior significa que resulta necesario considerar no sólo los aspectos lingüísticos de las representaciones elaboradas por los medios sino también, por ejemplo, cuestiones como la compleja relación que se establece entre la incorporación de innovaciones tecnológicas y la emergencia de nuevos lenguajes y posibilidades de expresión y representación impensables hasta ese momento. Entonces, la idea de lo "post", que aparece reflejada cautamente entre paréntesis en el título de este artículo, sólo busca indicar que el socioconstruccionismo no es un punto de llegada final, ni clausura la discusión teórica y epistemológica, sino que es un lugar de arranque desde el cual debe ser posible tensionar permanentemente los límites de dicha discusión. 
SEGUNDA PARTE

\section{TELENOTICIARIOS, DISCURSO PERIODÍSTICO Y SUJETO DELINCUENTE: RESULTADOS DE INVESTIGACIÓN}




\section{Capítulo 4 LA INVESTIGACIÓN}

Corresponde ahora revisar los resultados de la investigación que da origen al presente volumen. Ella tuvo como objetivo principal describir cuáles son las estrategias de veridicción que se despliegan al interior de los telenoticiarios, es decir, qué operaciones son llevadas a cabo para presentar los discursos que ellos producen como discursos factuales, como discursos de verdad. Con este propósito se analizó un caso que, por la cobertura de que es objeto, por su relevancia social y por lo exitosa que ha resultado la estrategia mediática en la materia resulta ejemplar: el de la delincuencia y la figura del sujeto delincuente.

\section{Diseño metodológico}

Los objetivos específicos que guiaron el desarrollo de la investigación fueron los siguientes:

1. Conocer la presencia y cobertura que las noticias relacionadas con la delincuencia y el sujeto delincuente tienen en los noticiarios televisivos de cobertura nacional.

2. Identificar la representación del sujeto delincuente construida por los noticiarios televisivos y describir sus principales características.

3. Determinar los vínculos y las formas de articulación existentes entre la representación del sujeto delincuente y otros temas presentes en el discurso de los noticiarios televisivos (temor, violencia, pobreza y consumo de drogas, entre otros).

4. Establecer las estrategias discursivas a través de las cuales, dentro del discurso de los noticiarios de televisión, dicha representación es dotada de un estatuto de objetividad e insertada en un régimen de verdad, determinando los puntos de apoyo en que se basan dichas estrategias.

Para el cumplimiento de estos objetivos, el diseño metodológico contempló una muestra de los noticiarios centrales de los cuatro canales con cobertura nacional: Televisión Nacional de Chile, Canal 13, Megavisión y Chilevisión. Las semanas en que se recogió dicha muestra fueron las siguientes (todas corresponden al año 2007):

1. 02 al 08 de enero

2. 12 al 18 de febrero 
3. 19 al 25 de marzo

4. 23 al 29 de abril

Como resultado de esta etapa se obtuvo un total de 112 emisiones (4 noticieros por día en 28 días), que representan 102 horas de transmisión ${ }^{7}$ al interior de las cuales pudo identificarse un total de 1963 noticias. Este corpus fue sometido a un análisis en dos etapas:

- La primera, de carácter cuantitativo, buscó caracterizar a los noticiarios televisivos en dimensiones tales como: el tiempo que dedican a publicidad, la cantidad de noticias que incluyen, la duración de cada segmento y la cobertura dada a las noticias relacionadas con la delincuencia y el sujeto delincuente.

- La segunda, consistió en un análisis cualitativo de aquellas noticias relacionadas con la delincuencia y el sujeto delincuente cuyo propósito fue determinar el tipo de representación mediática que ellos construyen en torno a la figura del delincuente e identificar las estrategias de veridicción sobre las que dicho discurso está soportado y que le otorgan un estatuto de realidad.

\section{La dimensión cuantitativa: cobertura y presencia del sujeto delincuente en los telenoticiarios}

En el presente apartado se entregan los resultados obtenidos luego de realizada la primera etapa de análisis y que permiten caracterizar el espacio discursivo de los noticiarios televisivos de los canales que poseen cobertura nacional, estableciendo las principales continuidades y diferencias que se verifican entre ellos así como los énfasis desde los cuales constituyen la agenda noticiosa.

Dicho análisis se realizó a partir dos variables básicas:

a. La cobertura, entendida como el número total de noticias dedicadas a cada segmento y el porcentaje que ellas representan del total de noticias incluidas en cada noticiero.

b. La presencia, entendida como el tiempo total (medido en segundos) que cada noticiario dedica a los diferentes segmentos que lo constituyen.

De este modo, el análisis se sucede en tres partes:

- En primer lugar,se traza una contextualización del escenariogeneral pesquisado

7 Todos los noticiarios tienen una hora de duración (de 21:00 a 22:00 horas) excepto el de Mega que de lunes a viernes duraba 30 minutos (de 21:00 a 21:30 horas), extendiéndose los días sábado y domingo a 1 hora. 
(cobertura y presencia de las noticias referidas al sujeto delincuente, en relación a las demás áreas temáticas del noticiario).

- A continuación se aterriza sobre los hechos noticiosos específicos (aunados como "subtemas") en los que se articula cobertura y presencia del sujeto delincuente, y desde allí comentar las disposiciones observables desde tal desagregación.

- Finalmente, se presentan las principales conclusiones emanadas en la medición.

\section{a. Tiempo dedicado a la publicidad}

Tal y como puede observarse en el Gráfico 1, el tiempo dedicado a la publicidad durante la emisión de los noticiarios centrales es bastante similar entre los distintos canales. Sin embargo, desde un punto de vista proporcional el noticiario que más publicidad posee es Meganoticias, con casi un 29\% del tiempo dedicado a anuncios, seguido por Teletrece, con casi un $17 \%$ del total del tiempo dedicado a publicidad, luego por 24 horas con un 16\% y, finalmente, por Chilevisión Noticias con un 15\%.

\section{GRÁFICO 1}

Relación promedio (segundos) entre tiempo de información y tiempo de publicidad por $\mathrm{Canal}^{8}$

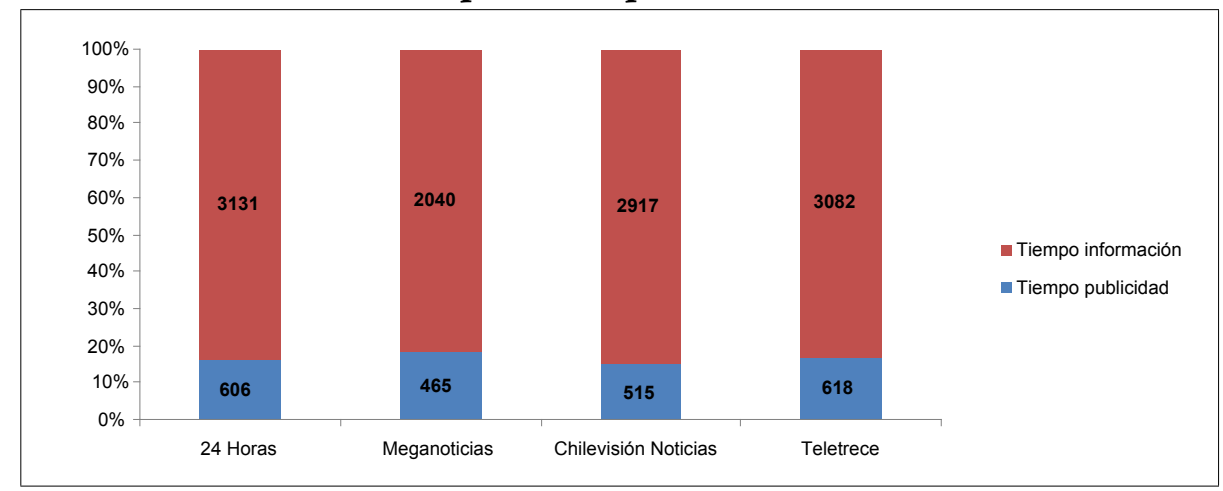

Si ahora nos detenemos a revisar el tiempo que ocupa la publicidad en cada período muestral, podemos observar que la semana con más publicidad promedio para todos

8 Fue considerado como variable "publicidad" el espacio dedicado a publicitar productos, incluso dentro del propio formato del telediario. De tal forma, se tomó en cuenta los comerciales que dividen el programa, más los tiempos al comienzo y al final de la presentación, como asimismo de los auspiciadores. 
los canales es la correspondiente al mes de abril. La situación parece ir descendiendo si pensamos que luego se ubica la semana de marzo y antes la de febrero, con el menor tiempo de publicidad. No obstante, el período de enero experimenta una leve alza respecto de febrero, situación que probablemente esté explicada por el inicio del período de vacaciones. El gráfico 2 da cuenta de esta situación:

\section{GRÁFICO 2}

Relación promedio (segundos) entre tiempo de información y tiempo de publicidad por período muestral

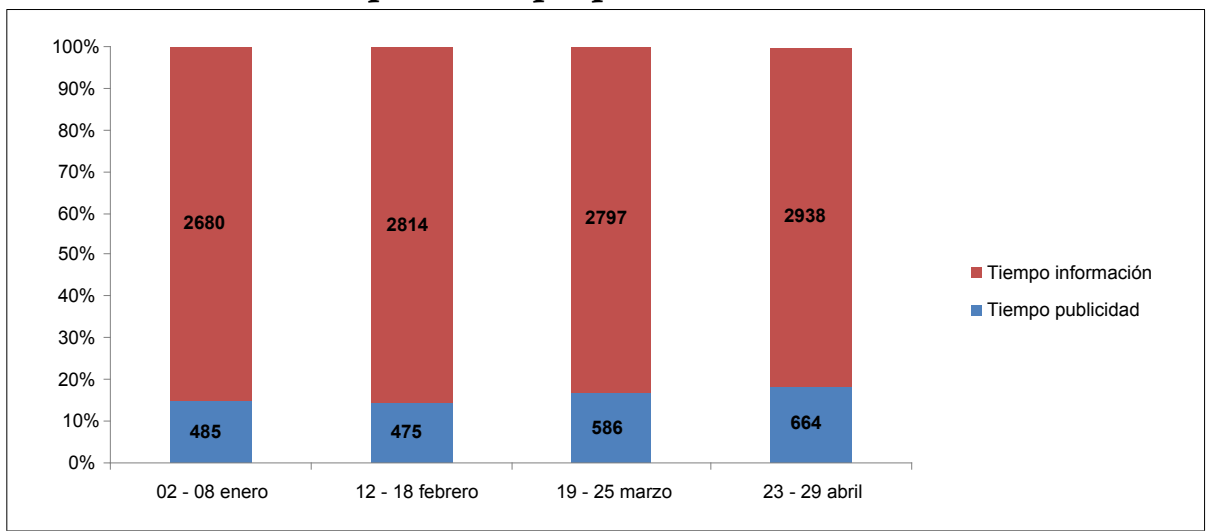

Si se considera, ahora, la distribución del tiempo destinado a publicidad por día de la semana es posible observar que los días viernes y sábado son los que concentran una mayor proporción de tiempo dedicado a anuncios, disminuyendo dicha proporción progresivamente mientras se retrocede hacia el día lunes, no obstante las variaciones aparecen como poco significativas, tal y como puede apreciarse en el gráfico 3.

\section{GRÁFICO 3}

Relación promedio (segundos) entre tiempo de información y tiempo de publicidad por día

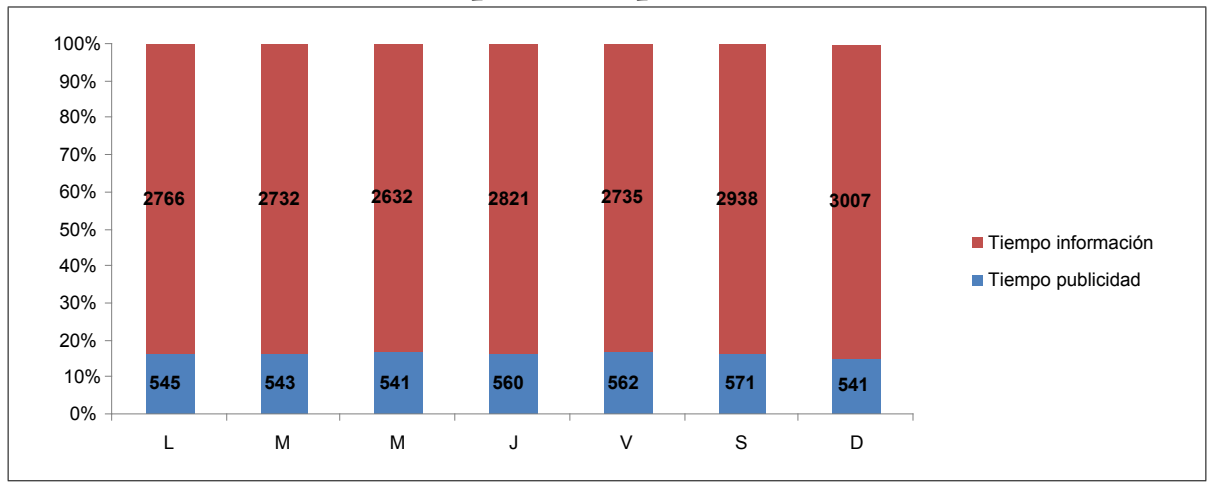




\section{b. Cantidad promedio de noticias ${ }^{9}$}

Para observar de qué manera se comporta el tiempo no publicitario del noticiario realizamos un promedio simple del número de notas de cada emisora, tal como se ve en el gráfico 4, y una comparación del total por períodos de tiempo, según indica el gráfico 5 .

\section{GRÁFICO 4}

Número total de notas según canal

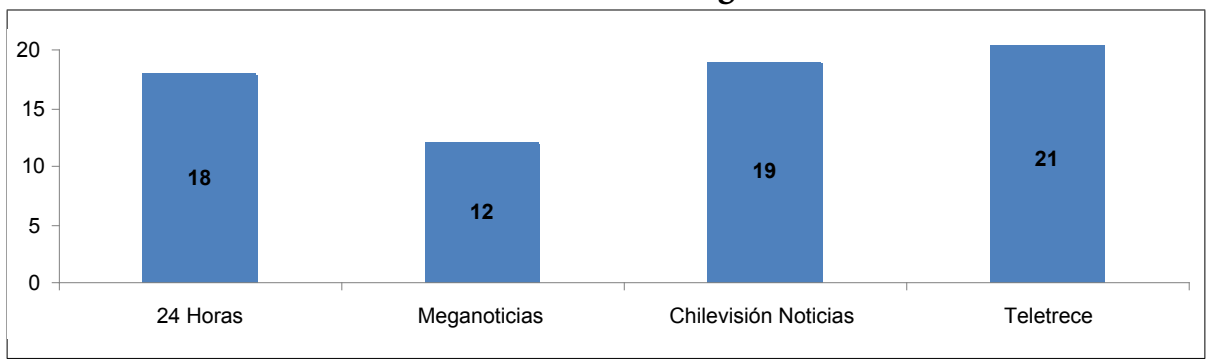

En torno al primer gráfico vemos que las dos grandes cadenas nacionales -Televisión Nacional, con 24 Horas, y Canal 13 con Teletrece- son quienes producen más notas en sus tiempos regulares, junto a Chilevisión Noticias. En tanto, Meganoticias es quien menos notas presenta, con un promedio de 12 por día. Por contrapartida, Teletrece resulta ser quien más notas propone en su noticiero central. $\mathrm{Si}$ a eso ahora sumamos lo que muestran los períodos muestrales, podemos decir que el mes con más noticias fue febrero, con un promedio de 19. Luego se ubican enero y abril con un índice de 18 notas por día. Y en último lugar se encontraría la semana de marzo, con sólo 16 notas.

GRÁFICO 5

Número total de notas según período muestral

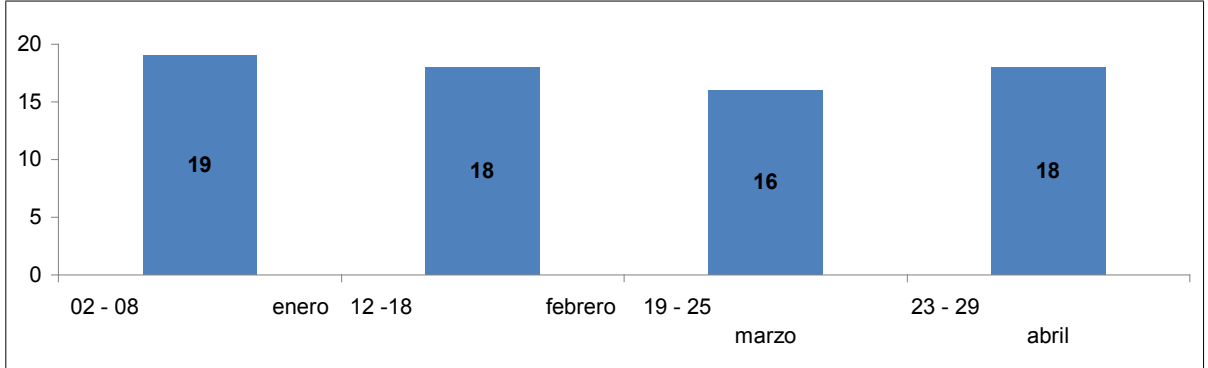

9 Las notas son consideradas como la unidad mínima de análisis. En términos de tiempo incluyen la locución previa del presentador y el trabajo editado y producido por los reporteros y periodistas hasta el corte final. Todo tipo comentario fue considerado una nota en sí misma. 
Finalmente el gráfico 6 nos permite apreciar que no existen grandes variaciones en el número de notas en función de los días de la semana, con excepción del día sábado donde se observa de modo consistente un aumento en el número de notas el que se eleva a 20, en circunstancias que el resto de la semana se mantiene entre 16 y 18.

\section{GRÁFICO 6}

Número total de notas según día

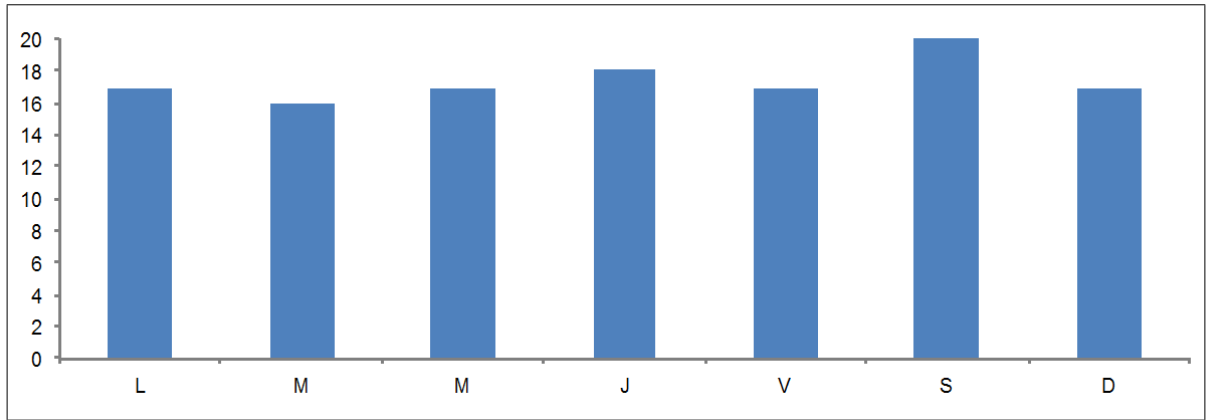

\section{c. Cantidad promedio de noticias según área temática ${ }^{10}$}

Pasando ahora a la distribución promedio de las notas según el área temática con la cual se identifican, puede establecerse un claro predominio de las noticias referidas a sociedad y/o cultura.

\section{GRÁFICO 7}

Número promedio de notas según telenoticiarios

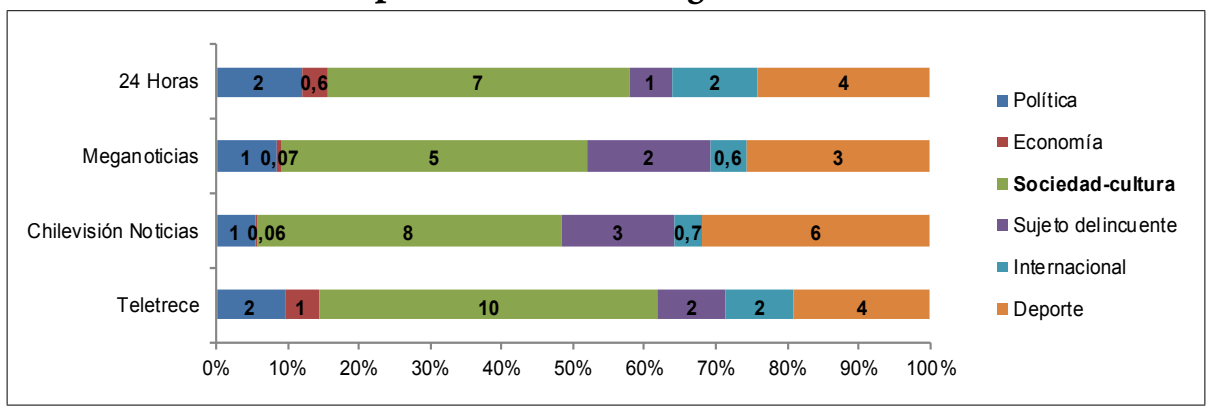

En todas las muestras -según telediario- se observa un notorio predominio de esta variable, junto al área dedicada a deportes. La complicación comienza cuando se

10 Las categorías fueron desarrolladas por el propio equipo de trabajo. 
ve que al desagregar la variable por canal los predominios no son tan claros. En el caso de Teletrece, el tercer lugar notas promedio la ocupa el tema política, al igual que los temas sobre sujeto delincuente. Lo mismo sucede en el caso de 24 Horas, con 2 casos promedio para cada área.

Para los otros dos emisores, Chilevisión Noticias y Meganoticias, la cuestión del sujeto delincuente está mucho más presente en su cobertura, posicionándose en un claro tercer lugar. El programa que más notas exhibe para nombrar la variable es Chilevisión Noticias, con 3 notas promedio por día, seguido de las noticias del área política, internacional, y una casi inexistente presencia de las noticias sobre economía.

GRÁFICO 8

Número promedio de notas según semana

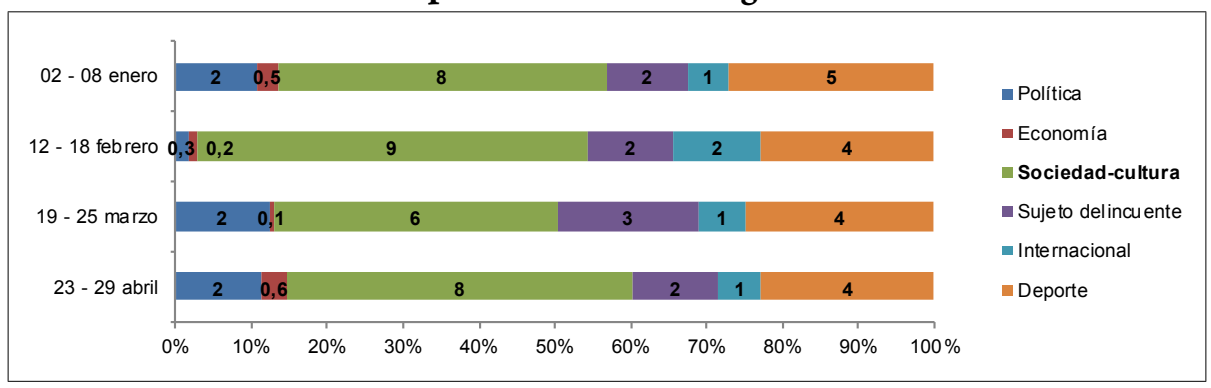

Ahora bien, si observamos la misma variable a partir de los períodos de pesquisa, tendremos que la distribución se mantiene en el número de notas dedicadas a cada tema. Sigue siendo predominante la presencia de las noticias cuyos contenidos aluden a temas sociales y/o culturales; luego, las noticias del área deportiva, sujeto delincuente y política en un status similar; más atrás internacional, y por último las noticias de economía.

Sin embargo, la distribución por períodos muestrales contempla matices: la semana de enero reflejará aquí un mes normal, con una distribución bastante parecida a lo descrito. Febrero, por su parte, aparecerá como el mes con mayor predominio de temas de sociedad y/o cultura, y con una casi nula persistencia de las noticias políticas. A su vez, la semana de marzo muestra una baja de la variable sociedad y/o cultura, y un repunte de la categoría sujeto delincuente, siendo el período que en promedio más presentó estas noticias. Abril nuevamente impone las cifras promedio, estabilizando la variable estudiada en un promedio de dos casos por día.

A partir de lo sugerido del eje de la sucesión semanal, las proporciones manifestadas para cada tema de la agenda noticiosa en las perspectivas anteriores aparecen aquí igualmente reflejadas. Así, el predominio de las noticias referidas a temáticas de sociedad y cultura es evidente, manejándose entre las 6 informaciones en promedio los días domingo (menor) y las 9 correspondientes a los días lunes. No 
obstante, precisamente el día domingo el protagonismo de las noticias referidas a esta área se ven un tanto mermadas por el avance, en términos proporcionales, de aquellas destinadas a cubrir asuntos deportivos ( 5 noticias en promedio).

\section{GRÁFICO 9}

Número promedio de notas según día

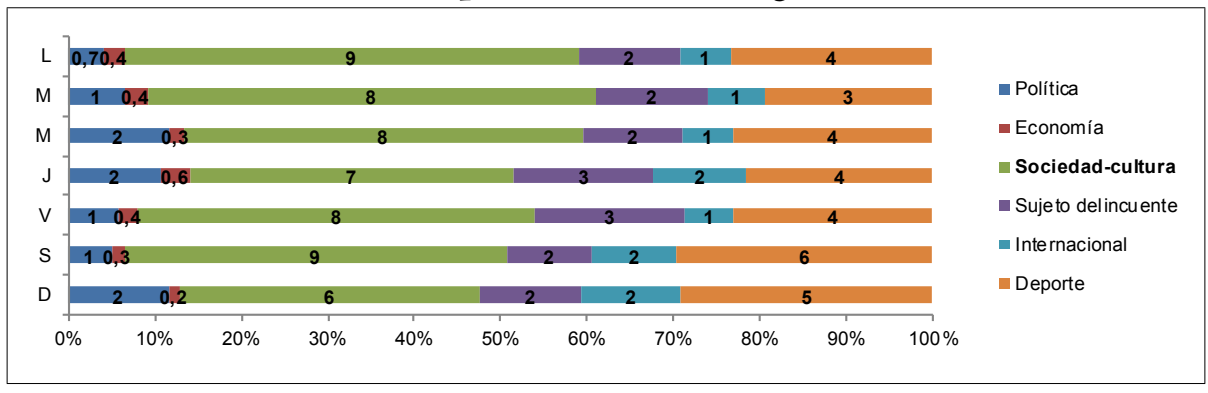

En este sentido, deporte vuelve a ser la segunda mayoría en términos de la cantidad de noticias incluidas, desplegándose para ello una cantidad que varía entre las 3 (martes) y 6 noticias (sábado). Lo mismo ocurre con las zonas internacional ( 1 a 2 noticias en promedio) y economía ( 0,3 a 0,6 informaciones).

Las noticias relacionadas con política, en cambio, son las únicas que manifiestan una cobertura menos regular: de las 0,7 notas promedio del día lunes, hacia el miércoles y jueves salta hasta 2; luego, vuelve a los índices de comienzo de semana, para levantarse nuevamente hacia la presencia de 2 noticias promedio, llegado el día domingo.

Finalmente, las informaciones referidas al sujeto delincuente experimentan la tendencia general de estabilidad: 3 notas los días jueves y viernes; y 2 durante los días restantes.

\section{d. Cobertura dada a la delincuencia y al sujeto delincuente ${ }^{11}$}

Pasando al objeto de estudio propiamente tal, nos encontramos con que existe una relación específica entre el tiempo que dedican los telediarios a la cobertura de noticias sobre el sujeto delincuente. Así, quien presenta un promedio menor de tiempo dedicado a este tema es 24 Horas ( 3 minutos y 4 segundos), seguido

11 Para efectos de captura, tomamos como criterio una definición operativa: el sujeto delincuente está presente, tácito o expresado, en aquellas acciones relacionadas con delitos de diferente tipo. Esta misma categoría será revisada y problematizada durante la etapa de análisis cualitativo de esta investigación. 
de Teletrece (4 minutos), Meganoticias (4 minutos y 17 segundos), y mucho más adelante, Chilevisión Noticias ( 7 minutos y 4 segundos).

Abrumadoramente superior, el tiempo dedicado a la sumatoria de los demás temas distinguidos no disminuye la importancia dela variable. Si consideramos que el tiempo restante se distribuye en una serie de contenidos diversos, la presencia proporcional del tiempo dedicado al sujeto delincuente resulta ser un pilar de la apuesta informativa de los canales. Al respecto, tanto Meganoticias como Chilevisión Noticias superan la barrera del 10\% del tiempo total de informaciones para sus emisiones (24 Horas y Teletrece se mantienen en el orden de entre el 6 y $8 \%$, respectivamente).

GRÁFICO 10

Relación promedio entre tiempo (segundos) referido al sujeto delincuente y no según telenoticiario

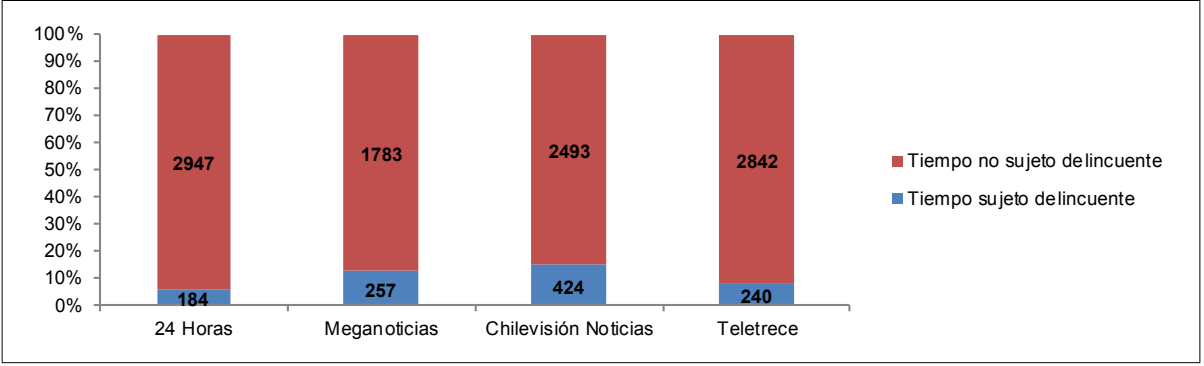

Lo anterior se captura aún más claramente si observamos los promedios de tiempo para cada semana abordada. De ello resulta que la semana de marzo (6 minutos y 6 segundos, elevándose una vez más por sobre el 10\% del tiempo total de informaciones) fue aquella donde más tiempo promedio se dedicó a la cobertura de la variable de estudio.

\section{GRÁFICO 11}

Relación promedio entre tiempo (segundos) referido al sujeto delincuente y no según semana

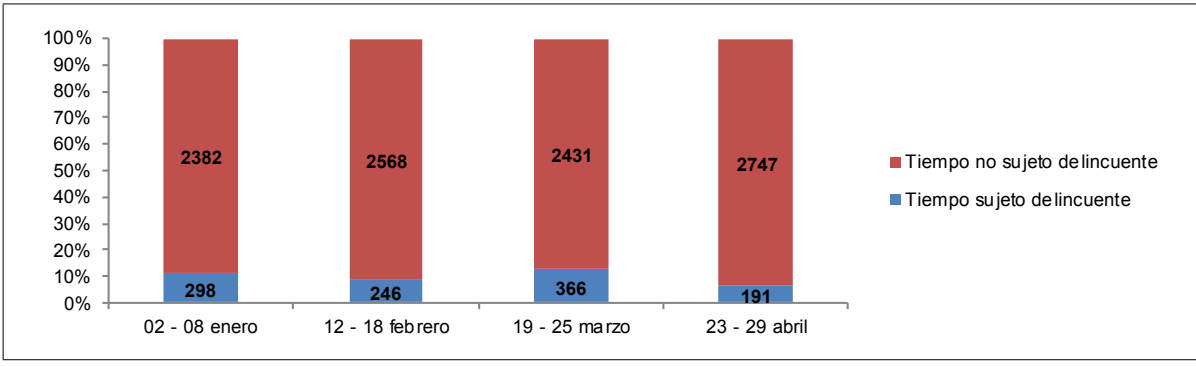


El segundo período promediado será la semana de enero (4 minutos y 58 segundos). Encontramos en tercer lugar en la semana de febrero (4 minutos y 6 segundos); y en valores menores se encuentra la semana de abril (3 minutos y 11 segundos). Estos dos últimos índices, en definitiva, se encuentran por debajo de la línea del 10\% del tiempo total de informaciones. Mientras, el período de enero fluctúa justo en el límite proporcional que hemos contemplado.

\section{GRÁFICO 12}

Relación promedio entre tiempo (segundos) referido al sujeto delincuente y no según día

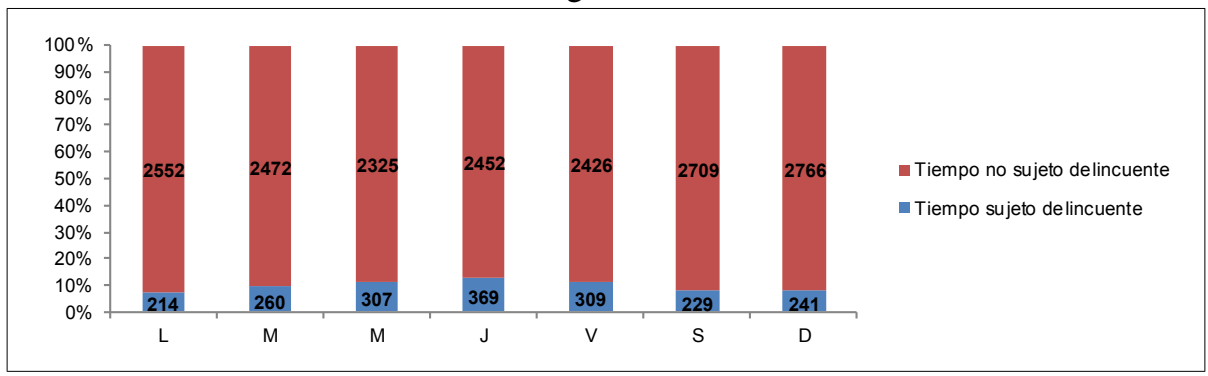

A partir del desarrollo semanal aparece también una tendencia: la presencia temporal promedio del sujeto delincuente observable durante los días lunes (3 minutos y 34 segundos) va ascendiendo progresivamente hasta encontrar su punto cúlmine los jueves (6 minutos y 9 segundos). Sábados y domingos, la suma vuelve a los niveles aproximados con los cuales se iniciaron, en promedio, las cuatro semanas de muestra.

Interesante es analizar dicha evolución a partir del mismo estándar porcentual comprendido para la observación de nuestra variable según telediario y semana-mes: del $8 \%$ del total utilizado durante los días lunes, los jueves esa cifra escala al orden del 13\%. Del mismo modo, el tiempo destinado a la sumatoria de las áreas noticiosas constituyentes del telediario se correspondieron con el crecimiento y caída del tiempo referido al sujeto delincuente, desarrollando -siempre en términos proporcionalesel ciclo inverso.

\section{e. Relación entre cantidad de notas (cobertura) y tiempo (presencia) dedicados a la delincuencia y el sujeto delincuente}

La pregunta que cabe hacerse, luego de comentar las dos series de gráficos anteriores, es si las variables números de notas y tiempo se comportan de la misma forma. Para esto cruzamos ambas variables según diferentes agregaciones. 
De acuerdo con el emisor, en el gráfico 12 vemos que se corresponde el número de notas de los telediarios con los tiempos promedios dedicados al sujeto delincuente. Así, Chilevisión Noticias tiene el más alto número de notas en promedio, con 3, y también la mayor dedicación temporal ( 7 minutos y 4 segundos). Por lo tanto, si estimamos una medida constante para la unidad "noticia” por parte de este exponente, resultaría que cada información se extendería aproximadamente por unos 2 minutos y 21 segundos.

\section{GRÁFICO 13}

\section{Relación cantidad de notas - tiempo según telenoticiario}

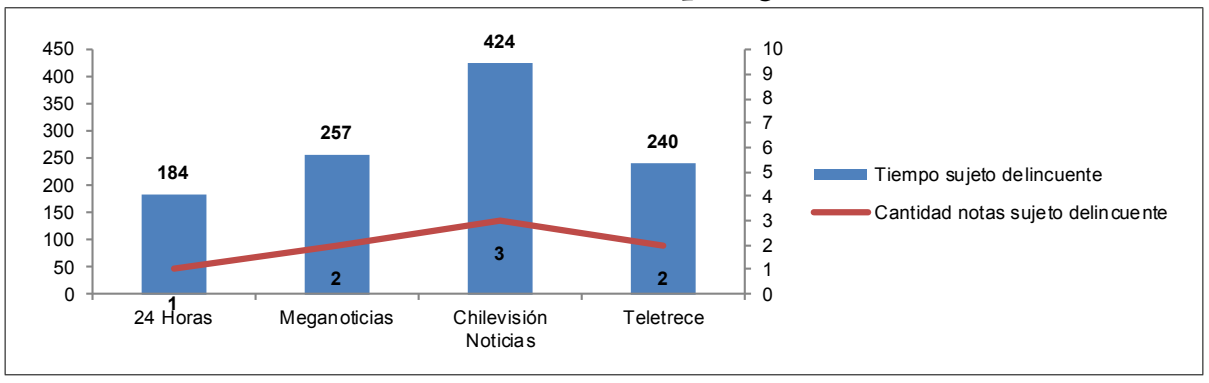

Teletrece y Meganoticias poseen un promedio de 2 notas por día, no obstante lo cual Meganoticias tiene 17 segundos más de presencia, totalizando 4 minutos y 17 segundos versus los 4 minutos promedio de Teletrece (recordemos que el tiempo total de informaciones promedio para uno y otro caso representan los extremos: Meganoticias con el menor; Teletrece, el más alto). Por último, el caso de 24 Horas, con un promedio de 1 nota por día, dedica 3 minutos y 4 segundos para ella. Muy similar al caso de Teletrece, y con sólo una diferencia de 56 segundos.

GRÁFICO 14

Relación cantidad de notas - tiempo según semana

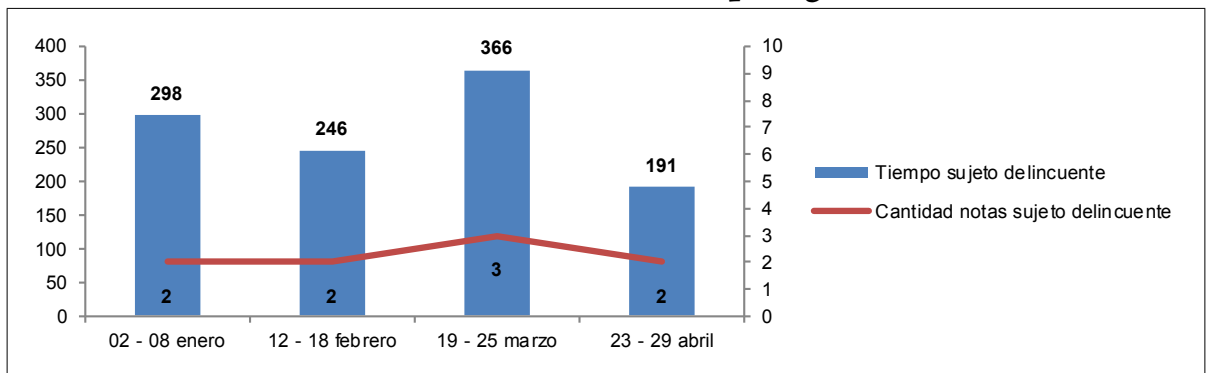

Si realizamos el mismo ejercicio pero ahora en torno a los períodos de muestra, veremos que existe una leve distorsión entre los números de notas y los tiempos que 
se dedicaron al tema. El primer período, la semana de enero, tiene como promedio 2 notas y 4 minutos con 58 segundos de presencia. Sin embargo, con esas mismas dos notas promedio se encuentran los meses de febrero y abril, aunque con registros temporales más bajos ( 4 minutos con 6 segundos, y 3 minutos con 11 segundos, respectivamente).

En el caso de la semana marzo, el claro predominio del tema se traduce en un aumento del número de noticias en los telediarios. Por ello es que encontramos 6 minutos con 6 segundos de presencia y 3 casos, en promedio.

\section{GRÁFICO 15}

Relación cantidad de notas - tiempo según semana

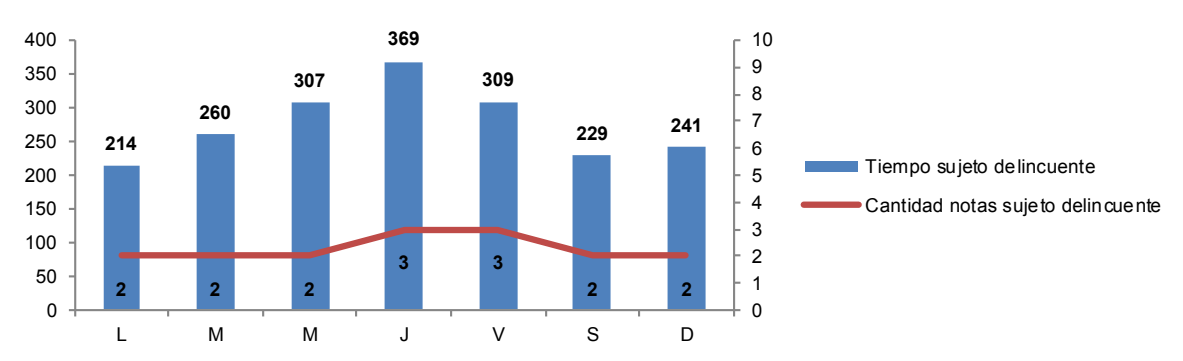

Llevado a un plano más específico, realizamos el mismo ejercicio pero en orden al promedio por día de la semana. De lunes a viernes se observa una curva que asciende hacia la mitad de la semana, y que tiene su punto más alto, como ya lo habíamos diagnosticado, el día jueves. Luego desciende de forma incremental, repuntando levemente el domingo. Al respecto, el estándar deducible del punto más alto se traduce en una noticia que establece 2 minutos y 3 segundos de duración.

Una cuestión similar sucede con el número de notas. Estabilizadas en 2 noticias se muestran los días lunes, martes, miércoles, sábado y domingo, realizando la misma curva incremental que en torno a la variable tiempo promedio. Sin embargo, y aún cuando hay dos días peak, con 3 notas promedio, existen claras diferencias de tiempo que no se condicen con el número de notas. En el caso del jueves y viernes -ambos con el mismo número de informaciones-, por ejemplo, existe 1 minuto de diferencia. En el caso de los días lunes, martes, miércoles, sábado y domingo las diferencias son más acentuadas, llegando a ser en su punto máximo del orden de 3 minutos y 11 segundos entre los días lunes y miércoles. 


\section{f. Cobertura promedio de temas/hechos noticiosos que aluden al sujeto delincuente ${ }^{12}$}

Realizando una agrupación de las notas pertenecientes a la variable controlada, y distribuyendo su cobertura según los temas o hechos mostrados en pantalla, observaremos una relativa coincidencia entre la mayor parte de las estaciones. En todas, la superioridad se la adjudica el subtema crímenes y/o homicidios, variando entre 1 noticia promedio por día en Chilevisión Noticias, seguido de cerca por un 0,8 noticia de Teletrece. En Meganoticias y 24 Horas la cifra se reduce prácticamente a la mitad con 0,5 y 0,4 noticias en promedio, respectivamente.

\section{GRÁFICO 16}

Cobertura promedio de temas/hechos noticiosos que aluden al sujeto delincuente por telenoticiero

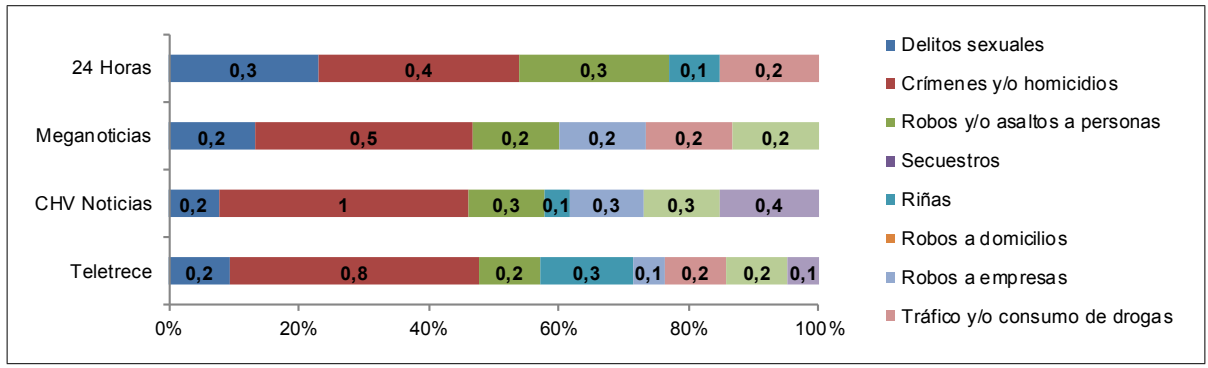

El segundo gran subtema presente ya se distribuye de modos singulares: para Teletrece tendrán mayor importancia el ítem riñas, luego vendrán los delitos sexuales, las incivilidades y el tráfico y/o consumo de drogas, todos con un 0,2 de casos. Una presencia marginal tendrán los subtemas secuestros y sistema judicial y/o penal.

Para 24 Horas, inmediatamente después de los crímenes y homicidios, nos encontramos con los delitos sexuales: 0,3 noticias por día; asimismo los robos y/o asaltos a persona, con idéntico número. Sorpresivamente aparece como tercera tendencia ( 0,2 noticias promedio) la cobertura a los hechos relacionados con tráfico y/o consumo de drogas, para terminar con una pequeña existencia del ítem riñas, de un 0,1 noticias al día.

Distribuidas de manera pareja, las noticias sobre sujeto delincuente en Meganoticias presentan un promedio de 0,2 noticias por día tanto para los casos de

12 La medida en este caso está dada por el promedio de notas cuyo exponente es, al igual que cuando no referimos a la desagregación temática, el valor constante para los tres ejes de análisis (28). De tal forma el número 1 representa un promedio de una nota en relación a dicho total, al mismo tiempo que 0,8 representa la presencia de 1 /fracción de noticia promedio de este subtema. 
delitos sexuales, robos y/o asaltos a las personas, tráfico y/o consumo de drogas e incivilidades.

Con la misma presencia encontramos un ítem muy poco presente en los otros noticiarios: los robos a empresas. Sólo Chilevisión Noticias pondrá un interés de cobertura en este ítem, con 0,3 de notas promedio.

Ahora bien, si lo miramos desde la perspectiva de los períodos muestrales, llegamos a la conclusión que nuevamente predomina el tema de los crímenes y/o homicidios en las cuatro semanas testeadas. En enero y marzo, el número de notas promedio fue de 0,8 por cada día. En cambio, para febrero sólo hubo un 0,5 de nota dedicada al ítem; y un 0,6 para la semana de abril.

GRÁFICO 17

Cobertura promedio de temas/hechos noticiosos que aluden al sujeto delincuente por semana

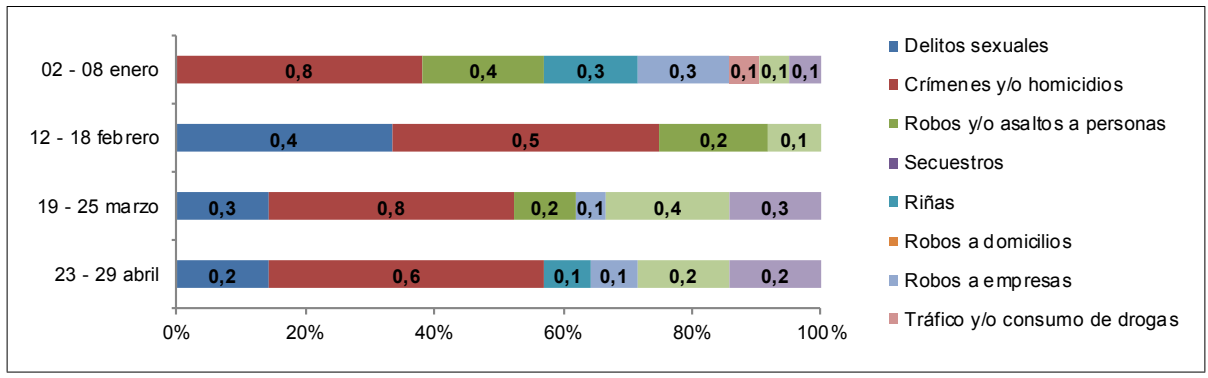

En segundo lugar, hubo un comportamiento irregular de dos variables. Mientras los delitos sexuales parecen una constante durante los meses de febrero, marzo y abril con $0,4,0,3$ y 0,2 respectivamente, la variable no aparece durante el mes de enero.

Un caso similar ocurre con el ítem robos y/o asaltos a personas. Mientras enero nos entrega 0,4 noticias por día, febrero y marzo nos proporcionan 0,2 noticias promedio. Sin embargo, la variable desaparece en abril, siendo reemplazada por otros hechos de interés.

Los robos a empresas también son una variable de cometido irregular durante el período de observación. En enero aparece con 0,3 notas promedio, para desaparecer en febrero, y renacer en marzo y abril, con 0,1 notas. Las riñas, por su parte, sólo aparecen en enero con 0,3 noticias; $y$ en abril con 0,1 noticias promedio por día.

La presencia se hace más constante para la variable incivilidades. En enero y febrero se presentó con 0,1 noticias, mientras aumenta a 0,4 y 0,2 durante los meses de marzo y abril. Algo similar sucede con las apariciones informaciones referidas al sistema judicial y/o penal. En enero apenas se asoma, con 0,1 noticias promedio por día. Desaparece durante febrero y se visibiliza nuevamente en marzo y abril: 0,3 y 0,2 notas, respectivamente. 
Finalmente, analizando la desagregación subtemática de los hechos noticiosos referidos al sujeto delincuente en función de la progresión semanal promedio, algunas cosas se mantienen y otras cambian: lo más evidente sigue siendo la presencia hegemónica de las informaciones que contienen elementos de crímenes y/o homicidios. En términos proporcionales, en los días martes ( 0,9 notas) y sábado (0,8 notas) es donde más se deja sentir el grado de cobertura. El resto de los días, por su parte, se mueven entre las 0,5 y 0,6 informaciones promedio.

\section{GRÁFICO 18}

Cobertura promedio de temas/hechos noticiosos que aluden al sujeto delincuente por semana

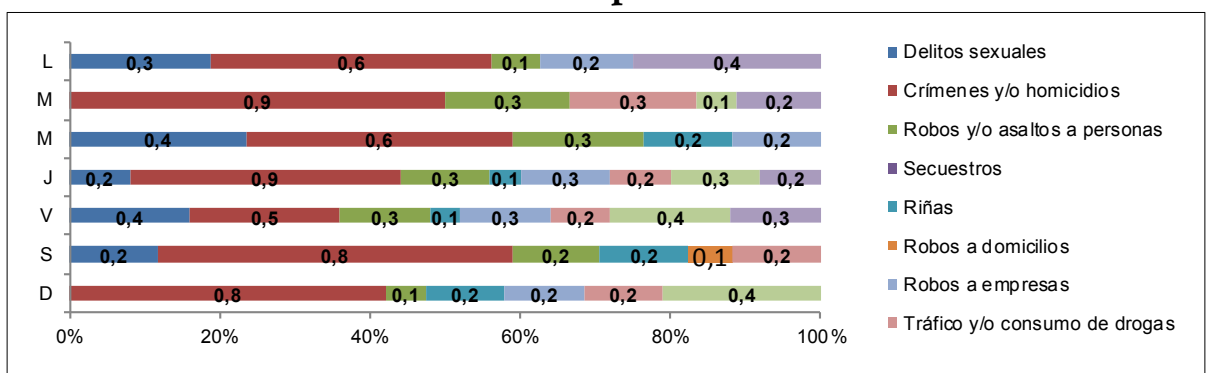

Ahora bien, es necesario llamar la atención sobre un punto que no había aparecido antes: si bien la cantidad promedio de notas de los días viernes sigue siendo alta en relación a las demás categorías de la subagregación, proporcionalmente hablando, la hegemonía decrece ostensiblemente para este tipo de noticias pertenecientes a la acción del sujeto delincuente. Esto se explica por el mayor grado de apertura demostrado en el promedio para tales días hacia más subtemas. Pues, como sigue, las informaciones referidas a delitos sexuales $(0,4)$, robos y/o asaltos a personas $(0,3)$, robos a empresas $(0,3)$, incivilidades $(0,4)$ y sistema judicial y/o penal $(0,3)$, representan en su conjunto una sumatoria capaz de restarle protagonismo a aquel subgénero que ya podemos asegurar como protagónico a estas alturas de nuestro análisis.

Otro detalle no avistado en virtud a los dos ejes anteriores aparece con los días martes: curiosamente, no aparecen informaciones referidas a delitos sexuales; lo mismo ocurre los días domingo. El resto de los días de la semana, en cambio, experimenta coberturas que la sitúan, en promedio, entre las 0,2 (jueves) y 0,4 noticias (miércoles), simultáneamente los dos días en los cuales la cobertura proporcional de delitos sexuales es mayor y menor en relación a los demás subtemas de la selección, respectivamente. Mientras tanto, las noticias relacionadas a tráfico y/o consumo de drogas, sistema judicial y penal, incivilidades, riñas y robos a empresas, salvo excepciones (sistema judicial los lunes, con 0,4 de promedio; drogas, con 0,3 los 
martes; e incivilidades, con 0,4 los sábados), aparecen asumiendo un perfil de relativa estabilidad, tal como quedó deducido de los análisis a partir de los ejes del telediario y de los períodos de muestra.

\section{g. Presencia de tiempo promedio (segundos) en los hechos noticiosos en los cuales se alude al sujeto delincuente ${ }^{13}$}

Cuando ahora observamos el promedio de tiempo que se destina a la cobertura del sujeto delincuente según el telediario en cuestión, parecen reordenarse las grandes tendencias de cobertura. Lo primero que cabe señalar es que sigue siendo predominante, en los cuatro noticiarios, el tema de los crímenes y/o homicidios, excepto un solo caso: 24 Horas. En su cobertura tiempo encontramos el surgimiento de la variable tráfico y/o consumo de drogas como la primera, seguida, eso sí, de los crímenes y/o homicidios. Los delitos sexuales tendrán un tercer lugar, seguidos de robos y/o asaltos. Luego serán protagonistas las incivilidades, las riñas y el robo a empresas.

\section{GRÁFICO 19}

Presencia de tiempo promedio (segundos) en los hechos noticiosos en los cuales se alude al sujeto delincuente según telenoticiario

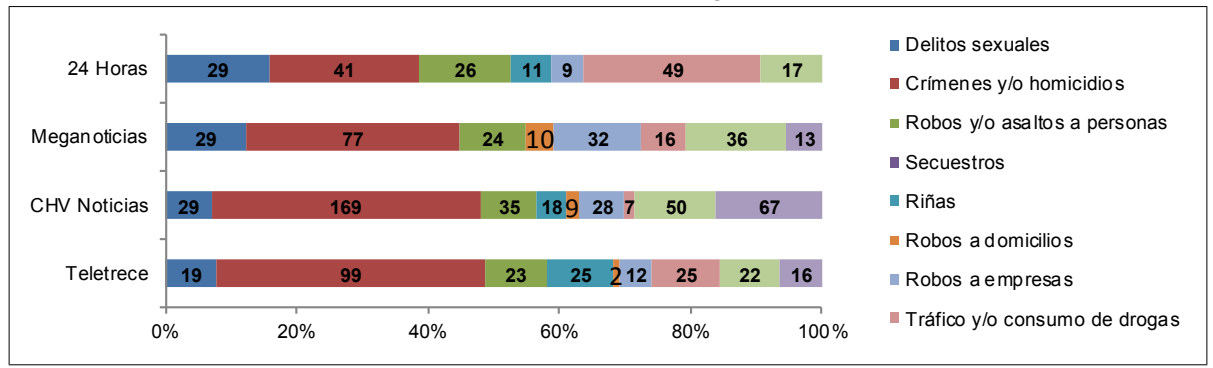

Para los tres casos restantes las variables se distribuyen de manera similar. En Meganoticias, por ejemplo, el segundo lugar en tiempo de cobertura lo ocuparán las incivilidades con 36 segundos de promedio, los robos a empresas con 32, y los delitos sexuales con 29. En porcentajes menores nos encontramos con los asaltos a personas,

13 Cuando las cifras promedio alcanzan valores por debajo de los 30 segundos, ello se debe, una vez más, a la división en base al total estándar (28). Al respecto, en más de algún caso una presencia temporal mínima alude a la ubicación de una noticia en particular al interior de la sección "reportajes", presentes en todas las emisiones analizadas aquí. De acuerdo a las condiciones de tal espacio, en los hechos esto significa una noticia de amplia duración, pero de ningún modo presente regularmente de nuestros tres ejes de análisis. Procedemos así en virtud de nuestro delineamiento hipotético. 
tráfico y/o consumo de drogas, sistema judicial y/o penal y robos a domicilios, con 24, 16, 13 y 10 segundos, respectivamente.

En Chilevisión Noticias observamos que la enorme cobertura que se da a los crímenes y homicidios, a pesar de ser muy alta, no impide la aparición de otras variables. Si bien esta arroja 2 minutos y 49 segundos de tiempo promedio, también habrá una poderosa presencia de los temas referidos al sistema judicial y/o penal (de 1 minuto y 7 segundos), seguido de 50 segundos dedicados a las incivilidades, luego los robos y/o asaltos a personas con 35, y los delitos sexuales con 29. También existe presencia de las variables: robos a empresas, delitos sexuales, robos a domicilios, y tráfico y/o consumo de drogas, con 28, 18, 9 y 7 segundos, según el orden indicado.

Una gran presencia de los crímenes y/o homicidios también se rescata en Teletrece, con 1 minuto y 39 segundos promedio. Las riñas y los delitos sexuales se presentan con una misma recurrencia de 25 segundos. También hay una similar de los temas de robos y/o asaltos a personas, de las incivilidades y del sistema judicial y/o penal. Muy por debajo, mientras tanto, damos con los robos a empresas y los robos a domicilios, con apenas 12 y 2 segundos promedio.

GRÁFICO 20

Presencia de tiempo promedio (segundos) en los hechos noticiosos en los cuales se alude al sujeto delincuente según semana

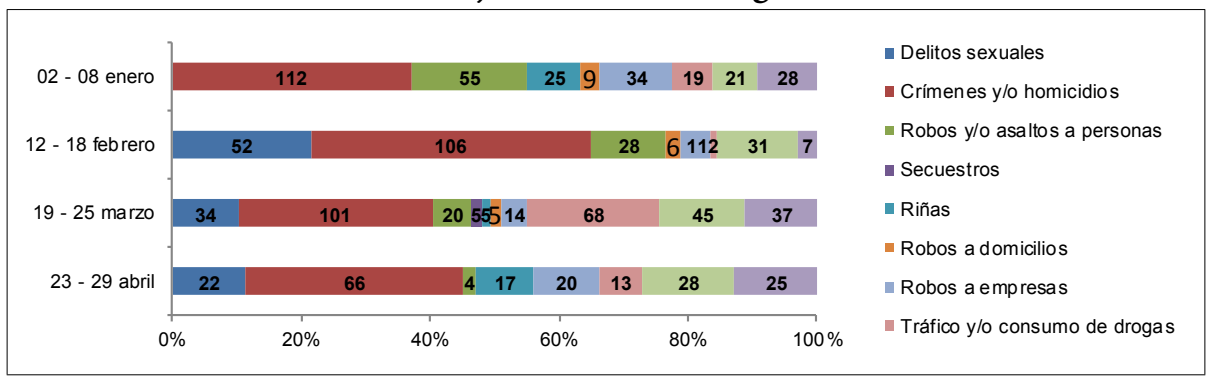

En cambio, el gráfico según los períodos muestrales muestra una distribución bastante más dispersa. Por de pronto, sigue siendo muy importante el tema de los crímenes y homicidios en las cuatro semanas testeadas de enero, febrero, marzo y abril. Sin embargo, hay un decaimiento de la variable hacia abril, bajando de 1 minuto con 40 segundos hacia sólo 1 minutos con 6 segundos. La segunda variable más importante en tiempo para enero serán los robos y/o asaltos a personas, con 55 segundos. Luego vendrán 34 segundos promedio de robos a empresas, noticias del sistema judicial y/o penal, las riñas, las incivilidades y el tráfico y/o consumo de drogas. Marginalmente, con sólo 9 segundos, se presenta la variable robos a domicilios.

Para febrero la segunda variable más importante son los delitos sexuales, con un promedio de 52 segundos. Enseguida se ubican cercanas las incivilidades y los robos 
y/o asaltos a personas. Después habrá que considerar la existencia muy marginal de los robos a empresas, las notas del sistema judicial y/o penal, los robos a domicilios, y el tráfico y/o consumo de drogas: 11, 7, 6 y 2 segundos, sucesivamente.

En marzo, la distribución cambia poniendo como segunda variable más persistente a las noticias sobre tráfico y/o consumo de drogas, con 1 minuto 8 segundos. Luego será el turno de las incivilidades (45 segundos); sistema judicial y/o penal (37 segundos), los delitos sexuales ( 34 segundos), y los robos y/o asaltos a personas (20 segundos). También habrá una presencia pequeña (14 segundos) sobre noticias de robos a empresas, y todavía menor presencia de secuestros, riñas y robos a domicilios ( 5 segundos para cada una).

Por último, abril se muestra como un mes con presencias similares de los ítemes incivilidades, sistema judicial y/o penal, delitos sexuales y robos a empresas, todos fluctuando entre los 28 y 20 segundos. Una baja presencia acusan las riñas y el tráfico y/o consumo de drogas (para el caso de este último indicador, se muestra un declive considerable respecto de marzo, con apenas 13 segundos). Sorprende la baja dedicación para los temas de robos y/o asaltos a personas (4 segundos).

Finalmente, en lo relativo a la evolución semanal, las proporciones temporales de cada subtema nos devuelven a ciertas observaciones anteriores, sin perjuicio de lo cual se manifiestan novedades: lo más significativo es, a simple vista, la ausencia de informaciones referidas a delitos sexuales durante los días martes y domingo. Sobre el mismo índice, la cifra promedio correspondiente a los días miércoles ( 1 minuto con 9 segundos) representa una proporción importante en relación a los demás temas y hechos noticiosos vinculados al sujeto delincuente, que alcanza al 25\% del total. Mientras tanto, los 41 segundos promedio de los días lunes implican, en la práctica, una presencia proporcional mucho mayor a los 39 segundos promedio de los días viernes. Esto se explica por una fórmula que designa una mayor amplitud y duración en los ítemes noticiosos durante la serie de este último.

\section{GRÁFICO 21}

Presencia de tiempo promedio (segundos) en los hechos noticiosos en los cuales se alude al sujeto delincuente según día de la semana

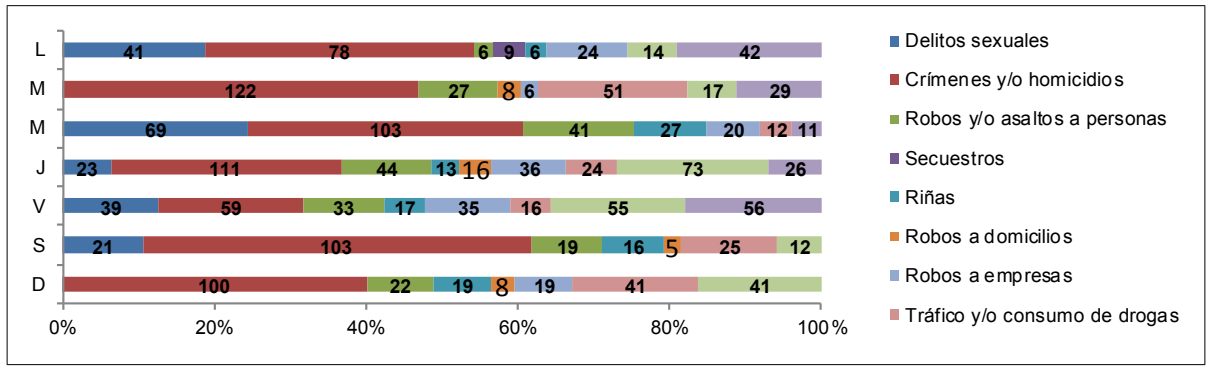


Mirando la presencia temporal promedio del tópico crímenes y/o homicidios, las cifras se comportan irregularmente: de 1 minuto con 18 segundos, asociado a la serie de días lunes, se salta hasta los 2 minutos y 2 segundos promedio de los días martes; los valores, a partir de allí, y hasta el jueves, se presentarán estables ( 1 minuto con 43 segundos los miércoles; 1 minuto con 51 segundos los miércoles). No obstante, una importante baja experimenta este subagregado durante los días viernes, en los que en promedio retrocede hasta los 59 segundos.

Tal como lo señalásemos con las noticias relacionadas a delitos sexuales, este descenso conlleva una indesmentible contraparte en términos proporcionales, si bien todavía significativa en tanto constituye la primera mayoría. En definitiva, según se visualiza, podemos llegados a este punto indicar que la serie de días viernes es aquella que exhibe el mayor grado de ecuanimidad temporal. Al contrario, los días miércoles ostentan clara preponderancia específicamente -y según se deriva de las observaciones a partir de los ejes de análisis anteriores- por parte de las noticias sobre delitos sexuales, crímenes y/o homicidios y robos y/o asaltos a personas.

Volviendo a nuestro balance, junto a los dos índices antes tomados, el tercero y último que demuestra una presencia temporal constante en la extensión completa de las unidades de medida es el que designa a los robos y/o asaltos a personas. Ahora bien, su trayectoria a partir de la evolución semanal es ascendente: de los escuálidos 6 segundos promedio observables durante los días lunes, el resto de la semana luce períodos promedio que oscilan entre los 19 y 41 segundos; estos tiempos, en todo caso, no establecen grandes diferencias proporcionales respecto de las disponibilidades generadas en cada grupo de días.

Sumado a lo anterior, un detalle llama la atención. Tiene que ver con las noticias relacionadas a tráfico y/o consumo de drogas: si bien su presencia es constante -salvo los días lunes-, desde el punto de vista proporcional demuestra notables variaciones: mientras los 51 (martes), 41 (domingo) y 25 segundos (sábado) promedio observables constituyen, en su conjunto, casi el 20\% del total de la distribución, los 24 segundos promedio de los jueves, sólo 1 menos, se quedan por debajo del 10\% de la apertura subtemática. Viernes y miércoles, por su parte, contemplan promedios de 16 y 12 segundos respectivamente.

Otro tanto ocurre con las noticias relacionadas con robos a empresas. Aquí, los 24 segundos promedio de los días lunes se ven sucedidos por sólo 6 segundos de los martes. Miércoles, jueves y viernes el valor repunta y alcanza, en ese orden, a los 20, 36 y 35 segundos promedio. Correspondiente a la cantidad de noticias por cada subtema desde la sucesión semanal, los días sábado no hay presencia de tiempo; los domingos, en suma, reaparece el índice, con 19 segundos promedio. Observable de este desarrollo, a excepción del menguado $2 \%$ asociado a la serie de días martes, la visibilidad proporcional de las noticias referidas a este ítem representa, en su conjunto, una porción cercana al $15 \%$ del total. 
El resto de los indicadores en cuestión -riñas, robos a domicilios e incivilidadesmuestra comportamientos similares a los dos últimos casos comentados; vale decir, presencias proporcionalmente dispares, además de ciertas irregularidades respecto a la constancia de su presencia en términos del abanico de temas relativos al sujeto delincuente disponible. A su lado, el "elemento extraño" cuya detección ya hemos explicado apoyándonos en la fórmula estadística utilizada en general para este análisis ${ }^{14}$ : los 9 segundos promedio, sólo durante los días lunes, de las noticias referidas a secuestros.

\section{Comentarios finales}

A partir de la primera forma de agregación y análisis utilizada, canal/emisor, nos damos cuenta en primer lugar que los tiempos relativos de informaciones y publicidad son bastante estables y similares en los cuatro telediarios seleccionados. En orden de relevancia, quienes más tiempo dedicado a publicidad desembozaron en comparación con el tiempo que dedicaban a la noticia fueron Meganoticias, Teletrece, 24 Horas y Chilevisión Noticias.

Quien mayor cantidad de noticias exhibió en promedio en los diferentes períodos testeados, y por lo tanto más cobertura expresó hacia los temas y hechos de la actualidad noticiosa, fue Teletrece. Luego Chilevisión Noticias, y detrás de ellos 24 Horas. Meganoticias es el telediario con menor acervo. Aunque si se miran las duraciones promedio de este exponente en relación a sus pares, la única explicación posible son sus treinta minutos menos entre lunes y viernes. En los otros casos, a su vez, las diferencias se podrían explicar por la presencia de notas pequeñas que corresponden a los segmentos nacional e internacional, a menudo a manera de "bloques" que reúnen en un solo tape varias informaciones.

Los temas que más cubren los canales se relacionan a las noticias que tienen que ver con cuestiones de sociedad y cultura. En segundo orden de prioridad aparecen los deportes. La cuestión se hace menos clara caso a caso. Teletrece tiene en tercer lugar a la política y en cuarto a lo que a lo largo de este informe hemos considerado como "sujeto delincuente", al igual que 24 Horas. Para los otros dos canales, Meganoticias y Chilevisión, la tercera tendencia es, sin lugar a dudas, nuestro tópico indagado.

Convirtiendo los segundos en porcentajes, la mediación de la variable tiempo ratifica el lugar predominante del sujeto delincuente en todos los noticiarios. Para los cuatro casos el tema es un pilar de su cobertura: 5,8\% de 24 Horas; 8,2 \% de Teletrece;

14 Véase nota anterior. 
12,6\% de Meganoticias; y 14,5\% de Chilevisión Noticias. Esta tendencia se mantiene también en el número de notas conducidas por cada uno.

Para ver si ambas medidas, tiempo y número de notas, mantenían o no un estado de correspondencia se comparó su comportamiento para cada caso. Si bien se mantiene el orden dado recién, queda en evidencia que pese a que la cantidad promedio de informaciones en ciertas comparativas es la misma, no ocurre de igual manera con los tiempos promediados.

En parte, una explicación de esta situación se puede argumentar en la operación misma del promediar, cuya varianza obliga a aproximar los cocientes al 0,5. Aún considerando estapequeña distorsión, consideramos quelos 17 segundos de diferencia del ejemplo propuesto alcanzan a contener, cuanto mucho, una pequeña nota informativa, y en este sentido sólo así se le puede considerar relevante. Clasificando las noticias encontradas según el tipo de delito que designan, encontramos claramente el predominio en todos los canales del subtema que llamamos genéricamente crímenes y/o homicidios. Así mismo, entendemos que la cobertura que hacen los canales es compleja, puesto que variables que ni quiera tiene una presencia relevante en algunos (o simplemente desaparecen) en otros canales ocupan un lugar considerable.

El segundo lugar de mayor cobertura se debe analizar de manera específica canal a canal. En el caso de Teletrece surge sorpresivamente el subtema riñas, cuestión que no aparece en los otros casos estudiados. En 24 Horas emergen los delitos sexuales, mientras la distribución más equitativa de las segundas tendencias se da en Meganoticias. Para Chilevisión, la segunda noticia de mayor relevancia son los temas que se relacionan con el sistema judicial y/o penal. Esta cuestión no es menor, en el entendido de que el canal cumple una función relevante de poner en pantalla un sistema de hacer justicia relativamente reciente y aún a prueba en el contexto nacional.

$\mathrm{Si}$ bien es cierto que los canales exhiben una cobertura particular de cada tema, encontramos que los dos subtemas de principal cobertura para cada canal suman cerca del $50 \%$ de las noticias sobre sujeto delincuente. Así, los dos primeros subtemas de Teletrece suman 52,4\%, 53,8\% los de Chilevisión Noticias, 46,7\% los de Meganoticias, y 53,8\% los de 24 Horas. Estos porcentajes muestran, en síntesis, la distribución para nada proporcional de las variables llamadas subtemas en las noticias de los canales.

Trasladándonos hacia la variable tiempo, medida en segundos, el análisis según telediario nos expresa una tendencia muy similar a la mostrada con el número de notas según subtemas. Lo primero que cabe señalar es que sigue siendo predominante, en los cuatro noticiarios, el tema de los crímenes y/o homicidios. Sin embargo, se produce una excepción: 24 Horas. Aparecerá ahora, de manera predominante, el tema del tráfico y/o consumo de drogas como la categoría promedio con más tiempo dedicado.

Si bien aparecen nuevos temas como robos a personas e incivilidades, las 
tendencias siguen siendo las mismas. Realizando el mismo ejercicio de agrupación de los dos subtemas más presentes en segundos promedio, también nos damos cuenta que la suma da cerca del $50 \%$ de cobertura sobre el sujeto delincuente. Para este caso, Teletrece suma con sus dos variables un 51\%, Chilevisión Noticias un $57,3 \%$, Meganoticias un 47,7\% y 24 Horas un 49,5\%. Estos porcentajes dan cuenta, nuevamente, de que existen algunos temas predilectos para los noticiarios en donde se alude a la figura de sujetos que realizan actos susceptibles de ser calificados como delictivos.

Una vez observada la dimensión canal/emisor, podemos revisar la presencia ausencia según el período de muestra. De esta forma, la distribución de la publicidad se comporta de una manera incremental a medida que avanzó la pesquisa: febrero aparece como el mes con menos publicidad en comparación con las noticias; luego marzo, que exhibe un poco más, para llegar al máximo en abril. Si ponemos en perspectiva estas afirmaciones tenemos que, al comparar el porcentaje de tiempo que ocupa cada mes en publicidad - con respecto al tiempo total del noticiario- tenemos a abril con 18,4\%; marzo con 17,3\%; enero con 15,3\%; y febrero con un $14,4 \%$.

Estos resultados anuncian una conclusión preliminar sobre el período de estudio: los noticiarios siguen una lógica que se manifiesta dinámica según la época del año. En esta razón encontramos gran parte de algunas distorsiones posibles de ser encontradas en la muestra elegida. Respecto al número de notas, tenemos que la semana con más noticias correspondió a febrero, con 19 noticias promedio. Luego se ubican enero y abril con un índice de 18 notas por día. Y en último lugar se encontraría la semana de marzo, con 16 notas.

Refiriéndonos ahora a cómo se distribuyen estas, observamos que continúa habiendo una tendencia. Sigue siendo predominante la presencia de las noticias de sociedad y/o cultura en todas las semanas testeadas cada mes. En seguida las siguen de cerca las noticias sobre los temas del área deportiva, para en un tercer lugar aparecer el sujeto delincuente. Sin embargo, comparte este lugar con la cobertura que se da del tema política, ubicado en un status similar.

Dentro de este contexto, el mes donde más se hace presente la variable cultura y/o sociedad es febrero, y donde menos aparece es en marzo. Esto tendría que ver con la cobertura durante los meses de verano de un gran número de noticias sobre turismo y tendencias en la sociedad, cuestión que disminuye cuando entramos en los primeros meses del año. A esto podríamos denominarlo "efecto estacional". Pasando estos meses y su efecto, el interés se redirige hacia las áreas de cobertura tradicional: política, economía, seguridad, deportes.

Para nuestro objeto de estudio, la cuestión del tiempo también muestra que hay pequeñas diferencias en los tiempos promedio que dedica cada semana. Marzo será el mes de mayor presencia temporal, seguido de enero, febrero y abril. En términos porcentuales, la variable se comportó así: 13,1\% en marzo; 11,1 en enero; 8,7\% en 
febrero; y 6,5\% en abril. Esta cuestión, vale considerarlo, se podría ver distorsionada por la cobertura extensiva e intensiva que realizaron los noticiarios de dos temas: el terremoto en Aysén la semana correspondiente a abril, y la instalación del sistema de transporte público Transantiago en febrero y marzo. Estos dos hechos ocuparon gran parte del noticiario durante esos períodos, pudiendo explicar la menor presencia del tema estudiado.

Nuevamente cruzamos el número de notas con el tiempo dedicado. Extrajimos de ese ejercicio una distensión parecida a la registrada en el análisis por telediarios. Sin embargo, las diferencias entre los períodos muestrales registrados son de mayor envergadura, llegando a cerca de 1 minuto para casos con el mismo número de notas. Esto podría responder a las razones ya expuestas para el análisis por canales, además de implicar las dinámicas "estacionales" de cobertura.

Analizando las noticias privilegiadas en cada semana-mes, nos encontramos que en enero desaparecen las violaciones, surgiendo fuertemente el subtema tráfico y/o consumo de drogas, relevante sólo para este período. Sorpresivamente, surgen para marzo y abril el complejo tópico de las incivilidades, y las riñas para enero-febrero. El sistema judicial desaparece en febrero para resurgir sólo en los meses productivos. En términos porcentuales, agregando las dos variables más significativas para cada mes tenemos que abril suma un $57,1 \%$; marzo igualmente un $57,1 \%$; febrero un asombroso $75 \%$; y enero, otra vez, un promedio de $57,1 \%$.

Esto reconfirma la idea de que existen dos problemas predominantes en cada caso estudiado, ya no sólo por canales, sino también por período. Si lo primero se podía explicar quizá por razones editoriales solamente, en el segundo caso debiéramos hablar de algo así como el posicionamiento temporal de temas de alto interés, que dependen de las propias lógicas de los temas de cobertura y de otras variables aún no identificadas. De todas formas, el tema no parece estar para nada resuelto.

También se muestra bastante dispersa la variable del segundo subtema más cubierto si la miramos en torno a la variable tiempo promedio medido en segundos. En primer lugar, este análisis muestra que la primera mayoría promedio, crímenes y/o homicidios, cae hacia la semana de abril, bajando de 1 minuto 40 segundos a sólo 1 minutos 6 segundos. Para la semana de enero suben los robos a personas. En febrero se incrementan los delitos sexuales y en marzo sube el tráfico y/o consumo de drogas. Las dos primeras inclinaciones para los períodos de estudio suman, en consecuencia: $55,1 \%$ en enero; $65,1 \%$ en febrero (nuevamente la concentración más aguda); 50,6\% en marzo; y 46,7\% en abril. Estos datos contradicen la lógica de aparición de los subtemas según los emisores. Ello implica que los períodos de muestra siguen una lógica propia, que en ningún caso se reduce sólo a las variables estudiadas en el caso de los canales.

Para finalizar, las conclusiones derivadas de un análisis en función de la evolución semanal promedio fortalecen los mismos comportamientos visualizados desde los 
ejes canal/emisor y período muestral: la relación entre publicidad e información durante el lapso total promedio del telediario no da señales de grandes diferencias. Asimismo en lo relativo al total de noticias promedio, índice del cual aparece una oscilación entrelas 17 ylas 20 noticias. Una primera observación interesante aparece al momento de tomar la distribución temática promedio y el número de informaciones al interior de cada subdivisión: lo que a lo largo de la semana se manifiesta como un indiscutible predominio sustentado entre las informaciones referidas a hechos y temas de sociedad y/o cultura y deportes -y el tema sujeto delincuente secundando con cifras que fluctúan indistintamente entre las 2 y 3 notas promedio, luego política, e internacional y economía- hacia los días domingo la muestra se presenta algo más equilibrada en la repartición. Esto, probablemente, se deba a dos motivos, uno más directo que el otro: por un lado la mediación de los habituales resúmenes deportivos de fin de semana; y por lo demás, la misma composición del telediario durante este día, especialmente configurado para pasar revista a los sucesos más destacados de la semana en curso.

Ahora, nuevos antecedentes surgen cuando nos planteamos respecto de la presencia temporal del conjunto de informaciones relativas al sujeto delincuente en relación a la sumatoria general del espacio televisivo: de lunes a jueves la duración promedio de este tópico asciende progresivamente, al tiempo que restándole presencia a todos los demás. Viernes y sábado los valores regresan a los originales a principio de semana, para darle un último gran espacio -y por las razones que hemos indicado- a la serie de días domingo.

Todo parece apuntar, visto así, que la temática amplia que hemos perfilado como la constelación del sujeto delincuente se ofrece como un polo de desarrollo que va adquiriendo protagonismo a medida que la semana laboral avanza conforme a sus evoluciones normales.

Por supuesto, bien vale tener en consideración que en esta agrupación se reúnen tanto los emisores/canales como los períodos, los cuales ya hemos descrito en sus particularidades; ante ese hecho, el que se observe un comportamiento estable es indicativo de que se trata del componente de ya una tercera lógica independiente.

Para finalizar, si en lo tocante a la distribución tanto en número como en el tiempo de los temas y hechos que constituyen la dimensión asociada al sujeto delincuente se captan ciertas tendencias significativas, no es algo que podamos definir desde el punto de vista cuantitativo, en tanto estas tendencias - que son mucho más difusas que las expresadas según los ejes de análisis antes revisados- no hablan tanto de estrategias por situar tal o cual tipo de informaciones en tal o cual día. Sino más bien, según creemos, es mucho más un corolario no relevante al interior de lo expresado en la bien sólida panorámica general que con este informe hemos intentado proyectar. 


\section{Capítulo 5}

\section{LA REPRESENTACIÓN DEL SUJETO DELINCUENTE}

Una primera constatación en relación con la forma en que el sujeto delincuente es representado en los telenoticiarios es que dicha representación no es única sino diversa, es decir, no aparece un único sujeto delincuente sino varios tipos de sujeto con diversas motivaciones, características, modos de actuar y de presentarse. Sin embargo, esto no significa que todos ellos tengan la misma importancia dentro de la representación televisiva de la delincuencia ni que exista una total discontinuidad entre las distintas representaciones presentadas al público, se trata más bien de una dispersión organizada que, como veremos, tiene un cierto sustrato común.

A continuación, nos referiremos a los distintos tipos de delincuente que aparecieron representados durante el período considerado para, a continuación, señalar algunos puntos de continuidad entre todos ellos.

\section{El Celotípico o Enajenado Mental Transitorio}

Uno de los delitos a los que se les da más cobertura durante el período analizado es a los "crímenes u homicidios" y, dentro de ellos, a los llamados "crímenes pasionales", especialmente los femicidios. En estos casos el denominador común de los relatos es la búsqueda de posibles episodios de infidelidad como móvil de los crímenes; los que, de esta forma, son presentados siempre como el resultado de arranques pasionales en los que la razón se ve nublada por los celos, desencadenando una reacción violenta que, en la mayoría de las ocasiones, es seguida de la toma de conciencia de la gravedad de los hechos y el arrepentimiento.

La pérdida del control de los propios impulsos destructivos es la que explica el aparente desajuste entre la personalidad basal del agresor y la intensidad de la violencia alcanzada durante el episodio; en este sentido, abundan los testimonios que señalan que el imputado aparecía como una persona tranquila o, incluso, introvertida. Sin embargo, también se destacan aquellos antecedentes que dan cuenta de un historial de violencia al interior de la pareja, los que son mostrados como un proceso de escalada que antecede al estallido final y lo hacen finalmente previsible.

Un caso ejemplar en este sentido lo representa la noticia emitida el día 20 de marzo por Chilevisión Noticias y que daba cuenta de un hombre que había asesinado a su esposa de tres disparos en plena vía pública. Dada la forma en que es presentada la noticia, los hechos aparecen incomprensibles a primera vista, no por el homicidio en sí mismo ni por el ensañamiento (los tres disparos fueron en el rostro de la mujer) 
sino por el hecho que el imputado sacó a su ex esposa desde el domicilio en donde ella residía y la arrastró cerca de tres cuadras para asesinarla en la vereda. Esta conducta puede ser integrada coherentemente en el relato sólo hacia el final de la nota, cuando la fiscal a cargo del caso explica que la vivienda frente a la cual la mujer fue asesinada pertenecía a un hombre con el cual, presuntamente, ella habría mantenido una relación amorosa.

Un caso similar es el de la noticia emitida el día 25 de marzo por el mismo noticiero y que da cuenta de la detención de un hombre que asesinó de tres puñaladas a su padrastro. En este caso, quien presenta la hipótesis de los celos es el propio reportero quien se refiere a "celos de hijo" por la relación que la madre mantenía con este hombre. Dicha hipótesis aparece respaldad por el testimonio de algunos vecinos que, para este efecto, operan como informantes clave. Luego, el propio imputado reconoce su crimen y lo atribuye a un impulso que fue incapaz de controlar, mediante expresiones como "no sé qué me pasó" o "no me acuerdo de nada".

En ambos casos y en otros que fueron presentados durante el período de análisis, los involucrados en los hechos son gente de extracción social humilde, habitualmente provenientes de poblaciones de la zona sur de Santiago y, en muchos casos, los imputados son presentados como personas cuya salud mental se encontraba en una fase de deterioro (con procesos depresivos en curso generalmente asociados a algún tipo de toxicomanía, típicamente alcoholismo), aunque eso no siempre fuera visible para las personas de su entorno. Durante todo el período analizado, no se presentaron casos donde los involucrados tuviesen una extracción social más acomodada, de modo que, representacionalmente, este problema aparece circunscrito a los sectores menos favorecidos y, desde ese punto de vista, más vulnerables.

\section{El Loco o Demente}

Mientras en el caso anterior el acto irracional obedece a un episodio momentáneo de pérdida de la racionalidad, en el caso del loco o demente esta es una condición permanente, de modo tal que no se encuentra en situación de responder por su propia conducta, siendo más bien objeto de cuidados médicos que de intervención jurídico penal.

Durante el período analizado sólo apareció una noticia de este tipo, emitida el día 17 de febrero y en ella se mostraban las condiciones de vida de un joven esquizofrénico que, algunos meses antes, había apuñalado a una de sus vecinas producto de lo cual fue arrestadoy, luego de confirmar su condición mental, trasladado al hospital psiquiátrico desde donde huyó para volver a su domicilio. En el relato, luego de recordar detalladamente la agresión sufrida por la mujer y de entrevistarla nuevamente, resaltando la sensación de temor e inseguridad que la agobiaba al ver a 
su agresor en la calle, se presenta la situación de abandono en que vive el joven quien, presa de constantes alucinaciones por no recibir tratamiento para su enfermedad, es incapaz de cuidar de sí mismo. Se trata, por tanto, de un sujeto que no sólo representa un peligro para la sociedad sino también, y ante todo, para sí mismo.

\section{El Monstruo}

Un tipo de sujeto delictivo emparentado con los anteriores pero que en muchos sentidos desborda los límites de lo procesable desde las coordenadas del sentido común, dado lo extremo e incomprensible de su comportamiento, es el monstruo. En cierto sentido, el monstruo viene a representar una mezcla entre los dos tipos anteriores: por una parte, se muestra como una persona normal que es presa de ciertos impulsos irrefrenables; por otra, dada las características de esos mismos impulsos, es también un enfermo. En todo caso, el rasgo definitorio del monstruo es que mediante su comportamiento vulnera de un modo frontal algunos de los principios y/o tabúes más básicos de la sociedad, tales como el instinto materno o paterno o la protección de los niños, entre otros. Un ejemplo claro de esto lo representa la noticia emitida el día 13 de febrero, en la que se da cuenta de la solicitud de libertad bajo fianza presentada por un hombre que en diciembre del año 2005 agredió a su esposa y asesinó a su hija de 6 años lanzándola desde el séptimo piso de un edificio hacia la calle. Evidentemente, se trata de un comportamiento que aparece como extremo, injustificado e, incluso, contraintuitivo puesto que, desde el sentido común, se supone y espera que la primera reacción de un padre debe ser la de proteger a su hija y no exponerla a la muerte. La reacción del imputado resulta aún más incoherente cuando la periodista señala que actuó con sangre fría, esto es, no como producto de un arrebato episódico sino premeditadamente.

Un tipo diferente pero igualmente monstruoso lo representa el pedófilo. Se trata de un tipo de sujeto en apariencia normal pero que esconde la mayor desviación concebible que es atacar sexualmente a niños inocentes. Aunque el caso con más notoriedad pública aparecido durante el período corresponde al de Rafael Maureira (más conocido como Zacarach) la noticia emitida durante el período analizado se centraba principalmente en su fuga y en los esfuerzos realizados por la policía para capturarlo, por lo que los contenidos de esas notas no entregan demasiada información sobre cómo la prensa se representa a este tipo de sujetos.

Donde esto queda más claro es en la noticia emitida con fecha 25 de abril y ya mencionada anteriormente, sobre un ex suboficial de la Armada de Chile quien abusaba sexualmente de sus hijos, de un sobrino y del hijo de un amigo, a quienes amenazaba señalando que, si lo delataban, él se suicidaría. En este caso, el sujeto es capturado y conducido por la policía hacia los tribunales lo que da ocasión a los 
periodistas para interrogarlo: llama la atención que, en este caso, el interés de los periodistas se centre en despejar dos interrogantes: saber si está enfermo y saber si está arrepentido, es decir, el habla periodística intenta lograr que el sujeto busque la expiación. No se trata de un hecho menor, se intenta forzar al sujeto a que reconozca su desviación conductual, la rechace y, paralelamente, ensaye la única hipótesis que podría redimirlo y que es la de la pérdida del control sobre su conducta.

Ya sea porque violente física o sexualmente a sus víctimas, un denominador común del monstruo es que despliega su violencia contra quienes menos se pueden defender que son los niños. Lo aberrante de esta conducta es que no sólo daña físicamente sino, sobretodo, moral y emocionalmente a quienes menos se pueden defender, haciéndolos perder el único bien que no volverán a recuperar: la inocencia.

\section{El joven delincuente}

La imagen del joven delincuente representa el tópico más frecuente al que recurren los noticieros televisivos al momento de abordar la delincuencia común, entendida ésta especialmente para los casos de "robos y/o asaltos a personas" e "incivilidades". En estos casos se trata casi siempre de jóvenes de sexo masculino, pertenecientes a sectores populares de Santiago (típicamente la zona sur) que, por lo general, son mostrados actuando con gran violencia y decisión, la mayor parte de las veces en grupos de tres o cuatro personas, y casi siempre motivados por la adicción a las drogas o, simplemente, por la necesidad de sobrevivir.

Un claro ejemplo de lo anterior es la noticia emitida en la edición del día 9 de abril referida al asalto sufrido por una botillería del sector sur de la capital. En este caso, el relato es apoyado con imágenes obtenidas de la cámara de seguridad del local comercial en la que se observa a un grupo de tres jóvenes encapuchados, armados con pistolas, que irrumpen en el local y amenazan al cajero, luego de lo cual uno de ellos salta por sobre el mostrador y extrae el dinero desde la caja para, posteriormente, volver a apuntar al cajero con la pistola hasta que, finalmente, huyen del lugar.

Es posible relacionar la estructura de esta noticia con la de muchas otras, aparecidas en otros períodos, donde se muestran grupos de jóvenes asaltando todo tipo de establecimientos comerciales (farmacias, estaciones de servicio, locales de comida e incluso buses del transporte público), muchas veces a rostro descubierto y siempre utilizando algún tipo de armamento para intimidar a sus víctimas, ya sean armas blancas o de fuego.

Aunque habitualmente se trata de grupos reducidos que actúan dando pequeños golpes donde el elemento sorpresa es clave para el logro de sus objetivos, durante el período analizado se prestó especial atención a una forma diferente de asociatividad delictiva, más compleja tanto desde el punto de vista organizacional como del alcance de sus objetivos $y$, desde esta perspectiva, también más amenazante para el orden 
social: las pandillas. Si bien el tema de las pandillas no es completamente nuevo (hay quienes remontan su aparición a la década de los ' 50 y su estudio sistemático comienza ya en la década de los ' 80 ), sí resulta relativamente novedosa la vinculación directa que, en este caso, se hace con el tema de la delincuencia. Chilevisión, por ejemplo, nos presenta dos noticias que, a su vez, representan los dos polos en torno a los cuales se organizaría este fenómeno: en primer lugar, tenemos la noticia emitida en la edición del mismo 9 de abril y que bajo el titular "Guerra de pandillas en La Pintana” aborda el conflicto entre dos grupos de jóvenes de esta población, conocidos respectivamente como Los Guarenes y Los Philips. En este caso particular, la noticia trata sobre un joven que habría sido asesinado de dos disparos en la frente, luego de sostener una fuerte discusión mientras bebían juntos; el autor pertenecía a Los Philips mientras que la víctima era miembro de Los Guarenes. La nota incluye, entre otras, una declaración del fiscal especial designado para investigar a estas pandillas, en la que señala que la zona sur es el lugar donde se producen los delitos más violentos y considera la utilización de una infografía en la que se muestra lo que parece ser el organigrama de una de estas pandillas, con las fotografías de sus miembros mayores de edad (la de los menores aparece distorsionada). Esta noticia tuvo su continuación el día 26 de abril en donde, bajo el titular de "Dos violentas pandillas en el ojo del huracán”, se informó que Los Philips habían despedido a uno de sus miembros con disparos al aire, durante su funeral y donde, luego de escuchar el testimonio del asesino durante el Juicio Oral (quien acusa a la banda rival de tener armas y traficar drogas), se utilizan mapas para delimitar las zonas controladas por cada uno de los grupos en conflicto.

Como podemos observar, estaríamos delante de una verdadera subcultura del delitoque daría origen a agrupaciones juveniles organizadas como verdaderas "mafias" que buscarían controlar ciertos espacios territoriales para, desde ellos, proyectar una acción delictiva de mayor alcance (como sería la protección de traficantes o, directamente, el tráfico de drogas o de armas). El elemento fuertemente subcultural y simbólico que está a la base de este tipo de agrupaciones queda nítidamente expresado en la noticia emitida con fecha 26 de abril donde se da cuenta de la captura del asesino de dos hermanos, calificados por el noticiario como choros de una población (que fueron muertos por otro choro, por lo tanto, en su ley), destacándose que durante su funeral se habría desarrollado un extraño ritual en el marco del cual sus familiares y amigos rociaron pisco sobre las tumbas mientras compartían un pito de marihuana. Para reafirmar esta idea se hace una comparación con el fenómeno de las llamadas maras, propio de algunos países de Centroamérica como Guatemala o El Salvador ${ }^{15,} y$

15 Las "maras" son mafias compuestas por hombres y mujeres que fueron encarcelados en los Estados Unidos por la comisión de delitos violentos y que, una vez cumplida su condena, fueron devueltos a sus países de origen formando allí agrupaciones criminales extremadamente violentas que controlan barriadas completas en las que ni la policía puede hacer ingreso. 
se indica que, de no mediar alguna intervención, la situación podría agravarse.

En segundo término, tenemos la noticia emitida en la edición del día 25 de abril y en la que, bajo el titular de "Jóvenes neonazis se multiplican en la quinta región y provocan temor" se aborda el caso de un grupo de jóvenes, pertenecientes a un movimiento hitleriano, que habría atacado a otro grupo de jóvenes, pertenecientes a un movimiento okupa, que se encontraba viviendo en una casa abandonada.

Como puede apreciarse, aunque también se cometen delitos (como los delesiones o allanamiento de morada) en este caso el móvil es de tipo político-ideológico: se ataca a quienes piensan o viven de un modo diferente. No se trata, tampoco, de "mafias", como en el caso anterior, puesto que su modus operandi es más episódico que sistemático y su estructura, cuando existe, es mucho más elemental. Se trata más bien de grupos de vándalos, cuya acción, aunque destructiva, es más esporádica y tiene un alcance más limitado.

Podemos observar, entonces, dos polos: uno donde el propósito es propiamente delictivo y otro donde el propósito es político y el uso de la violencia y la comisión de delitos es más bien un medio. Lo que hace de ellos un continuo es el impacto que se atribuye a su actuar sobre el aumento de la inseguridad pública y la aparición del temor ciudadano; entre ellos se ubican otras expresiones como, por ejemplo, las llamadas barras bravas que son agrupaciones juveniles formadas alrededor del seguimiento de algún equipo de fútbol que presentan también episodios cercanos a lo delictivo.

\section{Sujeto delincuente: rasgos modales y rasgos basales}

Tal como hemos visto, más que un único sujeto delincuente, se nos muestran varios tipos de sujeto delincuente, cada uno de los cuales posee sus propias características, motivaciones, modus operandi, etc. Sin embargo, pese a esta dispersión, sí es posible observar ciertos rasgos modales que organizan esta representación, le dan continuidad y, a través de ello, contribuyen a mantener focalizada la atención del público sobre ciertos tópicos en particular.

Tal vez el rasgo más evidente sea que la mayoría de las noticias sobre delincuencia que se muestran en los noticieros televisivos aluden a hechos protagonizados por personas de sectores populares $\mathrm{y} / \mathrm{u}$ ocurridas en sectores populares, especialmente de Santiago. Dicho de un modo más directo: la mayoría de los delincuentes mostrados por la TV (independientemente de su subtipo) son pobres y la mayoría de los hechos delictivos ocurre en sectores populares.

En esa dirección, la temática sobre delincuencia y seguridad en los medios se articula con discursividades de larga historia en nuestro país y que dicen relación con las percepciones de las elites acerca de lo popular, entendido como otro radical, potencialmente amenazante. La industria cultural y los medios no han sido ajenos a ellas. 
En la actualidad, una de las formas en que se manifiesta la presencia de lo popular en el discurso televisivo está asociada a la idea de la amenaza y el temor. Pero, ya no se trata de la figura del roto alzado organizado en sindicatos o militante de partidos que, en tanto actor colectivo planteaba en su accionar la posibilidad que, a lo largo del siglo XX, se fue haciendo cada vez más cercana, de remover las bases del poder de los sectores dominantes. La figura actual es una amenaza directa a los bienes y las personas, pero sin ninguna perspectiva más allá del beneficio individual de los agresores. Las pantallas televisivas están permanentemente mostrando la amenaza de la delincuencia sobre los barrios acomodados. Lo popular como amenaza también aparece ligado al narcotráfico y a la existencia de pandillas y bandas que asolan barrios y poblaciones.

Desde la instalación del sistema democrático liberal representativo en 1990, fue emergiendo en el discurso mediático el tema de la delincuencia y la seguridad, planteado como uno de los problemas más centrales de la vida nacional. En este plano, pareciera constatarse un éxito de estas estrategias. Tanto los estudios de opinión como el accionar de los partidos políticos han ratificado, de manera bastante tautológica, esta suerte de profecía autocumplida. Así, el fantasma que recorre Chile es el del sujeto delincuencial construido por las discursividades mediáticas, como principal amenaza a la convivencia y el orden, que asume los rostros del asaltante de casas, del ladrón callejero o en una versión más juvenil, el del vándalo infiltrado en manifestaciones sociales, culturales o políticas de la ciudadanía sana.

La única excepción a esta norma la constituye el caso de los que aquí hemos calificado como monstruos, especialmente los pedófilos (como Zacarach) quienes no necesariamente provienen de sectores populares, pudiendo, incluso, pertenecer a sectores acomodados (como el denominado caso Tocornal, en donde el autor de los hechos era un alto ejecutivo bancario).

Por otra parte, la mayoría de los sujetos que aparecen asociados a la comisión de delitos son jóvenes o, cuando más, adultos jóvenes. En efecto, en la mayoría de los casos y muy especialmente en aquellos con mayor impacto sobre la percepción de inseguridad pública, los protagonistas son jóvenes de sexo masculino quienes, desde un punto de vista caracterológico, son presentados siempre como personas violentas e impulsivas, que atacan por sorpresa y, en general, valiéndose de la superioridad numérica. Dichas características se asocian directa o indirectamente a cierta pérdida sobre el control de los impulsos atribuida a la presencia de alguna toxicomanía.

Por lo tanto, la imagen modal del sujeto delincuente promovida por los noticiarios es la de un joven, pobre, violento, impulsivo y toxicómano. Fuera de esta imagen, sin embargo, aparecen otros tipos de sujetos que también se ubican dentro del registro delictivo por lo que parece legítimo preguntarse si existe alguna relación de continuidad entre los distintos tipos de sujeto delincuente identificados.

A nuestro juicio, la respuesta a la anterior interrogante se encontraría en la 
identificación de un rasgo basal que es común a todos los tipos de sujetos delincuentes representados por los noticieros televisivos: la peligrosidad. En formas diversas y de modos heterogéneos, los distintos tipos de sujeto delincuente identificados para este caso son peligrosos, en jerga judicial son "un peligro para la sociedad", es decir, hace emerger el riesgo y, con él, la amenaza y la sensación de inseguridad. Si bien el delincuente, del tipo que sea, siempre es un otro absoluto (connotado negativamente) respecto del nosotros, el problema es que las condiciones bajo las cuales dicha amenaza se actualiza no son posibles de conocer por anticipado, sino que se hacen visibles sólo ex post.

No es poco frecuente encontrar una serie de referencias al pasado de los individuos comprometidos en este tipo de ilícitos, en la búsqueda de hechos que pudieran estar ala base de los comportamientos presentes. Sin embargo, se trata sólo de indicios, hechos que por sí mismos no resultan determinantes y que sólo se vuelven relevantes en una perspectiva retrospectiva, fracasando en la posibilidad de establecer predicciones, con lo que la peligrosidad se muestra como un rasgo insidioso, imposible de anticipar. El único consuelo surge cuando, al revisar dichos antecedentes, nuestras propias biografías aparecen como diferentes (y siempre aparecen, en algún sentido, como diferentes), librándonos del fantasma de que, algún día, nosotros nos transformemos en ellos. 


\section{Capítulo 6 \\ OPERACIONES DISCURSIVAS: FICCIÓN Y REALIDAD EN EL TELENOTICIARIO}

Las operaciones de producción discursiva que subyacen a los telenoticiarios instalan como una dimensión problemática de su constitución la relación entre ficción y realidad. Como señalamos en páginas anteriores, algo característico del discurso periodístico en la sociedad moderna es su pretensión de representar la realidad, es decir, de aquello que es, antes de su significación, por oposición a aquello que no es, sino en el discurso que lo constituye, cuestión que sería exclusiva de la ficción.

En esa dirección, el noticiero televisivo nos indica de manera explícita cómo debemos enfrentarnos a él, esto es como una representación más o menos fiel de la realidad. Sin embargo, en un sentido estricto el noticiario es una fabricación, un artefacto textual, cuestión que lo asemeja a la ficción. Lo que lo distingue es que sus contenidos o temas son los acontecimientos del mundo real. Dicho de otra manera, el noticiero es una narración que dota de sentido a la realidad.

Su acción consiste en contar (narrar) noticias y cada noticia es una narración que impone un orden y un sentido a los sucesos sobre los que trata. La realidad es activamente producida y performativamente interpretada por dispositivos ficticios, jerarquizados y selectivos. Por ello, el noticiero se diferencia de la ficción no en su construcción como texto, sino en las representaciones que hacen uno y otro. En el caso del noticiario, es el propio texto el que nos da instrucciones acerca de su uso y su lectura. Nos pide que lo consideremos como una representación del mundo, en vez de como una semejanza o imitación del mismo. Por otro lado, el noticiero al igual que todo texto tiende a crear un Lector Modelo, es decir, no solamente se apoya sobre una competencia, sino que también contribuye a producirla.

En ese sentido, instruye al telespectador "acerca de cómo se ha de comprender [...], es decir, cómo se ha de leer y percibir. En este sentido, todo telediario es un modelo enciclopédico, un manual de instrucciones de cómo: a) se han de entender las noticias y b) se ha de interpretar todo el telediario" (Vilches, 1989, pp. 76-77). Expresiones como la verdad de los hechos, la realidad aquí en vivo operan como marcadores de diferencia; al decir de Munari (1990), indican el sentido con el que debe asumirse la información dada: no como un texto, sino como la realidad misma. De igual forma, el propio conductor actúa en la misma dirección, aunque al decir de Bourdieu (1997) es la imagen la marca de autenticidad, produciendo efectos de realidad, mostrando y haciendo creer en lo que muestra.

De este modo, se produce en la TV actual un desdibujamiento de los formatos rígidos, haciendo cada vez menos evidentes los límites entre ficción e información. 
En este sentido debe entenderse la noción de flujo televisivo, que indica la pérdida de estabilidad de los géneros televisivos. Los procesos de significación e interpretación no se deducen de los textos considerados en su singularidad, sino del flujo global del discurso televisivo y de los elementos estructurales de aquel: velocidad, variedad, heterogeneidad, que sería lo que hoy es específico de la TV.

Lo anterior se manifiesta en el noticiario televisivo por medio de un conjunto de sus características actuales que generan dicha indefinición de los límites entre ficción e información. Entre ellas cabe mencionar en primer lugar las posibilidades técnicas de edición y montaje, propiamente cinematográficas, junto al eventual uso de actores para recreaciones; el empleo del sonido y la musicalización para generar determinadas atmósferas; el esteticismo de la construcción de planos y los movimientos de cámara, etc.

En segundo término, la relación entre imagen y palabra, lo que permite afirmar que para la TV es noticiable aquello que es audiovisible. La articulación del lenguaje audiovisual con la tecnología informática permite la utilización de un conjunto de recursos propiamente ficcionales, tales como las anacronías en el relato (es decir, no se sigue la lógica lineal del tiempo); el uso de la voz en off(el narrador no es simultáneo con los sucesos, otorgándole un particular protagonismo al reportero de terreno por sobre el conductor en el estudio); el uso de imágenes de archivo que no corresponden al suceso; el uso de dibujos, infografías e imágenes en tercera dimensión, etc.

En tercer lugar y como algo particularmente notorio como tendencia predominante en el periodismo televisivo de los últimos años, la integración de experiencias y sentimientos individuales, de carácter más bien pasional, dentro de una estructura relacional de los hechos. Así, la lógica visual queda supeditada a la lógica del contacto y la proximidad. Cabe señalar que esta tendencia se enmarca en procesos mayores de transformación sociocultural que implican lo que perspectivas como las de Sennett (2002), Lasch (1991) y Lipovetsky (1994) han señalado como el declive de la vida pública y la sicologización y privatización de lo social.

La mencionada lógica del contacto y proximidad se manifiesta, al menos, en tres ámbitos. En primer lugar, en lo espacial: la TV sale a la calle y prácticamente toda información se narra desde el lugar de los hechos, aunque éstos hayan ocurrido en otro momento. Luego, lo que se puede denominar proximidad temática, manifestada en la preocupación por los temas otrora considerados privados (bienestar, relaciones de pareja, sexualidad, salud, etc.) o por la lectura desde lo individual de hechos sociales $\mathrm{y}$, finalmente, por una proximidad discursiva, lo que dice relación con el acercamiento e hibridación de géneros y formatos. En esa perspectiva, el o los presentadores son especialmente importantes en crear la ilusión del contacto y la proximidad, junto a otras estrategias de interactividad (encuestas, llamadas, votaciones, concursos, etc.).

Todo lo anterior es lo que sustenta la operación esencialmente discursiva del telenoticiario que consiste en construir una trama que le de sentido a una serie de acontecimientos, con el resultado que de hecho se elimina una verdadera oposición 
entre ficción y realidad, lo que permite afirmar que el noticiario televisivo se construye desde modelos interpretativos de la realidad, que deben entregar una representación adecuada de ésta.

Al decir del citado Vilches (1989), el noticiario televisivo se construye con segmentos y textos citados de agencias de noticias, de corresponsalías, de centros regionales, de TV extranjeras, etc., los que a su vez también provienen de otras fuentes y materiales, en el sentido que señala Bourdieu (1997) de que los informadores se nutren de otros informadores. De allí surge la estética de la fragmentación que se actualiza diariamente, como en una continuidad sin fin (nadie sabe dónde comienza y dónde termina). La TV se apropia de palabras e imágenes ajenas, las aplica a alguna cosa y termina diciendo algo diferente. Por lo tanto, lo importante no es algún sentido de totalidad, sino, por el contrario, el sentido de continuidad que recibe el espectador.

Por otro lado, aunque resulta obvio para una mirada entendida no está demás recalcar que la TV no es la ventana al mundo, sino un texto audiovisual sobre la realidad visto por la estrecha ventana de la pantalla. Agrega Vilches (1989) que este texto informativo tiende cada vez más a la abstracción y el juego de las formas: pausa y movimiento del VTR; congelamiento de la imagen; ráfagas sintéticas y anagramas digitales; chromakey y presentadores que recitan o leen de otra imagen mientras miran a los ojos; escenarios virtuales, etc.

La información televisiva construye su propia realidad: la realidad televisiva que, insiste el autor, no es sino un texto, entre otras razones por la selección e interpretación que implican las decisiones de encuadre, planos, movimientos y angulaciones de cámara, uso del sonido, etc. Y por la puesta en escena del acontecimiento, no solamente en el estudio, sino que también en el directo, ya que la TV influye en el propio desarrollo del acontecimiento, en la medida en que su sola presencia construye un estudio en cualquier sitio. La puesta en escena del discurso informativo comprende el programa mismo, el lugar que ocupa en la programación, la construcción de los valores informativos y la instalación de los sujetos de la información.

Por otra parte, es necesario insistir en que en la TV el texto verbal no es aislable ni tiene sentido por si mismo. El sentido emerge del discurso audiovisual, es decir de la articulación del texto verbal con la estructura narrativa, la puesta en escena, la complejidad de sucesiones temporales, de secuencias espaciales, etc. El espectador no ve el proceso de construcción discursiva, pero recibe el efecto de sentido que ella porta.

\section{El caso de Canal 13}

En el caso del tratamiento de los hechos por parte de Teletrece, una de las primeras cuestiones generales a resaltar es que las noticias referidas a hechos delictuales no ocupa un lugar preferente dentro de sus prioridades. Como vimos más atrás, tanto en 
número de noticias como en tiempo dedicado aparecen detrás de otros temas como Sociedad, Deporte y Política. Sin embargo, ello no obsta para que esté normalmente presente en los titulares del noticiero. Lo anterior comporta ya una significación importante para el análisis que viene a continuación.

Ahora bien, el ámbito de hechos delincuenciales se presenta en este noticiario amplio y variado. Si bien hay una cierta preeminencia de noticias sobre crímenes y/o homicidios, como muestra el texto antes citado, hay una gran diversidad que puede ir desde sucesos que caen bajo el rótulo de violencia intrafamiliar hasta otros que adquieren la fisonomía del reportaje, en este caso sobre un sector de la ciudad catalogado como uno de los más peligrosos o inseguros. Lo anterior instala un especial sentido al hacer notar que el hecho policial y su protagonista delincuente no constituyen un acontecimiento particular y aislable, sino que se encuentra diseminado por las más diversas prácticas y relaciones sociales y que el lugar del delincuente, en definitiva, puede ser ocupado por cualquiera.

Así, por ejemplo, ocurre con la noticia exhibida el 8 de Enero del 2007 y que da cuenta de como un Coronel (R) de Carabineros dio muerte a "supuestos delincuentes" por robarle su auto. El tratamiento de la noticia instala desde su inicio, el titular es una interrogante “¿Legítima defensa?”, la sospecha frente a lo acontecido, a lo que colabora la expresión supuestos delincuentes y el corolario de la noticia que explica que el victimario fue procesado por homicidio simple. De este modo, en esta noticia vemos como un ex-guardián del orden y la seguridad pasa a ocupar el lugar contrario.

Un segundo caso posible de citar como ilustración es la noticia exhibida en la edición del 13 de Febrero del 2007. Bajo el titular Violencia y Mujeres se narra como una mujer peruana (la mención de su nacionalidad no tiene ninguna vinculación lógica con los hechos) mató de una estocada a su pareja, a raíz de la violencia y los abusos que sufría de parte de esta. En este caso, la noticia coloca clara y explícitamente a la victimaria como víctima ("Es una víctima más de la violencia intrafamiliar"), al poner su caso en el contexto mayor de casos similares ocurridos en esos días ("En las últimas 48 horas, tres mujeres han asesinado a hombres"), lo que se refuerza con el testimonio de la protagonista del hecho y la opinión absolutoria de un Perito Forense de la Brigada de Homicidios y de la Ministra (s) del Servicio Nacional de la Mujer (Sernam), todo ello corroborado por la sentencia del tribunal que decretó su libertad, aunque con medidas cautelares.

En ambas situaciones se nos presentan personas que no forman parte de lo que se puede denominar, según un sentido común masivo, el mundo del delito y que cometieron homicidios, en virtud de un contexto social de inseguridad (robo y violencia intrafamiliar). Ello pareciera estar apuntando a un sentido mayor que el noticiario Teletrece busca instalar, como veremos más adelante.

Por otro lado, la construcción de la noticia tiende a convertir al delincuente o victimario como un lugar importante desde donde surge la operación discursiva que 
articula y da sentido a la información. En ese sentido, su voz muchas veces cobra tanta importancia como la del periodista, las víctimas, los abogados o la policía. Se busca su declaración al ingresar o salir del tribunal y se reproducen trozos de sus testimonios frente a éste. Es el caso de la noticia antes aludida de la mujer que asesinó a su pareja. Así, por ejemplo, en la edición del 26 de Abril del 2007 se informa bajo el título "Juicio a banda" del inicio del procedimiento judicial contra las bandas de Los Guarenes y Los Phillips, que se habían unido para asaltar un camión repartidor de bebidas, a pesar de haber protagonizado incidentes y balaceras entre ellos ("no sólo tienen aterrorizados a los vecinos con sus balaceras"); en este caso, se le concede un espacio importante a la transmisión de un trozo de la audiencia con las declaraciones de los acusados, además de primeros planos, lo que genera un reforzamiento de su imagen de peligrosidad.

De todas formas, el lugar preferente de sujeto de la enunciación lo ocupa el periodista enviado a terreno a reportear los hechos. En ese sentido, el conductor central del noticiero aparece más bien como un elemento que relaciona sus partes e introduce y presenta al narrador principal, que siempre es el reportero que está en el lugar donde se produce la noticia. En su trabajo, puede ocupar diversos roles, ser el narrador omnisciente así como el inquisidor que intenta sacar declaraciones de los acusados.

A lo anterior debe sumarse, como otro elemento importante en la construcción de la noticia policial, el uso de infografías e imágenes virtuales, así como las recreaciones e imágenes de archivo, todos recursos propios de la narración audiovisual como vimos antes que permiten no solamente servir de sustento a la acción del reportero, sino construir visualmente lo que no se vio realmente. Es el caso de la llamada Pistolera de Puente Alto, calificada por el canal como "joven, atractiva y peligrosa”. Se trata de un caso informado en la edición del 14 de Febrero del 2007, en el que una mujer dio muerte a balazos a dos supuestos asaltantes que ingresaron a su casa. Dadas las dudas del tribunal acerca de la versión de la mujer, decidió formalizarla por tenencia ilegal de armas e intento de homicidio y dejarla con arresto domiciliario. Posteriormente, en la edición del 22 de Marzo del 2007 se informaba que dicha mujer había huido de dicha reclusión, dejando una carta que explicaba sus motivos.

En este caso, que cobró bastante notoriedad pública, el noticiario puso en juego todos los recursos narrativos y de construcción discursiva de los que hablamos en páginas anteriores. Las infografías e imágenes virtuales le permitieron recrear las circunstancias del baleo e incluso la escritura de la carta dejada a raíz de su fuga. Dado que el tribunal puso en duda el argumento de la mujer en orden a haber ejercido el derecho a la legítima defensa, el noticiario puso en acción, nuevamente con apoyo de imágenes virtuales, a un conjunto de expertos para tratar de dilucidar en pantalla si la versión de la victimaria era o no creíble. También desfilaron testigos, tanto en el momento de los crímenes como en el de la fuga, todos los cuales contribuyeron a la tesis del noticiario de que la versión de la mujer no resultaba verosímil y que 
más bien todo habría apuntado a que se trataba de un incidente relacionado con el tráfico de drogas. Sentado lo anterior, el texto de la noticia pudo, entonces, trasladar la explicación de los hechos a ese contexto y explicar la acción de la mujer como producto de que "su entorno está marcado por tráfico de drogas y violencia”.

Este caso es uno de los más ilustrativos de cómo el noticiario construye un sentido, sin siquiera tener claridad sobre los hechos que efectivamente ocurrieron, se adelanta a la acción del tribunal, interpreta, sentencia y explica en la perspectiva de un discurso socialmente compartido acerca de la relación delito-drogas.

Hay otro aspecto que parece ser más sustantivo y de fondo a la hora de analizar Teletrece y que dice relación con lo afirmado por Vilches (1989) acerca de la estética de la fragmentación y la continuidad sin fin que serían lo específico del telenoticiario. Como señalamos, en Teletrece normalmente no encontramos lo que se denomina bloque de noticias, en este caso referido a las policiales. Por el contrario, la noticia sobre delitos aparece como una suerte de totalidad en sí misma, fragmento aparentemente desconectado de las otras noticias.

Sin embargo, si se observan los distintos fragmentos noticiosos que componen las diarias ediciones de Teletrece es posible advertir un hilo discursivo que va uniendo a acontecimientos aparentemente muy dispares y ese no es otro que lo que se ha llamado la administración mediática del miedo (Salinas, 2008). En esa dirección, podemos señalar varios ejemplos ilustrativos de lo dicho: en la edición mencionada del 13 de Febrero del 2007, antes de la noticia comentada sobre la mujer que asesinó a su pareja, en un episodio de respuesta a la violencia intrafamiliar, se presentan consabidos reportajes al recién inaugurado Transantiago y, después de ella, se muestra una nota internacional sobre el juicio a los presuntos responsables de los atentados en Madrid y otra nacional sobre la inseguridad que presentarían los ascensores de la ciudad de Valparaíso.

Al día siguiente, cuando se informa el caso de la llamada pistolera de Puente Alto, dicha noticia seguía a las referidas al caos del Transantiago y a otra que refería al accidente carretero sufrido por un camión de seguridad. Más aún, la noticia en cuestión era seguida por otras del siguiente tenor: un reportaje sobre indignas condiciones laborales en China, el ataque de una elefanta furiosa en Sri Lanka, la preocupación por la desaparición de glaciares en los Andes peruanos, el asalto e intento de violación a una conocida actriz nacional en Maullín y una nueva nota sobre el juicio a los acusados por los atentados de Madrid.

En la edición del 22 de Marzo de ese año aparecen dos noticias policiales, la ya aludida acerca de la fuga de la pistolera de Puente Alto de su reclusión domiciliaria y otra que bajo el título "Tribunales inseguros" informa de que uno de los imputados de la banda Los cara de pelota se autoinfirió heridas con una hoja de afeitar en plena realización del juicio oral, con el consiguiente desorden y alboroto (cabe consignar que en pantalla se muestra la imagen del acusado cuando se autoinfiere las heridas 
utilizando cámara lenta y un círculo que destaca la acción). Las dos noticias no van juntas, sino separadas y antecedidas y seguidas por otras que dan cuenta de una emergencia en el Metro vivida por un pasajero que sufrió un paro cardiorrespiratorio a raíz del hacinamiento, destacándose los efectos de stress físico y mental que se viviría a raíz del fracaso del Transantiago; un atentado explosivo en Irak muy cerca de donde se encontraba el Secretario General de las Naciones Unidas y una nota por reclamos contra Fonasa por exigir cheques en garantía a un paciente, lo que implica que no se estaría aplicando la Ley de Urgencias; una noticia sobre la muerte de un trabajador en un accidente ocurrido en la construcción de un túnel carretero en el Cerro San Cristóbal; la perspectiva de sequía en el Norte y dos notas internacionales, una sobre una mujer agredida por policía y otra sobre una operación de rescate de las llamas de accidentados.

En definitiva, el sentido que emerge de esta sucesión de fragmentos noticiosos aparentemente desconectados entre sí es el de un mundo connotado por el miedo, los peligros y la inseguridad para los individuos, de los cuales el hecho delictual es uno más de ellos, aunque probablemente el más temido. Se instala así la percepción de una vida cotidiana amenazada desde todos lados y en el que la seguridad aparece como un bien tan preciado, que justificaría la subordinación de los espacios de libertad y autodeterminación por su aseguramiento. La figura del delincuente no remite, por su lado, a un estereotipo específico de sujeto o actor social, relativamente identificable y por ello, aislable. En la medida en que se vive un entorno marcado por la amenaza del peligro, el delito amenazante puede surgir de cualquier lugar y cualquier persona. Teletrece desarrolla así una operación discursiva estrictamente política, que se inscribe en la perspectiva que exitosamente ha instalado en el sentido común masivo a la seguridad como uno de los principales problemas de la sociedad chilena actual.

\section{El caso de Televisión Nacional de Chile}

El noticiero 24 Horas de Televisión Nacional de Chile presenta algunas características que lo diferencian notoriamente del caso anterior, en lo que se refiere al tratamiento de las noticias sobre delincuencia, aunque desde el punto de vista de la producción periodística televisiva existen obviamente también una serie de operaciones comunes en el plano de la gramática visual, la utilización de recursos informáticos y en el tratamiento de los formatos periodísticos.

La diferencia probablemente más resaltante es el lugar que le concede TVN a las autoridades policiales y judiciales, y secundariamente gubernativas, y su acción contra el delito, mostrando el buen resultado de las políticas del Estado, cuando es posible sustentar dicho juicio con datos empíricos, o al menos su celo y eficiencia individuales. En esa dirección es posible citar un par de casos a manera de ilustración. 
En la edición del 8 de Enero de 2007, bajo la forma de reportaje y con el título de "Confeccionan mapa delictual del sector oriente de Santiago", el portavoz de la Fiscalía Oriente da cuenta de un trabajo de identificación de las principales bandas de delincuentes y sus modos de operar en la zona, así como una tipificación de delitos según los barrios ${ }^{16}$, con apoyo de infografías y testimonios de víctimas y testigos. Asimismo, se informa de los planes y medidas de coordinación tomadas con los Departamentos de Seguridad de las Municipalidades respectivas.

Por otro lado, en la sección estable del telenoticiario llamada Crónicas de la edición del 26 de Abril de 2007, y a propósito de un nuevo aniversario de Carabineros de Chile, se ofrece un reportaje a la Comisaría No 44 de Lo Prado que había recibido el premio a la Mejor Comisaría. El reportaje consistió en que periodistas y camarógrafos del canal acompañaron durante una noche a los policías en su labor de patrullaje y prevención del delito en el sector. Así, se mostraron acciones de control de identidades, control de vehículos motorizados que permitió el decomiso de drogas y otras acciones. Se resaltaban los peligros propios de la actividad policial y el compromiso de los carabineros con su trabajo, a pesar de lo anterior y de las bajas remuneraciones que reciben. El reportaje finaliza con la ceremonia de premiación a la Comisaría distinguida en La Moneda, con la presencia de las autoridades de la institución, la Presidenta de la República y el Ministro de Defensa.

Además de lo anterior, que constituyeron casos relativamente especiales, dado que es la acción oficial sobre el delito lo que constituye la noticia, más que un hecho delictual, en todas las notas sobre hechos policiales se resalta no solamente la opinión de fiscales, abogados o policías y otras autoridades, sino que constituyen una opinión clave y aparecen siempre desde un lugar de eficacia y respetabilidad.

Un segundo elemento de diferenciación dice relación con el hecho de que la noticia policial no es parte de un bloque o sección especial del telenoticiario, cuestión que sí se usa para las noticias relacionadas con la actividad deportiva por ejemplo, y, sobre todo, que no es un fragmento más de una cadena de hechos de inseguridad, sino que es tratada como un caso específico y aislado. Esto último va acompañado de un tratamiento periodístico más completo y de una cobertura más amplia en algunos casos.

Ejemplo de lo anterior es el tratamiento que se le dio al caso de la llamada Pistolera de Puente Alto, ya citado antes. El hecho aparece por primera vez en la edición de mediodía del 13 de Febrero de 2007, donde la explicación central de lo sucedido está

\footnotetext{
16 En ese sentido, se señala que en el sector de Alonso de Córdova con Nueva Costanera predominan los robos y asaltos a tiendas y a los trabajadores de ellas; en centros comerciales como Alto Las Condes y Parque Arauco el hurto simple y los llamados mecheros, que roban mercaderías de las tiendas; por su parte, en Av. Vitacura con Nueva Costanera son mayores los robos a vehículos estacionados y en los sectores de La Dehesa y Colón los asaltos a casas, constituyéndose en los puntos con mayor ocurrencia de delitos en el sector.
} 
a cargo del Fiscal de Puente Alto y un Subcomisario de la Policía de Investigaciones. Esta nota es más bien breve, dada la cercana ocurrencia de un suceso que no presenta un cariz totalmente claro. Ese mismo día, sin embargo, en la edición nocturna hay una cantidad de material visual y verbal mucho mayor que el de otros canales. Por de pronto, hay un primer plano de la victimaria y un breve testimonio de ella al momento de ser detenida ("estoy amenazada"). El primer plano que se ofrece destaca a una mujer de carácter que no manifiesta inseguridad o debilidad en su actitud y expresión. Se entregan mayores detalles del hecho por parte del periodista señalando que "vació dos cargadores" sobre los supuestos asaltantes a su domicilio y que a uno le disparó en las piernas y luego lo remató en el suelo. Asimismo, se entregan testimonios de vecinos ("defendió a sus hijos") y de una tía de la imputada ("lo hizo por sus hijos"), además de nuevas explicaciones a cargo de otro Comisario de la Policía de Investigaciones.

Aldía siguiente se le hace un seguimiento al hecho con una nota que trata de indagar más a fondo sobre los aspectos que presentan mayores interrogantes del caso. La conductora del noticiero justifica la presencia de la nota ("gran impacto de la historia de ayer sobre la joven madre") y se plantean una serie de dudas como la posibilidad de que hubiera habido cómplices. Se entrevista a un experto en armas y toma la palabra nuevamente el Fiscal de Puente Alto. A la victimaria se le da protagonismo esta vez no por sus palabras, sino a través de un tratamiento puramente visual por medio de una imagen de ella en el tribunal mirando de soslayo a la cámara y luego por un plano que recorre su atractiva figura cuando abandona el tribunal.

Posteriormente, en la edición del 22 de Marzo de 2007 se informa de la fuga de esta joven de la reclusión domiciliaria a la que estaba sometida, para ello se realiza una recreación actoral del hecho y se usan infografías para dar cuenta de la carta que ella había dejado y nuevamente la explicación central está a cargo del mismo Fiscal.

En este como en otros casos 17, el sujeto preferente de la enunciación tiende a ser la autoridad (judicial o policial), más que el periodista que está en terreno reporteando el acontecimiento. Incluso, a diferencia de otros canales, como es el caso de Teletrece, los conductores del noticiero juegan un rol más activo interviniendo en el despacho en vivo con preguntas e incluso comentarios, como cuando el reportero está informando sobre el caso de la Pistolera de Puente Alto, ella irrumpe con la pregunta de si "¿fue legítima defensa?", para luego sentenciar, "eso lo deberá determinar la Justicia”. En ese sentido, la acción de TVN no intenta convertirse en una suerte de tribunal que investiga, interroga, juzga y sentencia, sino más bien intenta otorgarle una suerte de voto de confianza a la acción del Estado y sus personeros.

17 Como por ejemplo en el caso de un ejecutivo acusado de realizar abusos sexuales a sus hijos, informado también en la edición del 22 de Marzo de 2007. 


\section{El caso de Chilevisión}

Desde todo punto de vista, Chilevisión es el canal que más importancia da al tema de la delincuencia dentro de su telenoticiario tanto en términos absolutos como en términos relativos. En términos absolutos, porque Chilevisión es el canal que mayor tiempo promedio dedicó diariamente, durante el período de la muestra, al tratamiento del tema de la delincuencia con un promedio de 4 minutos y 4 segundos y una moda de 3 noticias por emisión (cada una de las cuales posee una duración que oscila entre 1 minuto 10 segundos y 3 minutos 4 segundos, encontrándose la moda en torno a los 2 minutos). En términos relativos porque Chilevisión otorga una ubicación privilegiada a esta temática: en general la emisión se inicia con este tipo de noticias y, generalmente, al menos una de las que se va a abordar forma parte de los titulares; por otra parte, es virtualmente el único noticiero que posee un segmento específico dedicado al tema lo que se traduce en que, habitualmente, las distintas noticias relacionadas con hechos delictivos sean emitidas juntas, aún cuando este es un hecho que admite algunas excepciones entre emisiones.

No obstante lo anterior, es necesario aclarar que, incluso en este caso, desde el punto de vista de la cobertura, el tema de la delincuencia y del sujeto delincuente se ubica sólo en el tercer lugar en relación con otras áreas temáticas, muy por detrás de Sociedad y Cultura (que posee una moda de 8 noticias por emisión para el período estudiado) y de Deportes (que posee una moda de 6 noticias para el período estudiado).

Por otra parte, si se considera específicamente el tipo de hechos que se aborda en las notas dedicadas el tema de la delincuencia, puede observarse que el mayor interés se concentra en la categoría "crímenes u homicidios" que para el período estudiado exhibe un promedio de 1 noticia por emisión, seguida a bastante distancia de aquellas notas en las que se abordan temas generales dedicados al "sistema judicial" con un promedio de 0,4 noticias por día (categoría que no ocupa un lugar relevante en ninguno de los demás noticieros), seguidas en un mismo nivel por aquella notas dedicadas a "robos y/o asaltos a personas", "robos a empresas" e "incivilidades", todas con un promedio de aparición de 0,3 noticias por emisión. La concentración de las noticias en torno a dichas categorías da clara cuenta del privilegio dado por la estación a los delitos de carácter violento y, muy especialmente, a aquellos en los que la violencia se dirige contra las personas. En este aspecto, un punto al que se le presta gran atención dentro del noticiario es a los llamados "crímenes pasionales", relacionados con el fenómeno general de la violencia intrafamiliar y, más específicamente, con la violencia contra las mujeres con resultado de muerte, conceptualizada bajo la idea del femicidio.

Ahora bien, desde un punto de vista más cualitativo, el tratamiento dado a las 
noticias dedicadas al tema de la delincuencia por Chilevisión es bastante característico y podría ser calificado básicamente como "polifónico" por el número de voces que se hace intervenir en cada noticia y las diversas posiciones que cada una de ellas representa. Un ejemplo que ilustra bien esta situación es el de la noticia emitida el 13 de febrero y que da cuenta del caso de una mujer de 27 años que acribilló a dos jóvenes que entraron a su domicilio supuestamente a robar (caso que será conocido posteriormente como el de la mujer pistolera); además de la presentadora (que da un primer acercamiento a la noticia, proponiendo la perspectiva desde la que debe ser leída) y del periodista que cubre la noticia (y que se presenta siempre en off, como un relator omnisciente) intervienen la propia imputada, un comisario de la Brigada de Homicidios de la Policía de Investigaciones de Chile (2 veces), un joven vecino del sector (que especula sobre la procedencia de los delincuentes abatidos), una mujer adulta vecina del sector (quien se queja del abandono del sector y de las represalias a las que están expuestos por dar declaraciones u oponerse a los delincuentes) e incluso el hermano de la imputada (quien protagoniza un altercado con los periodistas).

En la continuación de esta noticia, emitida el día 22 de marzo y en la que se aborda la fuga de la imputada desde el arresto domiciliario al que había sido sometida por el tribunal, a las anteriores voces se agregan las de la hermana, las de otro familiar de la imputada, las de la fiscalía, las de un vecino próximo al lugar donde cumplía su arresto domiciliario y la de una de las madres de los asesinados, quien pide justicia. De esta forma, podemos apreciar que en la construcción del relato noticioso aparecen, en diversos momentos y dependiendo de las características específicas del hecho, los siguientes tipos de actores:

a. Los imputados o sus allegados (familiares o amigos)

b. Las víctimas o sus allegados (familiares o amigos)

c. Las policías (Carabineros e Investigaciones)

d. Los fiscales

e. Los defensores (públicos o privados)

f. Testigos directos o indirectos

g. Informantes clave (vecinos u otras personas que entregan testimonios acerca de las características personales de los imputados o las víctimas o datos acerca del entorno social en el que se desarrollaron los hechos)

h. Expertos (psicólogos, psiquiatras, médicos, criminólogos, etc.)

Desde este punto de vista, podríamos decir que Chilevisión Noticias es un telenoticiario que se muestra preocupado de la "objetividad" de sus notas o, mejor dicho, por la "equidistancia”, entendida ésta última como la inclusión de la mayor cantidad de perspectivas posibles respecto de un hecho sin privilegiar ninguna por sobre otra.

Sin embargo, además del número de voces intervinientes, llama también la atención que se promueva una especie de fusión entre la voz del canal (representada 
por los periodistas) y la voz de los agentes sociales que intervienen en ella y muy especialmente de aquellos que representan a la Ley y/o al Estado, ya sea por el expediente de que los periodistas continúen las palabras iniciadas por estos agentes o, a la inversa, que se utilicen expresiones de los entrevistados para rematar una idea previamente perfilada por el periodista lo que, obviamente, genera una complicidad (expresada como mutua apoyatura) entre dichas voces, dándoles un privilegio que relativiza la supuesta preocupación por la "objetividad" y la "equidistancia”.

Otro elemento que llama la atención es el lugar central ocupado por el sistema judicial, y muy especialmente por los tribunales de justicia, en la organización del relato noticioso. Es común que la mayoría de estas noticias se inicie con los imputados llevados hacia el espacio de la sala de audiencias y concluya con la imagen de los mismos imputados haciendo abandono de ella. Dada su trascendencia en relación con el objetivo final de este trabajo, volveremos sobre ambos puntos más adelante. Lo relevante para este caso es que en la presentación de los hechos vinculados a la delincuencia, Chilevisión asume un papel institucional que no es el del gobierno y, ni siquiera, el de los Tribunales de Justicia, es el de la sociedad o, más precisamente, el del orden social: la delincuencia es presentada como aquello que agrede el orden social.

Una serie de operaciones discursivo-retóricas se encuentran comprometidas en el logro del efecto de veridicción que se busca dar a las noticias en este telenoticiario.

Una primera operación tiene que ver con el rol que juega el presentador del noticiero en relación con el reportero en terreno: casi toda la carga propiamente informativa la lleva este último, reservándose para el primero la gestión de la función fática del leguaje (esto es, el control del contacto y la relación con las audiencias) y, en algunas ocasiones, la realización de algunos comentarios sobre los hechos informados (rol que era ejecutado más frecuentemente por Alejandro Guillier que por el resto de los presentadores), las que siempre expresan una suerte de sentir popular y coinciden con cierto sentido común medio.

En relación con el rol de los presentadores, éstos generan el metacontexto que se propone para la lectura-interpretación de la noticia mediante expresiones del tipo "cambiando de tema” o "en el mismo ámbito" (según se quiera establecer continuidad o quiebres con lo anterior), "un horrendo parricidio o un episodio extraño" (a fin de introducir el contenido de la nota y disponer emocionalmente al auditorio) o "espérenos un momentito y ya volvemos" (para evitar que el contacto se interrumpa durante los comerciales). El reportero en terreno, por su parte, presenta los antecedentes, describe los hechos, entrevista a los involucrados e, incluso en algunas ocasiones, aclara las dudas que pudiera tener el propio presentador quien, para estos efectos, ocupa el lugar del público.

Lo anterior genera la impresión que la noticia procede, directamente y sin intermediaciones, desde lugar de los hechos siendo el rol del telenoticiero el de reproducirla tal y como ella se ha presentado, oscureciendo todos los elementos 
narrativos y de postproducción que se encuentran presentes en ella y que le dan su sentido último de completitud.

Un segundo tipo de operación, perfilada ya en el análisis del tratamiento de las noticias relativas al sujeto delincuente, tiene que ver con la forma en que se utilizan las declaraciones de los involucrados. Hemos dicho que, en el tratamiento de las noticias, pareciera existir una preocupación explícita por la "objetividad" y "equidistancia" expresada en la inclusión del mayor número de voces posibles en torno a un determinado hecho. Sin embargo, hemos señalado también que es habitual que se tomen fragmentos de los dichos de algunos de los actores considerados y muy especialmente de aquellos que representan al Estado (básicamente policías y fiscales) intercalándolos con la voz del narrador para ir hilvanando el relato de la noticia: de esta forma, algunas oraciones de los fiscales o policías son rematadas por la voz del periodista y viceversa.

Lo anterior genera una evidente complicidad con esas voces, que las dota de cierta primacía respecto de otras que también pudieran incluirse, las que quedan relegadas a una visión periférica o, a lo menos, no institucional. Sin embargo, no se trata sólo de una solapada forma de tomar partido frente a determinados hechos, se trata más bien de toda una estrategia que tiende a disolver la diferencia entre la voz de estos agentes y la del propio canal, superponiendo intereses que son discontinuos y generando la sensación que el noticiero se limita a reproducir lo "dicho por otros", en circunstancias que está implicado en un proceso de profunda construcción de la noticia y sus dimensiones. Mediante esta estrategia y al ser esos "otros" con los que se produce la operación de fusión, representantes de poderes del Estado, se materializa una primera operación de captura de lo institucional en lo mediático.

Un tercer tipo de operación discursiva, también perfilada en el análisis del tratamiento, la representa la forma en que se introduce el espacio de los Tribunales de Justicia en la construcción de la noticia. Indudablemente, los Tribunales son el lugar social donde se relatan los hechos investigados, se presentan las evidencias y se establece una cierta verdad jurídica que, posteriormente, es sancionada por los jueces mediante la dictación de la sentencia (de culpabilidad o inocencia) y, finalmente, por medio del establecimiento de la pena específica, cuando ello corresponde.

Dado esto, el hecho que las noticias habitualmente (y cuando ello es posible) comiencen con los imputados ingresando a las salas de audiencia y se cierren con los mismos imputados abandonando dichas salas, representa una operación discursiva de primera importancia puesto que, por medio de ella el canal logra, no ya camuflar su propia voz haciéndola aparecer como si fuera la voz de un tercero, sino hacer aparecer al propio noticiero como un espacio jurídico o, más bien, como un dispositivo jurídico-mediático donde, de cara a la sociedad, se establecen los hechos, se ponderan los antecedentes, se juzga y se establece una verdad o, mejor dicho, la verdad. En efecto, cuando las noticias referidas a delitos comienzan y finalizan de esta forma, generan un 
espacio dentro del cual queda simbólicamente atrapado el sistema judicial, pasando a hacer las comparecencias y la presentación de las pruebas y argumentos no sólo ante el juez sino ante toda la sociedad (obviamente, de un modo abreviado y siempre bastante parcial).

De hecho, muchos recursos se ponen, de un modo heterogéneo y no siempre sistemático, al servicio de este propósito: por lo pronto las declaraciones de la mayor cantidad posible de involucrados, las imágenes de eventuales evidencias (manchas de sangre, casquillos de bala, armas envueltas en bolsas plásticas, fotografías de las víctimas, entre otras), infografías ad-hoc y, muy especialmente, recreaciones de los hechos.

Este último recurso, utilizado muy frecuentemente por Chilevisión Noticias, resulta especialmente interesante dado su carácter marcadamente retórico. Un claro ejemplo lo encontramos en la noticia emitida el día 20 de marzo, en la que se aborda la segunda jornada del juicio oral contra una banda de secuestradores express (es decir, secuestradores que en un lapso breve de tiempo intentan sacar el máximo dinero posible a sus víctimas) conocida como la Banda del Guatón Lucho. En este caso, luego del relato que las propias víctimas realizan ante el tribunal, la nota muestra una recreación del instante en que una de ellas es secuestrada por la banda y es conducida hacia la casa en que será retenida por varias horas. La recreación, en sí misma, aporta muy poco material visualmente relevante: los actores son mostrados sólo de la cintura para abajo y se los ve sólo arrastrando a una persona hacia una camioneta blanca que se aleja por un camino de tierra; la escena se encuentra grabada con cámara subjetiva lo que le resta aún más nitidez al conjunto. Misma cosa ocurre con el caso de la noticia emitida el día 25 de abril, en la que se informa de la detención de un suboficial en retiro de la armada acusado de abusar sexualmente de sus hijos, un sobrino y del hijo de un amigo: en este caso, luego de mostrar al hombre siendo conducido hacia un vehículo policial por dos detectives, se muestra una recreación en la que se observa a un hombre que camina con un niño hacia un parque de juegos, escena que es presentada mediante tomas difuminadas y lejanas que impiden la identificación del rostro de los actores; nuevamente, el fragmento no entrega ningún tipo de información específica sobre el caso en cuestión. En ambos ejemplos, el propósito último pareciera ser dar vivídez al relato periodístico, estimulando la imaginación de los telespectadores de modo que vayan completando por sí mismos estas escenas en el sentido propuesto.

El actor que une los distintos elementos y los transforma en un relato coherente es, evidentemente, el reportero en terreno quien, para estos efectos, adopta siempre la posición del narrador omnisciente que, desde una perspectiva panóptica, es capaz de ver los hechos del pasado, adelantar los del futuro e, incluso, adentrarse en la motivaciones e intenciones de los actores involucrados en los hechos. La cuestión de las motivaciones representa un elemento clave dentro de este ejercicio de coherenciación, puesto que permite establecer el sentido final para las conductas 
de los involucrados. Por ejemplo, en el caso de la noticia de la llamada mujer pistolera y en relación con la forma en que ocurrieron los sucesos, el periodista que cubre los hechos señala: "aparentemente Caroleyn esperó a que los individuos entraran a su casa para acribillarlos”. Adviértase cómo en esta breve y, a primera vista, ingenua afirmación no sólo hay una descripción de los sucesos, también hay una hipótesis respecto de las motivaciones últimas que habría tenido la inculpada: ella no se habría visto sorprendida por los individuos ni se habría visto forzada por la circunstancias a actuar de la forma en que lo hizo, muy por el contrario, esperó deliberadamente a que ingresaran a su domicilio con la intención de acribillarlos, esto es, se dio cuenta que había personas que intentaban ingresar a su domicilio y no trató de disuadirlos para que huyeran sino que los dejó entrar para asesinarlos, por lo tanto, no se trata de legítima defensa sino, más bien, de un ajuste de cuentas.

El conjunto de estos recursos retóricos (establecimiento del espacio mediático como un espacio jurídico, disposición de pruebas y antecedentes y unificación en el relato de un reportero-narrador-omnisciente) permiten al telenoticiario capturar, imaginariamente, el lugar social de la justicia, anticipándose al resultado del proceso.

\section{El caso de Megavisión}

Meganoticias ocupa el segundo lugar, tanto en términos absolutos como en términos proporcionales, en lo que se refiere a cobertura de noticias vinculadas con delitos: en términos absolutos, el tiempo promedio dedicado a este tipo de noticias por el noticiero central de Megavisión fue de 4 minutos 17 segundos ligeramente al frente de los 4 minutos 0 segundos dedicados por Teletrece a este mismo tema (y ambos por detrás de los más de 7 minutos diarios que le dedica Chilevisión Noticias); en términos proporcionales, la inicialmente leve diferencia con Teletrece se profundiza debido a que Meganoticias es bastante más breve que el resto de sus competidores ( 15 minutos menos de duración promedio) por lo que sus 4 minutos 17 segundos promedio representan más del 14\% del total de su duración, mientras que los 4 minutos promedio de Teletrece equivalen sólo a un 8,5\% del total.

Dicho lo anterior, no obstante, debe aclararse que la cobertura de Meganoticias a este tipo de noticias es bastante menos sistemática que la entregada por Chilevisión, por ejemplo, no siendo incluso poco frecuente la existencia de emisiones en las que el tema de la delincuencia no es abordado en absoluto, mientras que en otras se le dedican reportajes de varios minutos $(5$ o 6) e, incluso, entre una emisión y otra se hace seguimiento de la evolución judicial de las noticias.

En lo que Meganoticias no difiere de los otros noticiarios es en que la cobertura dada a los temas relacionados con la delincuencia y el sujeto delincuente ocupan sólo el tercer lugar en relación con otras áreas temáticas con sólo 2 notas diarias en 
promedio, muy por detrás de Sociedad y Cultura, con 5 notas diarias promedio, y Deportes, con 3 notas diarias promedio.

Ahora bien, dentro del área de la delincuencia, la cobertura dada por Meganoticias a los distintas categorías de noticias es mucho más homogénea que la observada en los demás canales puesto que si bien la categoría "crímenes y/u homicidios" es la que mayor atención recibe (con un promedio de 0,5 notas diarias), su diferencia con las demás categorías cubiertas no es tan marcada como en el caso de otros canales (como Chilevisión o Canal 13), distribuyéndose todas ellas homogéneamente con un promedio de 0,2 notas diarias. Estos otros ámbitos que reciben atención por parte de Meganoticias son: "delitos sexuales", "robos y/o asaltos a personas", "robos a empresas", "tráfico y/o consumo de drogas" e "incivilidades”. En conjunto, el panorama refleja un interés privilegiado por los delitos violentos ya sea que esa violencia se dirija hacia las personas o, más genéricamente, hacia la sociedad en su conjunto (como ocurre en el caso de las "incivilidades").

Aunque mantiene ciertos elementos de continuidad con la forma en que otros noticiarios trabajan las noticias relacionadas con la delincuencia y el sujeto delincuente, Meganoticias posee ciertas especificidades. En primer lugar, el número de voces intervinientes en la construcción de la noticia es bastante limitado en comparación, por ejemplo, con lo que ocurre en Chilevisión Noticias. En las distintas notas revisadas durante el período puede observarse que se da un privilegio mayoritario a las voces oficiales, especialmente las de las policías y la fiscalía, matizadas sólo en algunas ocasiones por las de las víctimas, esto último especialmente cuando se detecta lo que se consideran fallos en la aplicación de la justicia o bien una aplicación demasiado "suave" de las medidas preventivas o de las penas.

A este respecto resulta destacable también que, a diferencia de lo que ocurre en otros canales, la narración utilizada para la presentación de las noticias considera la utilización de juicios mucho más categóricos tanto en torno a los hechos delictivos como en torno a los sujetos que los protagonizan y las motivaciones que los guían. Desde este punto de vista, más que cuidar una imagen de objetividad (incluyendo muchas visiones que complejicen el fenómeno), Meganoticias toma desde un inicio una posición clara contra los delincuentes y a favor de las víctimas, alineándose desde un comienzo con lo que entiende como sentido común ciudadano en esta materia

Un claro ejemplo de ello lo encontramos en la noticia emitida con fecha 26 de abril en la que bajo el titular "Desarticulan peligrosa banda de asaltantes de farmacias" se informa la captura por parte de Carabineros de tres menores de edad que, presuntamente, habían protagonizado varios asaltos a farmacias del centro de Santiago. La narración de la noticia va apoyada por imágenes obtenidas desde las cámaras de seguridad de las farmacias asaltadas en las que se puede observar a tres individuos que ingresan armados, amenazan a los dependientes y al público, saltan por sobre el mostrador y se apoderan de la recaudación allí existente, así como de fotografías de 
los rostros de los tres menores en los que únicamente aparecen distorsionados los ojos. A continuación se observa el testimonio del oficial de Carabineros a cargo de la investigación de los hechos y luego imágenes del allanamiento de los domicilios de los menores y su posterior detención. Durante la nota se pone especial énfasis en que el menor de 15 años que supuestamente lidera esta banda y que es apodado El cebolla habría comenzado a delinquir a los 11 años y a la fecha registraría 49 detenciones, siendo un peligroso delincuente habitual que se beneficiaría de las penas atenuadas y las medidas menos restrictivas que recibe en virtud de su condición de menor de edad, las que aprovecharía (deliberadamente) para continuar delinquiendo, lo cual es refrendado mediante declaraciones del fiscal a cargo del caso.

Al día siguiente, el noticiario comienza con un seguimiento de la evolución de dicha noticia en la cual, bajo el expresivo titular de "Se acabó el festín para la banda de El Cebolla”, se informa que los menores detenidos el día anterior habían quedado en prisión preventiva por orden del tribunal y a pesar de ser menores de edad, en atención a que representarían un "evidente peligro para la sociedad". Durante la narración de los hechos se califica insistentemente a los menores de antisociales y se destaca el hecho que actuarían con descaro y de un modo claramente concertado. Se afirma, además, que considerando que El cebolla comenzó a delinquir a los 11 años no es raro que a la fecha registre 59 detenciones ( 10 más que las que se le atribuían sólo 24 horas antes) y que, contrario a lo que afirman las tesis más proteccionistas (que, obviamente, no son representadas), se trata de individuos que saben distinguir perfectamente entre el bien y el mal, por lo que deben estar tras las rejas. No puede dejar de mencionarse el ambiente general de triunfo que atraviesa la noticia y que está expresado en la idea que gracias a la atención que el noticiario dio al caso se logró el merecido y necesario endurecimiento de las medidas cautelares.

Puede apreciarse cómo en la anterior noticia predomina una visión represiva y punitiva en torno a la figura del delincuente y del combate a la delincuencia, que concibe el tratamiento de este problema fundamentalmente desde una perspectiva policial, pasando su solución, finalmente, por el encarcelamiento de los delincuentes. En relación con esta visión, la forma en que se construye el argumento no admite ningún tipo de disidencia, coincidiendo con él desde los agentes del Estado hasta el propio presentador.

Coincidente con lo anterior, el recurso visual más utilizado por Meganoticias en la presentación de este tipo de noticias son las imágenes de cámaras de seguridad que muestran a los delincuentes en acción y que son mostradas una y otra vez a fin de dejar suficientemente establecido cuáles son las consecuencias que se siguen de que este tipo de sujeto goce de la libertad. 


\section{REFERENCIAS BIBLIOGRÁFICAS}

Baudrillard, J. (1993). La ilusión del fin. La huelga de los acontecimientos. Barcelona: Anagrama.

Baudrillard, J. (1991). La Guerra del Golfo no ha tenido lugar. Barcelona: Anagrama. Bourdieu, P. (1997). Sobre la Televisión. Barcelona: Anagrama.

Blackman, L. y Walkerdine, V. (2001). Mass hysteria. Critical psychology and media studies. Nueva York: Palgrave.

Casasus, J. y Núñez, L. (1991). Estilo y Géneros Periodísticos. Barcelona: Ariel Comunicaciones.

Charnley, M. (1971). Periodismo Informativo. Buenos Aires: Troquel.

Chiricos, T., Padgett, K. y Getz, M. (2000). Fear, TV news and the reality of crime. Criminology, 38(3), 755-786.

Consejo Nacional de Televisión [CNTV] (2005). Barómetro de Calidad: Noticieros Centrales de la Televisión Abierta. Santiago: CNTV.

Consejo Nacional de Televisión [CNTV] (2003). Estudios de audiencia y consumo televisivo 1999-2002: Televisión y Centros Urbanos. Televisión y Adolescentes. Consumo y Valoración de Noticiarios. Los Chilenos y la Regulación de la Televisión. Santiago: CNTV.

D’Adamo, O. y García, V. (2003). Índice de violencia social percibida: comparación de los delitos reales cada 100 mil habitantes en los años 2000, 2001 y 2002 y la evolución de la inseguridad según los medios gráficos de Argentina en el mismo período. Buenos Aires: Centro de Opinión Pública de la Universidad de Belgrano.

Dastres, C., Spencer, C., Muzzopappa, E. y Sáez, C. (2005). La construcción de noticias sobre seguridad ciudadana en prensa escrita y televisión. ¿posicionamiento, distorsión o comprensión?. Santiago: Centro de Estudios en Seguridad Ciudadana, CESC, Universidad de Chile.

Dastres, C. (2003). ¿Visiones personales, ideología o mercado al momento de informar? Un análisis de las noticias sobre inseguridad ciudadana desde el emisor. Santiago: Centro de Estudios en Seguridad Ciudadana, CESC, Universidad de Chile.

De Fontcuberta, M. (1993). La Noticia. Pistas para percibir el mundo. Barcelona: Paidós.

Ema, J., García, S. y Sandoval, J. (2003). fijaciones políticas y trasfondo de la acción: movimientos dentro/fuera del socioconstruccionismo. Revista Política y Sociedad, 40(1), 71-86.

Filippi, E. (1973, Noviembre-Diciembre). Editorial Revista Ercilla 2000 Semanas (Edición extra). 
Foucault, M. (1996). Tecnologías del yo. Barcelona: Paidós.

Foucault, M. (1991). Microfísica del poder. Madrid: La Piqueta.

Garaycoechea, Ó. (1997, Noviembre 28). Formatos de información televisiva. La Nación.

Gergen, K. (1996). Realidades y relaciones. Aproximaciones a la construcción social. Barcelona: Paidós.

Gil Calvo, E. (2003). El miedo es el mensaje. Riesgo, incertidumbre y medios de comunicación. Madrid: Alianza.

Gomis, L. (1991). Teoría del Periodismo. Cómo se forma el presente. Barcelona: Paidós.

Kuhn, T. (1971). La estructura de las revoluciones científicas. México D.F.: Fondo de Cultura Económica.

Klapper, J. (1960). Efectos de las comunicaciones de masas. Poder y limitaciones de los medios modernos de difusión. Madrid: Aguilar.

Lasch, C. (1991). La cultura del narcisismo. Santiago: Editorial Andrés Bello.

Lipovetsky, G. (1994). El crepúsculo del deber. Barcelona: Anagrama.

Mattelart, A. y Mattelart, M. (1974). La Comunicación masiva en procesos de liberación. México D.F.: Siglo XXI.

Mattelart, A. y Mattelart, M. (1970). La ideología de la prensa liberal en Chile. Santiago: Cuadernos de la Realidad Nacional No 3 - CEREN.

McCombs, M. y Shaw, D. (1972). The agenda setting function of mass media. Public Opinion Quarterly, 36(2), 176-187.

Moscovici, S. (1971). Psicoanálisis, su imagen y su público. Buenos Aires: Huemul.

Munari, A. (1990). ¿De verdad o de mentira?. En VV.AA., Videoculturas de fin de siglo. Madrid: Cátedra.

Noelle-Neumann, E. (1984). La espiral del silencio. Opinión pública: nuestra piel social. Barcelona: Paidós.

Ossandón, C. y Santa Cruz, E. (2001). Entre las alas y el plomo. La gestación de la prensa moderna en Chile. Santiago: Arcis-LOM.

Pearce,B. (2005). Nuevos modelosy metáforas comunicacionales: el pasaje dela teoría a la praxis, del objetivismo al construccionismo social y de la representación a la reflexividad. En Fried, D. (Ed.), Nuevos paradigmas, cultura y subjetividad (pp. 265-283). Buenos Aires: Paidós.

Potter, J. (1998). La representación de la realidad. Discurso, retórica y construcción social. Barcelona: Paidós.

Potter, J. y Wetherell, M. (1987). Discourse and social psychology. Londres: Sage. Puente, S. (1997). El drama hecho noticia. Santiago: Universidad Católica de Chile.

Ramos, M. y Guzmán, J.A. (2000). La guerra y la paz ciudadana. Santiago: LOM.

Rodrigo Alsina, M. (1996). La construcción de la noticia. Barcelona: Paidós.

Rorty, R. (2001). La filosofía y el espejo de la naturaleza. Madrid: Cátedra. 
Rorty, R. (1990). El giro lingüístico. Barcelona: Paidós.

Rose, N. (1998). Inventing our selves. Psychology, power and personhood. Cambridge: University Press.

Sacks, H. (1992). Lectures on conversation. Oxford: Basil Blackwell.

Salinas, C. (2008). La seguridad y la administración mediática del miedo. El delito en los editoriales de El Mercurio y La Tercera. Tesis para optar al grado de Magíster en Comunicación Política, Universidad de Chile, Santiago.

Santibáñez, A. (1974). Periodismo Interpretativo. Santiago: Andrés Bello.

Searle, J. (1997). La construcción de la realidad social. Barcelona: Paidós.

Sennett, R. (2002). El declive del hombre público. Barcelona: Península.

Sunkel, G. (2000). Libertad de expresión: otra transición pendiente. En O. Corrales y J. Sandoval (Eds.), Psicología política: cambio cultural y participación social. Valparaíso: Ediciones Universidad de Valparaíso.

Torres, L. (1975). La Información y el mensaje periodístico. Santiago: Escuela de Periodismo, Universidad Católica de Chile.

Van Dijk, T. A. (1996). La Noticia como discurso. Barcelona: Paidós.

Verón, E. (1971). Lenguaje y Comunicación Social. Buenos Aires: Nueva Visión.

Vilches, L. (1989). Manipulación de la información televisiva. Barcelona: Paidós.

Voloshinov, V. (1992). El marxismo y la filosofía del lenguaje. Madrid: Alianza.

Wittgenstein, L. (1988). Investigaciones filosóficas. Barcelona: Crítica.

Wolff, M. (1987). La investigación de la Comunicación de Masas. Barcelona: Paidós. 